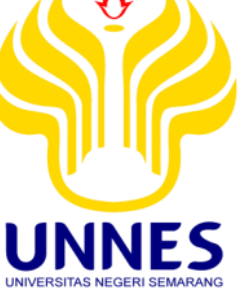

\title{
KESENIAN GAMBANG KROMONG DI PERKAMPUNGAN BUDAYA BETAWI SETU BABAKAN JAKARTA SELATAN : KAJIAN SEJARAH DAN ENKULTURASI
}

\author{
SKRIPSI \\ untuk memperoleh gelar Sarjana Pendidikan \\ oleh \\ Nama : Marissa Renimas Harlandea \\ NIM $\quad: 2501412024$ \\ Program Studi : Pendidikan Seni Drama Tari dan Musik \\ Jurusan $\quad$ : Pendidikan Seni Musik
}

FAKULTAS BAHASA DAN SENI UNIVERSITAS NEGERI SEMARANG 2016 

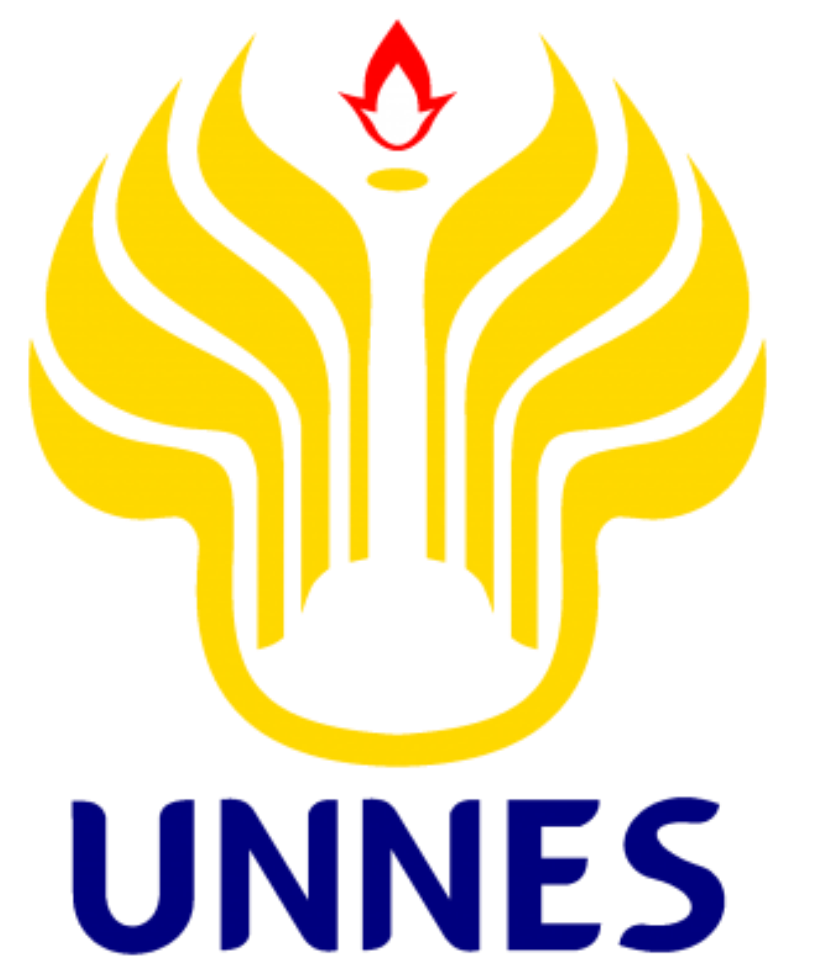

UNIVERSITAS NEGERI SEMARANG 


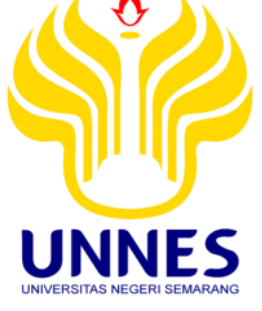

\section{KESENIAN GAMBANG KROMONG DI PERKAMPUNGAN BUDAYA BETAWI SETU BABAKAN JAKARTA SELATAN : KAJIAN SEJARAH DAN ENKULTURASI}

\section{SKRIPSI}

untuk memperoleh gelar Sarjana Pendidikan

\begin{tabular}{ll}
\multicolumn{1}{c}{ oleh } \\
Nama & $:$ Marissa Renimas Harlandea \\
NIM & $: 2501412024$ \\
Program Studi & $:$ Pendidikan Seni Drama, Tari, dan Musik \\
Jurusan & $:$ Pendidikan Seni Musik
\end{tabular}

FAKULTAS BAHASA DAN SENI UNIVERSITAS NEGERI SEMARANG 2016 


\section{PERSETUJUAN PEMBIMBING}

Skripsi ini telah disetujui oleh pembimbing untuk diajukan ke Sidang Panitia Ujian Skripsi.

Semarang, g Juni 2016

Pembimbing 1 ,

Pembimbing II,

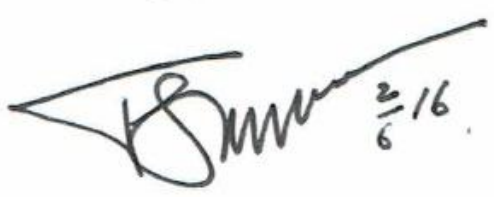

Prof. Dr. Totok Sumaryanto F, M.Pd.

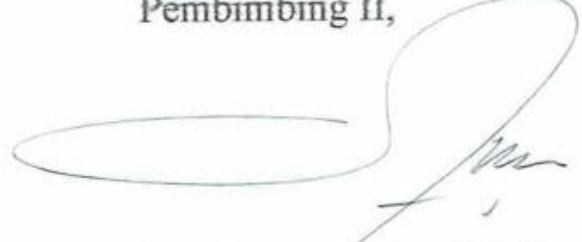

NIP 196410271991021001

Dr. Sunarto, S.Sn., M.Hum

NIP 196912151999031001 


\section{PENGESAHAN KELULUSAN}

Skripsi ini telah dipertahankan di hadapan sidang Panitia Ujian Skripsi Jurusan Pendidikan Seni Drama Tari dan Musik, Fakultas Bahasa dan Seni, Universitas Negeri Semarang

$$
\begin{array}{ll}
\text { pada hari } & \text { : Selasa } \\
\text { tanggal } & \text { : } 14 \text { Juni } 2016
\end{array}
$$

Panitia Ujian Skripsi

Drs Syahrul Syah Sinaga, M.Hum (196408041991021001) Ketúa

Abdul Rachman, S.Pd. M.Pd. (198001202006041002) Sekretaris

Drs. Bagus Susetyo, M.Hum. (196209101990111001) Penguji I

Dr. Sunarto, S.Sn., M.Hum (196912151999031001) Penguji II/Pembimbing II
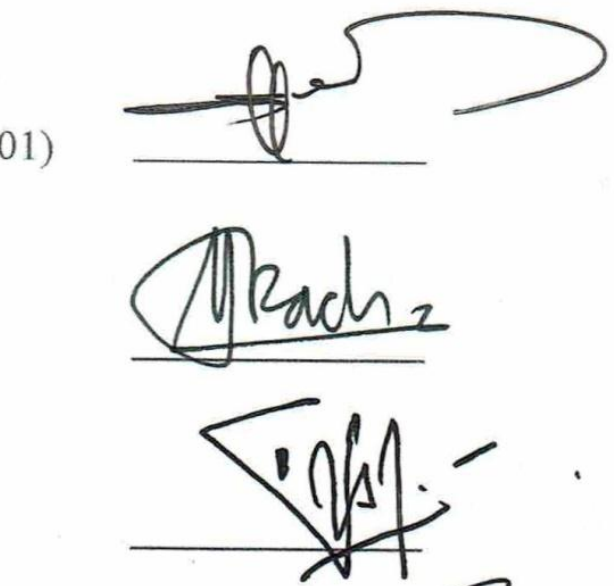

Prof. Dr. Totok Sumaryanto F, M.Pd. (196410271991021001) Penguji III/Pembimbing I

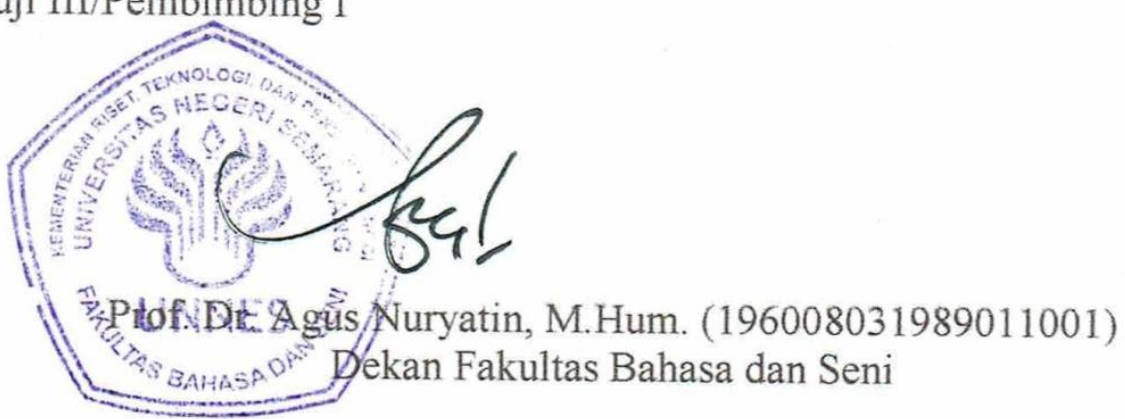




\section{PERNYATAAN}

Saya menyatakan bahwa yang tertulis dalam skripsi ini benar-benar hasil karya saya sendiri, bukan jiplakan dari karya orang lain, baik sebagian atau seluruhnya. Pendapat atau temuan orang lain yang terdapat dalam skripsi ini dikutip atau dirujuk berdasarkan kode etik ilmiah.

Semarang, 1 Juni 2106

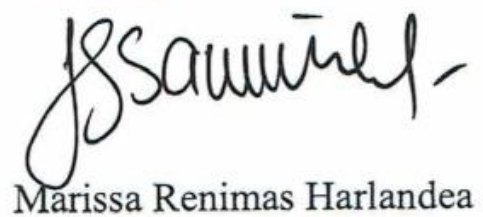




\title{
MOTTO DAN PERSEMBAHAN
}

\author{
Motto : \\ Bersikap kukuh seperti batu karang yang \\ tidak putus-putusnya dipukul ombak. Ia \\ tidak hanya berdiri kukuh, bahkan ia \\ menentramkan amarah ombak dan \\ gelombang itu. (Marcus Aurelius)
}

Persembahan :

Untuk Mama almh. Rismauli Hartati, Papa Mardji Roy, dan Mario adikku yang selalu memberi doa dan semangat.

Untuk seluruh keluarga dan sahabat yang senantiasa memberi dukungan dan senyuman bagi saya. 


\section{PRAKATA}

Puji syukur ke hadirat Tuhan Yang Maha Esa atas rahmat penyertaan-Nya sehingga penulis mampu menyelesaikan skripsi yang berjudul "Kesenian Gambang Kromong di Perkampungan Budaya Betawi Setu Babakan (Kajian Sejarah dan Enkulturasi)" sebagai salah satu syarat untuk memperoleh gelar Sarjana Pendidikan dari Jurusan Pendidikan Seni Musik Universitas Negeri Semarang.

Skripsi ini dapat diselesaikan juga karena adanya dukungan dari berbagai pihak yang membantu. Doa dan semangat dari kedua orang tua, keluarga, dan sahabat, bimbingan dari beberapa dosen yang memperlancar proses penyelesaian skripsi ini, serta dialog dan sumbang saran dari rekan-rekan di Perkampungan Budaya Betawi Setu Babakan dan Sanggar Seni Betawi Setu Babakan. Oleh karena itu, pada kesempatan ini penulis ingin menyampaikan rasa terimakasih yang kepada:

1. Prof. Dr. Fathur Rokhman, M.Hum., Rektor Universitas Negeri Semarang yang telah memberikan fasilitas selama melaksanakan perkuliahan.

2. Prof. Dr. Agus Nuryatin, M.Hum., Dekan Fakultas Bahasa dan Seni Universitas Negeri Semarang yang memberikan izin penelitian skripsi ini.

3. Dr. Udi Utomo, M.si., Ketua Jurusan Pendidikan Seni Drama Tari dan Musik Universitas Negeri Semarang yang telah memberi kemudahan dalam penyusunan skripsi ini. 
4. Prof. Dr. Totok Sumaryanto F, M.Pd., Dosen Pembimbing I yang telah meluangkan waktunya setiap kali ada kesempatan guna memberikan pengarahan dengan penuh kesabaran dan kesungguhan kepada penulis dalam penyusunan skripsi ini.

5. Dr. Sunarto, S.Sn., M.Hum., Dosen Pembimbing II yang telah memberikan berbagai kritik dan saran kepada penulis guna perbaikan penyusunan skripsi ini.

6. Segenap dosen Pendidikan Seni Drama Tari dan Musik Universitas Negeri Semarang yang telah memberikan ilmu.

7. Mama yang kini di Firdaus, Papa tersayang, Mario adikku, keluarga besar Ramidi dan Sitompul yang selalu menjadi motivasi dan semangat penulis.

8. Teman-teman Pendidikan Sendratasik Unnes, Rooskartiko Bagas Rahoetomo, Ellen, Abel, dan Icang yang telah memberikan senyuman dan semangat bagi penulis.

9. Rekan-rekan di Perkampungan Budaya Betawi dan Sanggar Seni Betawi Setu Babakan yang telah dengan ramah menyambut dan membantu penulis selama melakukan penelitian ini.

Akhir kata, penulis berharap semoga skripsi ini dapat menjadi karya yang bermanfaat bagi semua pihak. 


\section{SARI}

Harlandea, Marissa Renimas. 2016. Kesenian Gambang Kromong di Perkampungan Budaya Betawi Setu Babakan Jakarta Selatan (Kajian Sejarah dan Enkulturasi). Skripsi. Jurusan Pendidikan Seni Drama Tari dan Musik, Fakultas Bahasa dan Seni, Universitas Negeri Semarang. Pembimbing I: Prof. Dr. Totok Sumaryanto F, M.Pd. Pembimbing II: Dr. Sunarto, S.Sn., M.Hum.

Kata kunci: enkulturasi, gambang kromong, kebudayaan betawi

Kota Jakarta yang menjadi kota metropolitan membuat lingkungannya menerima banyak budaya luar yang mempengaruhi peradabannya. Kebudayaan Betawi, termasuk kesenian tradisi di dalamnya, kini tersingkir mundur oleh kebudayaan-kebudayaan lain yang masuk ke Jakarta. Para generasi muda yang adalah mata rantai pelestarian, justru banyak yang melupakan dan tidak mengenal kesenian tradisinya, sehingga membuat pewarisan antar generasi tersebut nyaris terputus. Di tengah kondisinya yang terpojokkan, masih ada pihak-pihak yang peduli terhadap kelestarian kesenian tradisi Betawi. Dukungan masyarakat dan pemerintah daerah DKI Jakarta, membuat kesenian tradisi Betawi kini mampu sedikit bernapas lega. Rumusan masalah dari skripsi ini adalah bagaimana sejarah Gambang Kromong di Perkampungan Budaya Betawi Setu Babakan dan bagimana proses enkulturasi kesenian tersebut di tengah masyarakatnya saat ini. Tujuan penelitian ini adalah mengetahui bagaimana sejarah dan proses pembudayaan kembali (enkuturasi) Gambang Kromong di Perkampungan Budaya Betawi Setu Babakan.

Menggunakan pendekatan penelitian deskriptif kualitatif, penelitian ini memperoleh data-datanya melalui teknik observasi, wawancara, dokumentasi, dan studi dokumen. Data yang diperoleh diperiksa keabsahannya melalui teknik triangulasi. Proses analisis data menggunakan model deskriptif kualitatif dimana data-data penelitian melalui tahap reduksi data, penyajian data, dan verifikasi data/penarikan kesimpulan.

Hasil dari penelitian ini menemukan fakta bahwa kesenian Gambang Kromong di Setu Babakan sudah ada sejak sebelum ditetapkannya Perkampungan Budaya Betawi di wilayah tersebut, namun kesenian Gambang Kromong itu melalui keadaan naik turun hingga akhirnya bertahan dengan kondisinya yang ada pada saat ini. Berawal dari program pemerintah DKI Jakarta yang mengadakan pembinaan kesenian di lingkungan Setu Babakan yang menjadi wilayah Perkampungan Budaya Betawi, hingga akhirnya warga masyarakat berinisiatif mendirikan sebuah wadah kesenian berupa Sanggar Seni Betawi Setu Babakan melalui swadaya masyarakat. Sanggar Seni Betawi Setu Babakan berdiri sejak tahun 2002 dan terus berkembang hingga saat ini, mengadakan pelatihan kesenian-kesenian Betawi diantaranya, Gambang Kromong, Tari, Teater, Silat Beksi. Proses enkulturasi kesenian tradisi Gambang Kromong di wilayah Perkampungan Budaya Betawi Setu Babakan terjadi melalui proses nonformal 
yaitu sanggar, dan secara informal melalui keluarga dan lingkungan masyarakat. Proses enkulturasi melalui sanggar terjadi secara teratur dan terprogram dalam latihan rutin di Sanggar Seni Betawi Setu Babakan yaitu pada hari Jumat malam dan hari Minggu pagi. Peserta didik sanggar menerima pelajaran dari pendidik atau pelatihnya dengan melalui beberapa tahapan yaitu, proses perkenalan, proses melihat, meniru, serta proses pembinaan. Proses enkulturasi dalam keluarga dan lingkungan masyarakat terjadi melalui proses pelaziman terhadap anak (peserta didik). Proses enkulturasi dalam secara informal di dalam keluarga, terjadi karena para orang tua yang merupakan panjak (pemusik) Gambang Kromong, biasa mengajak anaknya saat latihan-latihan baik itu di sanggar maupun dirumah. Anak dari panjak yang ikut menyaksikan latihan menjadi terbiasa mendengar, melihat, dan bahkan mencoba bermain-main dengan alat Gambang Kromong, membuatnya menjadi suka musik Gambang Kromong dengan sendirinya, dan kemudian mempelajari musik ini dari orang tuanya.

Penulis memberikan saran bagi masyarakat Betawi, untuk terus mencintai dan melestarikan kesenian Gambang Kromong dan kesenian Betawi lainnya. Saat ini memang kesenian Betawi sedang kembali bermunculan, oleh karena itu, dibutuhkan dukungan dari masyarakatnya untuk terus mempertahankan keadaan baik ini. Bagi pemerintah DKI Jakarta, agar tanpa rasa jemu, dapat terus mendukung masyarakatnya dalam hal yang berkaitan proses pembudayaan kesenian tradisi. 


\section{DAFTAR ISI}

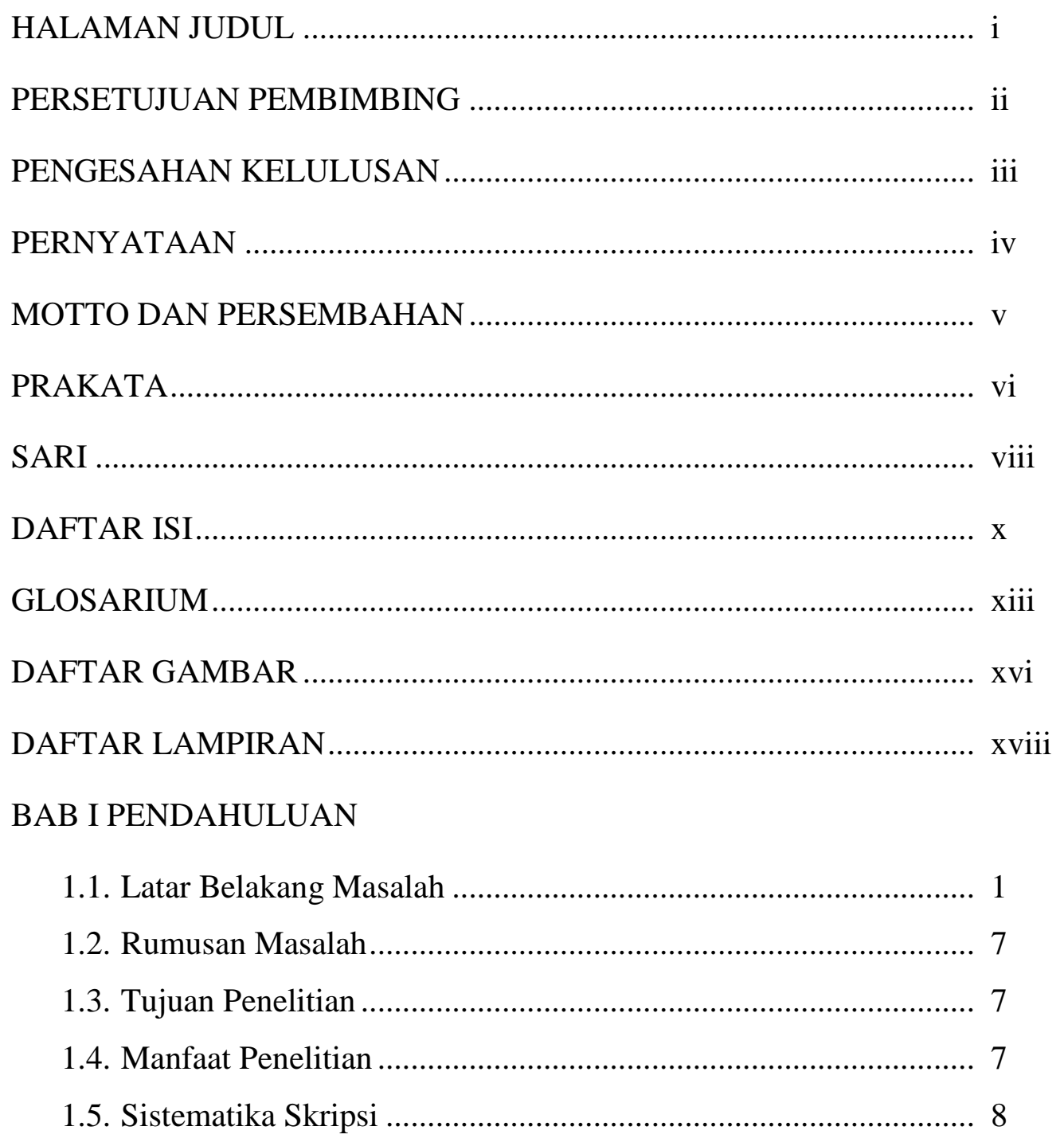

\section{BAB II TINJAUAN PUSTAKA DAN LANDASAN TEORETIS}

2.1. Tinjauan Pustaka................................................................. 9

2.2. Landasan Teoretis

2.2.1 Kebudayaan.............................................................. 12

2.2.2 Musik Tradisi ................................................................ 13

2.2.3 Gambang Kromong.................................................. 15

2.2.4 Kajian Sejarah ........................................................ 19 
2.2.5 Konsep Enkulturasi ...................................................... 20

2.3. Kerangka Berpikir................................................................. 23

\section{BAB III METODE PENELITIAN}

3.1. Pendekatan Penelitian ................................................................. 26

3.2. Sumber Data .......................................................................... 26

3.3. Teknik Pengumpulan Data........................................................ 27

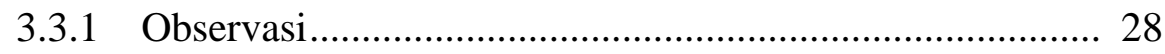

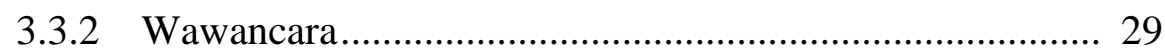

3.3.3 Studi Dokumen dan Dokumentasi .................................. 30

3.4. Teknik Pemeriksaan Keabsahan Data......................................... 31

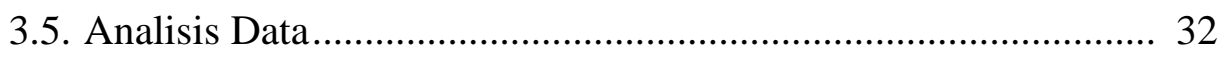

3.5.1 Reduksi Data ............................................................ 33

3.5.2 Penyajian Data .......................................................... 34

3.5.3 Verifikasi Data atau Penarikan Kesimpulan ..................... 34

\section{BAB IV HASIL DAN PEMBAHASAN}

4.1. Gambaran Umum Lokasi Penelitian

4.1.1 Perkampungan Budaya Betawi ..................................... 36

4.1.2 Sanggar Seni Betawi Setu Babakan Pimpinan Sahroni ..... 51

4.2. Sejarah Musik Gambang Kromong di Perkampungan Budaya

Betawi Setu Babakan .................................................................... 55

4.3. Enkulturasi Musik Gambang Kromong di Perkampungan Budaya Betawi Setu Babakan

4.3.1 Enkulturasi Musik Gambang Kromong di Perkampungan

Budaya Betawi Setu Babakan Melalui Jalur Informal

(Keluarga dan Lingkungan Masyarakat).

4.3.2 Enkulturasi Musik Gambang Kromong di Perkampungan

Budaya Betawi Setu Babakan Melalui Jalur Nonformal (Sanggar)

4.3.3 Perubahan-perubahan Musik Gambang Kromong di 
Perkampungan Budaya Betawi dalam Proses

Enkulturasinya …............................................................. 83

\section{BAB V PENUTUP}

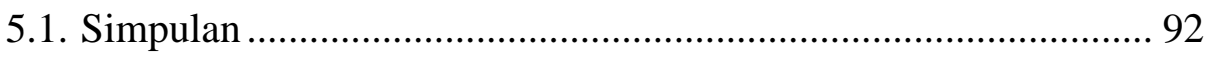

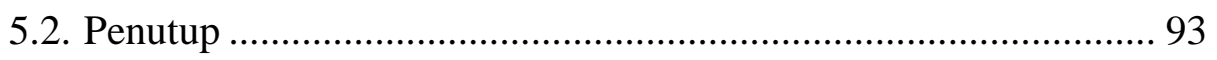

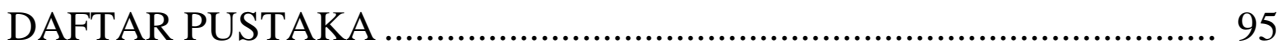

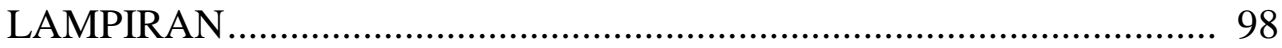




\title{
GLOSARIUM
}

\author{
Abstraksi \\ : metode untuk mendapatkan pengertian melalui \\ penyaringan terhadap gejala atau peristiwa. \\ Adaptasi \\ : penyesuaian terhadap lingkungan. \\ Agen enkulturasi : orang atau lembaga yg mendorong terciptanyaproses \\ pembudayaan/enkulturasi. \\ Akulturasi \\ :percampuran dua kebudayaan atau lebih yang saling \\ bertemu dan saling mempengaruhi. \\ Animo \\ : semangat; hasrat dan keinginan yang kuat untuk berbuat, \\ melakukan, atau mengikuti sesuatu. \\ Budayawan : orang yang berkecimpung dalam kebudayaan; ahli \\ kebudayaan \\ Cagar budaya $\quad$ : daerah yang kelestarian hidup masyarakat dan peri \\ kehidupannya dilindungi oleh undang-undang dari bahaya \\ kepunahan. \\ Cendekiawan $\quad$ : orang yang memiliki sikap hidup yang terus-menerus \\ meningkatkan kemampuan berpikirnya untuk dapat \\ mengetahui atau memahami sesuatu. \\ Diatonis \\ :tangga nada yang terdiri dari tujuh buah nada. \\ Empiris

\section{Enkulturasi Etimologi} \\ Etnis \\ : berdasarkan pengalaman (terutama yang diperoleh dari \\ penemuan, percobaan, pengamatan yang telah dilakukan). \\ : pembudayaan. \\ : cabang ilmu bahasa yang menyelidiki asal-usul kata serta \\ perubahan dalam bentuk dan makna. \\ : bertalian dengan kelompok sosial dalam sistem sosial atau \\ kebudayaan yang mempunyai arti atau kedudukan tertentu \\ Etnografi \\ Gaung \\ Globalisasi \\ Humaniora \\ Improvisasi \\ Inovasi \\ : deskripsi tentang kebudayaan suku-suku bangsa yang \\ hidup. \\ : Kumandang, Gema. \\ :proses integrasi internasional yang terjadi karena \\ pertukaran pandangan dunia, produk, pemikiran, dan \\ aspek-aspek kebudayaan lainnya. \\ : ilmu pengetahuan yang meliputi filsafat, hukum, sejarah, \\ bahasa, sastra, seni, dsb. \\ : penciptaan atau pertunjukan musik tanpa persiapan lebih \\ dahulu. \\ : pemasukan atau pengenalan hal-hal yang baru atau \\ penemuan baru yang berbeda dari yang sudah ada atau \\ yang sudah dikenal sebelumnya (gagasan, metode, atau \\ alat).
}


Integrasi

\section{Internalisasi \\ Kolaborasi \\ Kolektif \\ Komunal \\ Kongahyan}

Laras

Lokakarya

Masif

Metode

Metropolitan

Modernisasi

Ngibing

Ningnong

Normatif

Notasi musik

Orkes

Otonom

Panjak

Pentatonis

Pranata

Regulasi
: penyesuaian antara unsur kebudayaan yang saling berbeda sehingga mencapai suatu keserasian fungsi dalam kehidupan masyarakat.

: penghayatan.

: kerja sama.

: secara bersama; secara gabungan.

: berkaitan dengan milik rakyat atau umum.

:instrumen gesek berdawai dua berukuran kecil, dilaras dalam nada liuh (g) dan che (d).

:tangga nada.

: pertemuan antara para ahli (pakar) untuk membahas masalah praktis atau yang bersangkutan dengan pelaksanaan dalam bidang keahliannya.

: sesuatu yang terjadi secara besar-besaran atau skalanya luas.

: cara kerja yang bersistem untuk memudahkan pelaksanaan suatu kegiatan guna mencapai tujuan yang dikehendaki.

: kota yang menjadi pusat kegiatan tertentu, baik pemerintahan maupun industri dan perdagangan. : proses pergeseran sikap dan mentalitas sebagai warga masyarakat untuk dapat hidup sesuai dengan tuntutan masa kini.

:tarian yang dilakukan berpasangan dengan Wayang Cokek.

: instumen musik yang terdiri atas dua buah piringan kecil (canang) perunggu atau kuningan pada sebuah bingkai yang bertangkai. Dipukul dengan penabuh logam secara berganti-ganti, misalnya kiri-kanan-kiri, sesuai dengan irama.

: berpegang teguh pada norma; menurut norma atau kaidah yang berlaku.

:sistem penulisan karya musik.

: kelompok pemain musik yang bermain bersama pada seperangkat alat musiknya.

: berdiri sendiri.

:pemain musik/pemusik.

:sebuah tangga nada yang terdiri hanya dari lima nada pokok (Penta yang berarti lima; dan Tone yang berarti nada)

: sistem tingkah laku sosial yang bersifat resmi serta adatistiadat dan norma yang mengatur tingkah laku itu, dan seluruh perlengkapannya guna memenuhi berbagai kompleks kebutuhan manusia dalam masyarakat; institusi. : pengaturan. 
Reka cipta

Repertoar

Representatif

Revitalisasi

Salendro

Sanggar

Setu

Sosialisasi

Sporadis

Strategi

Sukong

Swadaya

Tehyan

Vakum

Vokalis

Wayang Cokek
: penciptaan (perancangan) sesuatu yang sebelumnya tidak ada.

: daftar lagu yang akan disajikan oleh pemain musik, penyanyi, dsb.

: dapat (cakap, tepat) mewakili.

: proses, cara, perbuatan menghidupkan atau menggiatkan kembali.

:tangga nada pentatonis yang terdiri atas unsur g-a-c-d-e. : tempat untuk kegiatan seni (musik, tari, lukis, dsb).

: danau.

: upaya memasyarakatkan sesuatu sehingga menjadi dikenal, dipahami, dihayati oleh masyarakat;

pemasyarakatan.

: tidak tentu.

: rencana yang cermat mengenai kegiatan untuk mencapai sasaran khusus.

:instrumen gesek berdawai dua, semacam rebab berukuran besar dan berasal dari Tiongkok, dilaras dalam nada

su(a) dan kong (e). Tabung di bagian bawah sering terbuat dari cangkang buah berenuk yang keras.

: kekuatan (tenaga) sendiri.

:Instrumen gesek berdawai dua berukuran sedang yang dilaras dalam nada siang (e) dan liuh (g).

: kekosongan; tidak berfungsi.

: penyanyi.

:penyanyi dalam Gambang Kromong, namun sejak abad ke-19 dianggap sebagai penari, bukan lagi penyanyi. 


\section{DAFTAR GAMBAR}

Gambar

Halaman

2.2.3.1. Instrumen Kromong ...................................................................... 17

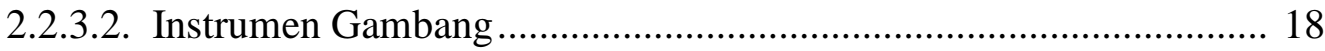

4.1.1.1. Peta Lokasi Perkampungan Budaya Betawi .................................. 37

4.1.1.2. Penulis dengan Bang Indra Sutisna.............................................. 39

4.1.1.3. Pintu Gerbang Bang Pitung .......................................................... 41

4.1.1.4. Panggung Teater Terbuka ................................................................. 42

4.1.1.5. Wisma / Guess House ...................................................................... 42

4.1.1.6. Contoh Rumah Adat.......................................................................... 43

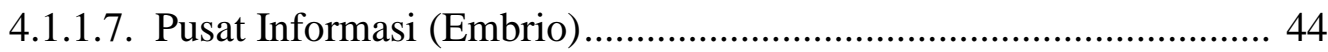

4.1.1.8. Zona A Perkampungan Budaya Betawi .......................................... 45

4.1.1.9. Kegiatan Rekreasi Pengunjung Perkampungan Budaya Betawi Berupa Memancing dan Naik Perahu ........................................... 49

4.1.1.10. Toko Souvenir Khas Betawi ...................................................... 49

4.1.1.11. Pedagang Kerak Telor Khas Betawi ............................................. 50

4.1.1.12. Pedagang Dodol Khas Betawi ..................................................... 50

4.1.2.1. Penulis dengan Bang Sahroni ...................................................... 52

4.1.2.2. Panggung Teater Terbuka Sebagai Lokasi Latihan Berbagai Kesenian Betawi 52

4.1.2.3. Panggung Teater Terbuka Sebagai Lokasi Latihan Berbagai Kesenian Betawi 53

4.2.5.1. Rendy Bersama Tim Kolaborasi Kesenian Betawi dan Jawa Barat Di Gedung Kedubes RI di Praha 64

4.3.1.1. Bang Erik yang Kerap Membawa Banu Anaknya Saat Latihan 
Musik Gambang Kromong .67

4.3.1.2. Penulis dengan Bang Erik .68

4.3.2.1. Proses Pemberian Contoh Oleh Bang Andi Pada Peserta Sanggar Pemain Gambang. 74

4.3.2.2. Praktik Bermain Lagu Gambang Kromong 74

4.3.2.3. Proses Latihan/Pembinaan Generasi ke-3 Gambang Kromong Sanggar Seni Betawi Setu Babakan 75

4.3.2.4. Pentas Generasi ke-4 Gambang Kromong Sanggar Seni Betawi Setu Babakan di Gedung Balai Latihan Kesenian Tanah Abang...... 77

4.3.2.5 Pentas Generasi ke-4 Gambang Kromong Sanggar Seni Betawi Setu Babakan dalam Acara Pergelaran Evaluasi Hasil Pelatihan Kesenian 77

4.3.2.6. Pentas Generasi ke-3 Gambang Kromong Sanggar Seni Betawi Setu Babakan Saat Tampil di Hotel Mercure Ancol 78

4.3.2.7. Orang Tua Peserta Didik Sanggar yang Membantu Mengkondisikan Saat Latihan Akan Dimulai 78

4.3.2.8. Contoh Repertoar yang Dibuat Bang Andi Untuk Mendukung Proses Pembelajaran Gambang Kromong di Sanggar Seni Betawi Setu Babakan 80

4.3.3.1. Instrumen Rebab .87

4.3.3.2. Instrumen Rebana, Ketimpring, Bedug .88

4.3.3.3. Penulis dengan Bang Andi 89 


\section{DAFTAR LAMPIRAN}

Halaman

$\begin{array}{lll}\text { Lampiran } 1 & \text { Pedoman Observasi } & 99\end{array}$

$\begin{array}{lll}\text { Lampiran } 2 & \text { Pedoman Wawancara }\end{array}$

Lampiran 3 Pedoman Studi Dokumen dan Dokumentasi 102

Lampiran $4 \quad$ Transkrip Wawancara 103

Lampiran 5 Catatan Lapangan 113

Lampiran 6 Struktur Kepengurusan Sanggar Seni Betawi Setu Babakan 115

Lampiran 7 Struktur Lembaga Pengelola Perkampungan Budaya Betawi 116

$\begin{array}{lll}\text { Lampiran } 8 & \text { Profil Narasumber } & 117\end{array}$

Lampiran 9 Surat Keputusan Dosen Pembimbing Skripsi 119

Lampiran 10 Surat Permohonan Izin Penelitian 120

$\begin{array}{lll}\text { Lampiran } 11 & \text { Surat Izin Penelitian } & 122\end{array}$ 


\section{BAB I \\ PENDAHULUAN}

\subsection{Latar Belakang Masalah}

Keragaman budaya merupakan sebuah konsekuensi yang akan dihadapi oleh suatu daerah yang keadaannya dihuni oleh banyak suku, yang kemudian saling mempengaruhi, hingga ada keadaan dimana keragaman itu sendiri menjadi karakter daerah tersebut.Tanpa kebudayaan, suatu masyarakat tidak memiliki identitas yang jelas. Indonesia adalah negara kepulauan yang memiliki banyak suku bangsa. Suku bangsa tersebut kemudian memiliki kebudayaan berbeda-beda sehingga membuat Indonesia kaya akan budaya tradisi. Kebudayaan yang kuat sebagai pemberi jati diri bangsa, artinya; ia tidak boleh dengan mudah termakan atau terpinggirkan di hadapan kebudayaan-kebudayaan lain di jagat ini (Tindaon, 2012). Mengacu pada semboyan bhineka tunggal ika, maka ada dua aspek kebudayaan Indonesia yang sekaligus perlu dibangun atau dilestarikan yaitu, disatu sisi kebudayaan nasional dan disisi lain kebudayaan-kebudayaan suku-suku bangsa yang ada di Indonesia (Tindaon, 2012).

Menurut Koentjaraningrat (1990:181) kebudayaan dengan kata dasar budaya berasal dari bahasa sangsakerta "buddhayah", yaitu bentuk jamak dari buddhi yang berarti "budi" atau "akal". Koentjaraningrat mendefinisikan budaya sebagai "daya budi" yang berupa cipta, karsa, dan rasa. Sedangkan kebudayaan adalah hasil dari cipta, karsa, dan rasa itu. Terdapat unsur-usur pokok yang terkandung dalam kebudayaan, dimana salah satuunsur tersebut adalah kesenian. 
Masing-masing suku bangsa Indonesia memiliki kesenian tradisi. Tradisi dapat dipahami sebagai apapun yang dilakukan oleh manusia secara turun temurun dari setiap aspek kehidupannya yang merupakan upaya untuk meringankan hidup manusia. Tradisi bisa dirubah, diangkat, ditolak, dan dipadukan dengan aneka ragam perbuatan manusia.Kesenian tradisi dapat diartikan sebagai kesenian masa lalu yang diciptakan oleh nenek moyang dan sampai sekarang masih dijalankan atau dimainkan oleh masyarakat kontemporer.

Setiap kebudayaan yang hidup dalam suatu masyarakat yang berwujud sebagai komunitas desa, atau kota, atau sebagai kelompok adat yang lain, bisa menampilkan suatu corak yang khas. Hal tersebut dapat dilihat oleh orang luar yang bukan warga masyarakat bersangkutan. Corak khas dari suatu kebudayaan bisa tampil karena kebudayaan itu menghasilkan suatu unsur kecil, berupa suatu unsur kebudayaan fisik dengan bentuk yang khusus, atau karena diantara pranatapranatanya terdapat suatu pola sosial yang khusus, atau dapat juga karena warganya menganut suatu tema budaya yang khusus. Berdasarkan corak khusus tersebut, suatu kebudayaan dapat dibedakan dengan kebudayaan lain. Istilah etnografi untuk suatu kebudayaan dengan corak khas adalah "suku bangsa" atau dalam bahasa Inggris adalah “ethnic group” (Fathoni, 2006:46-47).

Suku bangsa Betawi adalah suatu suku bangsa Indonesia yang berada di wilayah pulau Jawa. Penduduk asli Betawi adalah penduduk yang mendiami daerah Jakarta dan sekitarnya, mereka tinggal sejak zaman dahulu (Dinas Kebudayaan dan Permuseuman DKI Jakarta, 2002:10). Jakarta sejak abad terdahulu sudah menjadi kota raya dan sangat terkenal di dunia. Kondisi 
masyarakat Jakarta yang harmonis, alamnya tedung, jalan dan perumahan sangat teratur, dan sangat menguntungkan untuk berdagang, sangat menarik perhatian orang dari luar Jakarta untuk datang dan menetap sebagai penduduk. Kedatangan para penduduk dari dalam maupun luar negeri mempengaruhi pertumbuhan kebudayaan Jakarta, terutama di daerah kota (Dinas Kebudayaan dan Permuseuman DKI Jakarta, 2002:26). Secara administratif, persebaran wilayah tempat orang Betawi berdiam ada yang menjadi penduduk DKI Jakarta, penduduk Kabupaten Tangerang,penduduk Kotamadya Tangerang, penduduk Kabupaten Bekasi, penduduk Kotamadya Bekasi, penduduk Kotamadya Depok, dan penduduk Kabupaten Bogor.

Suku bangsa betawi memiliki kesenian tradisi yang beragam dari berbagai disiplin seni seperti seni rupa tradisi, seni tari tradisi, dan seni musik tradisi.Seni rupa tradisi betawi diantaranya ada seni arsitektur betawi, ragam hias, dan pakaian khas betawi. Seni tari Betawi diantaranya terdapat tari topeng betawi, tari cokek, tari blenggo, tari japin atau zapin, tari samrah, tari uncul, tari pencak silat, dan tari kreasi baru yang masih banyak lagi ragamnya. Selain seni rupa dan tari tradisi betawi, juga terdapat seni musik tradisi betawi seperti gambang kromong, tanjidor, keroncong tugu, gamelan ajeng, gamelan topeng, samrah, dan beberapa jenis rebana. Seni tradisiBetawi adalah hasil akulturasi (percampuran) budaya, keberadaannya dipengaruhi olehbudaya-budaya lain seperti Eropa, Tionghoa, Arab, Melayu, Sunda dan lain-lainnya (Yahya dan Nurzain, 2009:5).

Gambang Kromongadalah seni musik tradisiyang lahir dari kaum pernakan di Betawi. Gambang Kromong sendiri diambil dari nama alat 
musikyang dipakai dalam orkes tersebut, yaitu gambang dan kromong. Musik ini pada awalnya dibawa oleh kaum Tionghoa peranakan, dan awalnya hanya digemari oleh kaum Cina saja, namun lama-kelamaan orkes ini diadopsi oleh masyarakat Betawi. Gambang Kromong merupakan paduan yang serasi antara unsur pribumi dan Cina. Unsur Cina tampak pada instrumen seperti tehyan,kongahyan, dan sukong, sementara unsur pribumi berupa kehadiran instrumen seperti gendang, kempul, gong, gong enam, kecrek, dan ningnong (Yahya dan Nurzain, 2009:6-7).

Pemerintah DKI Jakarta pada saat ini tengah berupaya melestarikan kebudayaan yang ada di wilayah Betawi yang lambat laun mulai pudar di tengah kemajuan zaman yang serba modern.Kesenian Gambang Kromong termasuk kesenian yang masih eksis di wilayah Jakarta dan sekitarnya, namun juga boleh dikatakan dalam keadaan kritis. Hal ini disebabkan oleh modernisasi yang terus berkembang pesat terutama di wilayah Ibukota Jakarta yang membuat kesenian tradisi Betawi semakin tersisihkan dari masyarakat. Minat para pemuda generasi masa kini untuk terus mempertahankan keberadaan budaya tradisi telah memudar. Mereka seakan cuek terhadap masalah yang dihadapi budaya tradisi, terpikat oleh perkembangan zaman. Banyaknya aliran-aliran musik yang baru dan lebih modern yang telah menghipnotis semua orang, sehingga banyak orang yang telah melupakan musik tradisional dan beralih pada musik modern, sehingga remajaremaja sekarang kurang mengenal kesenian dari daerahnya sendiri. Anggapananggapan seperti ini jelas akan membuat kesenian-kesenian tradisional Betawi mengalami kepunahan. 
Dalam skripsi Rizkiyah Hasanah (2012) yang meneliti tentang strategi adaptasi kelompok musik Gambang Kromong dalam menghadapi perubahan sosial menyatakan bahwa kelompok musik Gambang Kromong yang kini masih hadir di tengah masyarakat bukan dengan mudah tetap berdiri tegak, para kelompok musik Gambang Kromong telah melakukan usaha-usaha diantaranya dengan melakukan perubahan dalam penyajian musiknya. Perubahan-perubahan yang dilakukan tersebut tentunya dilakukan dengan tujuan sebagai upaya pemertahanan kebudayaan tradisi agar tetap bisa eksis diterima masyarakat.

Hasil penelitian dari Siti Uswatun Chasanah (UIN 2014) dalam skripsinya menyatakan bahwa keberadaan Gambang Kromong yang masih bertahan sampai saat ini juga merupakan hasil kerja pemerintah daerah dalam menjaga dan melestarikan kesenian tersebut. Telah banyak cara telah ditempuh oleh pemerintah daerah DKI Jakarta, salah satu jalan yang sudah dilakukan pemerintah Jakarta untuk melindungi kesenian tradisi Betawi adalah, dengan membuat perkampungan budaya Betawi yang lokasinya dipilih di daerah Setu Babakan Srengseh Sawah Jakarta Selatan.

Perkampungan Budaya Betawi Setu Babakan kini menjadi lokasi yang dapat kita pilih ketika mencari kebudayaan Betawi di tengah modernisasi Ibukota, di sana kita dapat menjumpai penduduk asli Betawi, arsitektur rumah adat Betawi, makanan khas Betawi, pernak-pernik atau souvenir khas Betawi, dan berbagai kesenian tradisi Betawi. Jalan pemerintah untuk merevitalisasi budaya tradisi Betawi melalui Setu Babakan ini dirasa sejalan dengan pendapat Rosmegawaty Tindaon (2012) mengenai kesenian tradisi dan revitalisasi, yang menyatakan: 
"Kebudayaan akan menjadi sesuatu yang bermakna bagi masyarakatjika dikelola dan dipandu secara sadar, agar pada akhirnya kebudayaan itu dapat berfungsi sebagai suatu sarana identitas yang bersifat mengangkat martabat manusia. Banyak pihak yang sebenarnya berkepentingan dan seharusnya bertanggung jawab mengenai perkembangan kebudayaan, pihak-pihak utama dalam masyarakat yang bertanggung jawab dalam proses kebudayaan antaralain orang tua atau pendidik, dan pihak-pihak lain yang memang berkompeten dalam hal itu."

Penulis tertarik meneliti lebih jauh mengenai sejarah musik Gambang Kromong yang ada di Perkampungan Budaya Betawi Setu Babakan Jakarta Selatan, serta mengetahui bagaimana enkulturasi musik Gambang Kromong disana. Musik Gambang Kromong diangkat sebagai subjek penelitian ini dengan alasan Gambang Kromong adalah salah satu musik karawitan Betawi yang sampai saat ini masih bertahan dan digunakan dalam setiap acara kebetawian. Gambang Kromong juga dipilih karena perkembangannya yang dirasa unik menurut penulis. Hal lain yang menjadi alasan penulis untuk mengkaji sejarah dan enkulturasi musik Gambang Kromong di Perkampungan Budaya BetawiSetu Babakan karena, dari sekian banyak penelitian-penelitian terdahulu seputar Gambang Kromong di Perkampungan Budaya Betawi,belum pernah ada yang mengangkat dari sudut kajian sejarah dan enkulturasi. 


\subsection{Rumusan Masalah}

Berdasarkan latar belakang tersebut maka,penelitimerumuskan masalah penelitian ini sebagai berikut:

1. Bagaimana sejarah musik Gambang Kromong di Perkampungan Budaya Betawi Setu Babakan Jakarta Selatan?

2. Bagaimana proses enkulturasi musik Gambang Kromong di Perkampungan Budaya Betawi Setu Babakan Jakarta Selatan?

\subsection{Tujuan Penelitian}

Berdasarkan rumusan masalah yang ada maka, tujuan dari penelitian ini adalah untuk:

1. Mengetahui dan mendeskripsikan sejarah musik Gambang Kromong di Perkampungan Budaya Betawi Setu Babakan Jakarta Selatan.

2. Mengetahui dan mendeskripsikanproses enkulturasi musik Gambang Kromong di Perkampungan Budaya Betawi Setu Babakan Jakarta Selatan.

\subsection{Manfaat Penelitian}

Manfaat hasil penelitian ini terbagi menjadi manfaat teoritis dan manfaat praktis:

\subsubsection{Manfaat teoritis:}

1. Penelitian ini dapat dijadikan masukan dalam penelitian-penelitian selanjutnya mengenai konsep sejarah dan enkulturasi musik tradisiBetawi Gambang Kromong.

2. Memberikan kontribusi pada aspek kebudayaan musik tradisi Betawi Gambang Kromong. 


\subsubsection{Manfaat praktis:}

1. Bagi peneliti sendiri untuk memahami sekaligus memberi informasi berupa tulisan mengenai kesenian tradisi Gambang Kromong.

2. Dapat memberi masukan positif bagi masyarakat Betawi dan Pemerintah DaerahDKI Jakarta untuk terus mengembangkan proses enkulturasi kesenian tradisi masyarakatnyayang kian memudar.

\subsection{Sistematika Skripsi}

Untuk mempermudah pemahaman dan penulisan dalam penyusunan skripsi ini, maka dalam penyajiannya penulis membagi secara sistematis kedalam lima bab yang secara garis besarnya dapat dijelaskan sebagai berikut:

Bab I:merupakan pendahuluan yang berisi uraian mengenai latar belakang masalah penelitian, rumusan masalah, tujuan penelitian, dan manfaat penelitian,

Bab II: tinjauan pustaka, landasan teoritis, dan kerangka berpikir.

Bab III: menguraikan metode penelitian yang digunakan dalam skripsi ini, di dalamnya terdapat teknik pendekatan penelitian, sumber data, teknik pengumpulan data, teknik pemeriksaan keabsahan data, dan teknik analisis data.

Bab IV: hasil penelitian yang diperoleh dan pembahasannya.

Bab V: berisi penutup yang di dalamnya terdapat simpulan penelitian dan saran dari penulis.

Di bagian akhir penelitian ini juga terdapat daftar pustaka, dan lampiranlampiran terkait penelitian ini. 


\section{BAB II}

\section{TINJAUAN PUSTAKA DAN LANDASAN TEORETIS}

\subsection{Tinjauan Pustaka}

Banyak penelitian yang mengambil topik kesenian tradisi Betawi, baik itu dari kajian sejarah, sosial, humaniora, revitalisasi, dan lain-lain. Beberapa diantaranya telah penulis dapatkan sebagai tinjauan pustaka penulisan skripsi ini. Pertama, skripsi dari Rizkiyah Hasanah, mahasiswa Fakultas Ilmu Sosial dan Ilmu Politik, UIN Syarif Hidayatullah Jakarta tahun 2012, yang mengangkat topik kesenian tradisi Betawi Gambang Kromong dengan judul, "Strategi Adaptasi Kelompok Musik Gambang Kromong dalam Menghadapi Perubahan Sosial (Studi Kasus Kelompok Musik Gambang Kromong Mustika Forkabi”. Hasil penelitian tersebut menyatakan kelompok musik Gambang Kromong dalam menghadapi perubahan sosial menyatakan bahwa kelompok musik Gambang Kromong masih dapat bertahan hingga saat ini, dengan konsekuensi tawaran bermain tidak seramai di tahun 1970-an. Hal ini dikarenakan banyaknya keberadaan kesenian modern, sehingga kesenian tradisional mulai terlupakan dan juga mengalami perubahan. Maka, kelompok musik Gambang Kromong melakukan perubahan yang dapat dilihat dari adanya penambahan alat-alat musik, adanya pengkombinasian lagu-lagu yang dinyanyikan.

Siti Uswatuh Chasanah, Fakultas Adab dam Humaniora UIN Jakarta Syarif Hidayatullah, program studi Sejarah dan Kebudayaan Islam tahun 2014, dalam skripsinya yang berjudul "Penerimaaan Masyarakat Betawi Muslim 
Terhadap Kesenian Musik Gambang Kromong dan Tari Ronggeng Blantek di Perkampungan Budaya Betawi Setu Babakan", menyimpulkan hasil penelitian bahwa proses penerimaaan kesenian musik Gambang Kromong dan tari Ronggeng Blantek pada masyarakat Betawi Muslim di perkampungan budaya Betawi Setu Babakan didasari pada konsistensi yang kuat serta pengejawantahan sikap dan perilaku masyarakat muslim Betawi terhadap Islam. Serta adanya peran pemerintah daerah dalam menjaga dan melestarikan kesenian tersebut. Kini kesenian musik Gambang Kromong dan tari Ronggeng Blantek telah melekat sebagai kesenian masyarakat Betawi.

Demikian juga dengan Ali Abdul Rodzik Fakultas Dakwah dan Komunikasi UIN Jakarta Syarif Hidayatullah, Jurusan Komunikasi dan Penyiaran Islam Tahun 2008, yang juga mengambil topik penelitian Kesenian Tradisional Betawi dengan judul "Akulturasi Budaya Betawi DenganTionghoa (Studi komunikasi antarbudaya pada kesenian GambangKromong di Perkampungan Budaya Betawi, Kelurahan Srengseng Sawah).” Ali Abdul Rodzik menyimpulkan beberapa hal dari penelitiannya yaitu, komunikasi personal dalam akulturasi yang terjadi pada kesenian Gambang Kromong yaitu pada saat orang Tionghoa mengadu nasib ke Batavia untuk berdagang. Dan dikarenakan meraka tinggal dalam jangka waktu yang lama mau tidak mau mereka mempelajari pola-pola relasi, aturan-aturan, dan sistem komunikasi orang-orang Betawi. Proses komunikasi antara orang Tionghoa dan orang Betawi ini menghasilkan suatu kesenian yang sekarang dikenal dengan kesenian Gambang Kromong. Lingkungan komunikasi merupakan faktor pendukung dalam proses akulturasi. 
Jurnal oleh Rosmegawaty Tindaon (2012) dengan judul “Kesenian dan Revitalisasi" menjadi referensi pendukung dalam penelitian ini. Hasil penelitian tersebut menghasilkan pernyataan bahwa, kebudayaan akan menjadi sesuatu yang bermakna bagi masyarakat jika dikelola dan dipandu secara sadar, agar pada akhirnya kebudayaan itu dapat berfungsi sebagai suatu sarana identitas yang bersifat mengangkat martabat manusia. Pemerintah dan masyarakat turut bertanggung jawab akan pemertahanan kebudayaan.

Triyanto (2015) mahasiswa pascasarjana Universitas Negeri Semarang, program studi pendidikan seni, dalam disertasinya yang berjudul "Enkulturasi Perkeramikan Pada Komunitas Perajin Desa Mayong Lor Jepara: Strategi Adaptasi dan Pemberlanjutan Potensi Kreatif Kebudayaan Lokal”, memberi hasil penelitian bahwa proses enkulturasi yang berlangsung dalam keluarga ternyata mampu menjadi mekanisme pemertahanan potensi kreatif kebudayaan lokal secara lintas generasi.

Penelitian-penelitian yang dipaparkan di atas merupakan penelitian yang serupa dengan penelitian ini, sama-sama meneliti tentang kesenian tradisi yang kini mulai terhimpit perkembangan zaman. Perbedaan penelitian dalam skripsi ini adalah dari bidang kajian yang mengkaji sejarah dan proses enkulturasi Gambang Kromong di Perkampungan Budaya Betawi Setu Babakan. Sejauh penulis ketahui, belum ada penelitian sebelumnya yang membahas bidang kajian sama dengan penulis, oleh sebab itu penelitian ini menjadi cukup menarik untuk diteliti. 


\subsection{Landasan Teoretis}

\subsubsection{Kebudayaan}

Secara etimologi, Koentjaraningrat (1990:181) menyatakan kebudayaan berasal dari bahasa Sansekerta "buddhayah" yang merupakan bentuk jamak dari "buddhi" yang berarti "budi" atau "akal". Dengan demikian, kebudayaan dapat diartikan hal-hal bersangkutan dengan budi dan akal manusia.Dalam bahasa Inggris, kata yang sepadan dengan kebudayaan disebut culture, yang berasal dari kata Colere (Latin), yaitu mengolah atau mengerjakan.Bisa diartikan juga sebagai mengolah tanah atau bertani.Kata culture juga kadang diterjemahkan sebagai "kultur" dalam bahasa Indonesia.

Clyde Kluckhohn (1953) dalam Budhisantoso (1994:4) mencoba mengajukan definisi kebudayaan antaralain: sebagai keseluruhan cara hidup yang dianut oleh suatu kelompok sosial; kebiasaan yang diperoleh dengan cara belajar; cara berpikir, berperasaan, dan berkepercayaan; abstraksi dari tingkah laku sosial; seperangkat pedoman untuk memecahkan masalah; mekanisme kontrol untuk mengatur tingkah laku secara normatif; ataupun seperangkat cara untuk menyesuaikan diri dengan lingkungan dalam arti luas maupun dengan sesama manusia.

Menurut Koentjaraningrat (1990:203-204) kebudayaan memiliki beberapa unsur yang terkadung di dalamnya, antaralain: (1) Kesenian, (2) Sistem teknologi dan peralatan hidup, (3) Organisasi sosial, (4) Bahasa, (5) Sistem mata pencaharian hidup dan sistem ekonomi, (6) Sistem pengetahuan, dan (7) Sistem religi.Kebudayaan menjadi milik masyarakat yang dipergunakan secara bersama 
sebagai pedoman atau kerangka acuan warga masyarakat yang bersangkutan dalam berbagai tingkah laku yang bertalian dengan upaya untuk memenuhi kebutuhan hidupnya. Kendati dalam kenyataan empirispada tingkat individu dimungkinkan terjadi penyimpangan sikap dan tingkah laku sebagai akibat pengetahuan kebudayaan yang dimiliki (Suparlan, 1990 dalam Triyanto, 2015), namun demikian, dengan jelas sikap dan tingkah laku sosial anggota suatu masyarakat itu tidak bebas dari kebudayaan yang pada hakikatnya mengandung nilai-nilai budaya yang berasumsi tentang keadaan yang diinginkan atau sebaliknya, anggapan tentang apa yang baik dan buruk, serta anggapan apa yang harus dilakukan dan apa yang harus dihindarkan (Budhisantoso, 1994:5).

Tanpa kebudayaan, suatu masyarakat tidak memiliki identitas yang jelas.Keberadaannya selain bernilai sebagai simbol identitas, juga bernilai sebagai sistem tata kehiduan dalam bersikap dan bertingkah laku untuk memenuhi kebutuhan hidupnya. Kebudayaan bergantung pada keserupaan secara umum, dalam penafsiran secara bermakna oleh para anggota terhadap apa yang terjadi di sekitar mereka dan keserupaan dalam cara memahami mereka tentang dunia. Hal ini karena setiap kebudayaan merupakan suatu yang bersifat otonom, unik, dan memiliki bermacam-macam nilai khas yang membedakannya dengan kebudayaan lainnya (Lindholm dalam Triyanto, 2015).

\subsubsection{Musik Tradisi}

Sedyawati (1981:48) menyatakan tradisi dapat diartikan sebagai segala sesuatu yang berkaitan dengan tradisi, sesuai dengan kerangka, atau pola-pola, 
atau bentuk, maupun penerapannya yang selalu berulang, juga istilah tentang tradisi sering kali diartikan dengan pengertian kuno, atau segala sesuatu yang bersifat luhur sebagai warisan nenek moyang. Tradisi mengarah pula kepada halhal yang berkaitan dengan adat, kebiasaan, ajaran, padangan hidup, serta kebiasaan yang hingga kini masih terus diturunkan antar generasi dari nenek moyang terdahulu.

Musik tradisi adalah musik yang telah terpadu dengan hidup dan kehidupan masyarakat tertentu selama beberapa generasi (Sampurno dalam Ejawati, 1998:14).Pada umumnya, musik-musik tradisional tidak diperhatikan dan tidak diketahui siapa penciptanya, sehingga diakui sebagai milik bersama daerah musik tersebut berada. Musik tradisi memiliki tiga sifat khas (Soemarsono, 1993:67 dalam Triyanto, 2015), yaitu: (1) Sederhana: dilihat dari segi alat-alatnya dan perlengkapannya, musik tradisional sangat sederhana dalam bentuk pembuatan dan bahan yang digunakan untuk instumennya. (2) Spontan: dalam pementasannya, musik tradisional dapat dilakukan secara mendadak tanpa persiapan latihan yang benar-benar serius. Bentuk pementasan musik tradisional diikuti dengan improvisasi, namun tetap berpegang pada corak musik aslinya. (3) Komunikatif: musik tradisional merupakan musik hasil cipta masyarakat yang lahir sesuai dengan keadaan dan kehidupan masyarakat. Musiknya begitu mudah diterima dan dipahami, sehingga masyarakat akan dengan mudah dapat menerima atau menyenangi musik ini.

Musik tradisi juga memiliki beberapa ciri, Mustopo (dalam Ejawati, 1998:15) menyebutkan ciri-ciri musik tradisional antara lain: (1)Berkembang 
dalam suatu komunitas, (2)Menggambarkan kepribadian komunal atau masyarakat setempat, (3)Menyuarakan semangat dan spirit kebersamaan masyarakat bersangkutan, (4)Senantiasa bersangkutan dengan kehidupan seharihari anggota komunitas, (5)Bersifat fungsional, dan (6)Proses pewarisannya tidak mengenal cara-cara tertulis.Kesenian tradisi Betawi sendiri memiliki sifat khas yaitu, sifat kepolosannya (tidak ada istilah porno dan kasar) yang mencerminkan sifat masyarakatnya, dan dalam hal ini juga memberikan pengertian bahwa bahasa Betawi bukanlah bahasa yang rendah (Dinas Kebudayaan Provinsi DKI Jakarta, 2000:70).

Berdasarkan uraian di atas, dapat disimpulkan bahwa musik tradisi adalah musik yang dimiliki oleh suatu daerah yang diturunkan antar generasi, dimana dalam musik yang diwariskan tersebut, tercermin kehidupan masyarakat pemiliknya. Musik tradisi hanya akan dapat terus bertahan apabila proses pewarisan terus dilakukan antar generasi. Generasi tua harus tetap giat menurunkan tradisi tersebut kepada generasi muda.Selain itu, peran masyarakat setempat, dan kondisi lingkungan daerah tersebut menjadi sangat berpengaruh terhadap kelestariannya.

\subsubsection{Gambang Kromong}

Gambang Kromong merupakan musik tradisi Betawi yang hingga hari ini masih terus eksis keberadaannya.Gambang Kromong lahir akibat kedatangan kaum Tionghoa ke Batavia.Gambang Kromong juga merupakan musik tradisi yang paling merata penyebarannya dalam wilayah budaya Betawi, baik di wilayah 
DKI Jakarta maupun wilayah sekitarnya.Dalam hal penyebarannya, lebih banyak penduduk keturunan Cina di wilayah Betawi setempat, maka semakin banyak pula ditemui grup-grup orkes Gambang Kromong.Hal ini disebabkan oleh musik Gambang Kromong yang mulanya dibawa oleh penduduk keturunan Tionghoa yang tinggal di wilayah Betawi (Ruchiat, Wibisono, Syamsudin, 2003:20).

Orkes Gambang Kromong tampak menjadi perpaduan yang serasi antara unsur budaya Cina dengan unsur budaya pribumi.Akulturasi budaya dalam Gambang Kromong dapat terlihat melalui beberapa instrumen yang digunakan dalam gamelan Betawi tersebut, misalnya: instrumen gesek dan tiup dari Cina(sukong, tehyan, kongahyan, bangsing), instrumen gendang dari Sunda, dan instrumen gambang, kromong, kempul, kecrek, serta gong dari Jawa. Adapun instrumen-instrumen lainnya penyusun orkes Gambang Kromong seperti suling, ningnong, kemor, gambang besi, dan dol (Ruchiat, Wibisono, Syamsudin, 2003:20)

Sebutan Gambang Kromong diambil dari nama dua buah instrumen perkusi yaitu gambang dan kromong. Instrumen gambang berbentuk susunan bilahan yang terbuat dari kayu suangking, huru batu, atau kayu jenis lain yang empuk bunyinya bila dipukul. Jumlah bilah yang menyusun alat gambang sebanyak 18 buah.Sedangkan kromong adalah alat perkusi yang terbuat dari besi atau perunggu yang berbentuk pencon disusun sebanyak 10 buah.Seperti halnya musik Tionghoa dan kebanyakan musik Timur yang lain, Gambang Kromong hanya memakai lima nada (pentatonis), yang masing-masing mempunyai nama dalam bahasa Tionghoa, yaitu: 
liuh 六 $=$ sol

$\mathrm{u}$ 五 $=1 \mathrm{a}$

siang 上 $=$ do

che 叉 $=$ re

kong $工=\mathrm{mi}$

Tidak ada nada $\mathrm{fa}=\mathrm{f}$ dan $\mathrm{si}=\mathrm{b}$ seperti dalam musik diatonis, yakni utamanya musik Barat. Larasnya adalah salendro yang khas Tionghoa, sehingga disebut Salendro Cina, atau ada pula yang menyebutnya Salendro Mandalungan (Kwa, 2005).

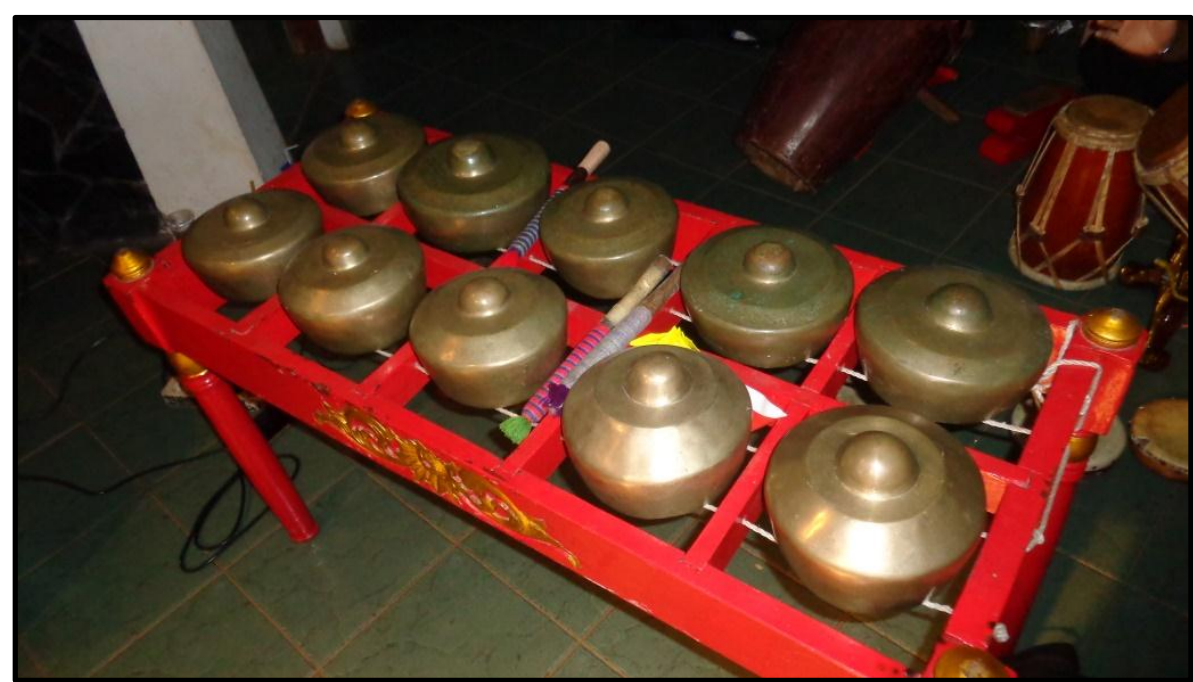

Gambar 2.2.3.1 Instrumen Kromong yang Namanya Dipakai Menjadi Nama Orkes Gambang Kromong (Foto: Marissa RH, 6 Januari 2016) 


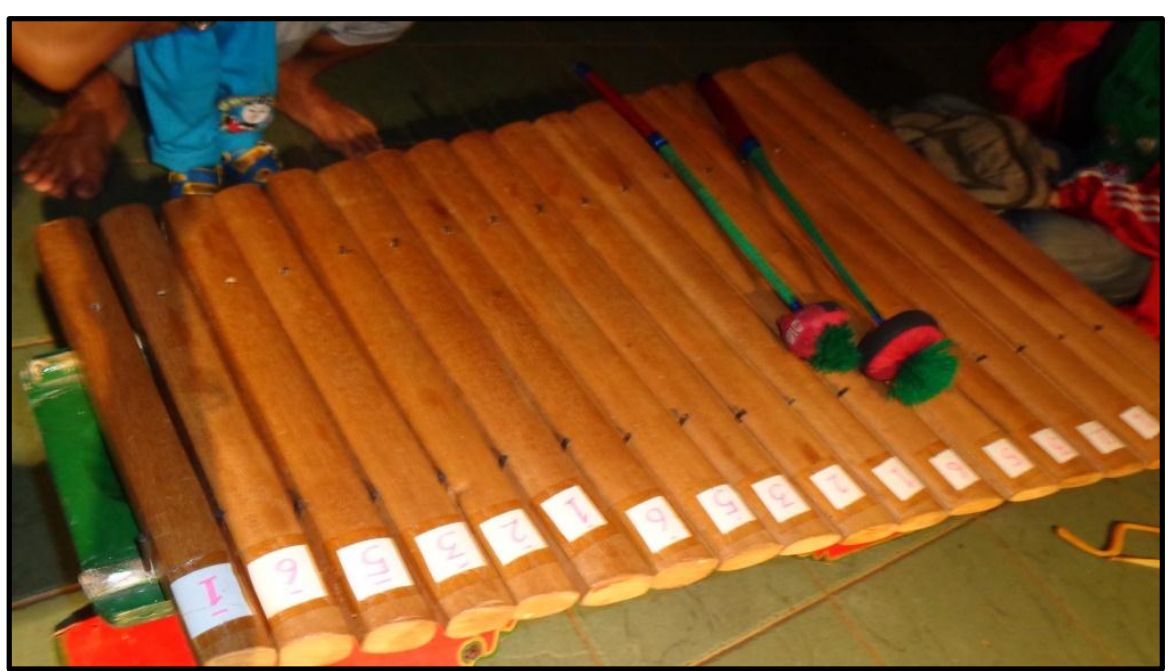

Gambar 2.2.3.2.Instrumen Gambang yang Namanya Dipakai Menjadi Nama Orkes Gambang Kromong

(Foto: Marissa RH, 6 Januari 2016)

Perpaduan unsur Cina dan Pribumi dalam orkes Gambang Kromong dapat kita saksikan pula pada perbendaharaan lagu dalam orkes ini.Kwa (2005) menguraikan ada tiga macam jenis lagu sepanjang sejarah perjalanan Gambang Kromong yaitu, lagu phobin, lagu dalem, dan lagu sayur, berikut uraiannya:

1. Lagu-lagu gambang kromong tertua yang masih diketahui jejaknya sampai sekarang adalah lagu-lagu berirama instrumentalia, dan dikenal dengan nama lagu Phobin. Lagu-lagu ini masih memakai nama Cina, suatu bukti asalusulnya yang Cina: Kong Ji Liok, Cu Te Pan, Cay Cu Teng, Seng Kiok, Ma To Jin, Ban Kim Hoa, dll.

2. Lagu Phobin ini diikuti lagu gambang kromong generasi kedua, dikenal sebagai lagu dalem: Pecah Piring, Mas Nona, Gula Ganting, Semar Gunem, Mawar Tumpah, Poa Si Li tan, Sip Pat Mo, Centeh Manis Berdiri, Gunung Payung, Tanjung Burung, dll. 
3. Jenis lagu lainnya adalah lagu sayur dengan lagu-lagunya seperti: Jali-Jali (Ujung Menteng, Pasar Malem, Jalan Kaki, Bunga Siantan etc), Stambul (Satu, Dua, Jengki, Lama, Sirih Wangi, dll), Kramat Karem (pantun dan biasa), Persi (rusak dan jalan), Centeh manis, Gelatik Ngunguk, Onde-Onde, Balo-Balo, Akang Haji, Renggong Manis, Renggong Buyut, Kue Mangkok, dll, termasuk kategori lagu pop gambang kromong ini.

\subsubsection{Kajian Sejarah}

Abdulgani (1963:174) menjelaskan bahwa sejarah ialah suatu bidang ilmu yang meneliti dan menyelidiki secara sistematis keseluruhan perkembangan masyarakat serta kemanusiaan di masa lampau, beserta segala kejadiankejadiannya dengan maksud untuk kemudian menilai secara kritis seluruh hasil penelitian dan penyelidikan tersebut, untuk akhirnya dijadikan perbendaharaan pedoman bagi penilaian dan penentuan keadaan sekarang serta arah program masa depan.

Sejarah dilakukan manusia dalam rangka memperoleh pengetahuan baru.Sebagai pengetahuan, ilmu sejarah memang mengkaji peristiwa-peristiwa masa lampau, tetapi peristiwa-peristiwa tersebut dikupas dan dianalisis dengan meneliti sebab akibatnya. Hasil analisis tersebut kemudian dirangkum kembali hingga memperoleh pengertian dalam bentuk sintesis yang dapat memberi penjelasan mengenai aspek-aspeknya, yaitu: (1) Bagaimana (deskripsi) peristiwanya? (2) Mengapa peristiwanya terjadi? (3) Kemana arah peristiwa itu 
selanjutnya? Atau sejauh mana pengaruh peristiwa tersebut terhadap waktu-waktu berikutnya? (Rustam, 1999:20)

Suatu kajian sejarah kebudayaan dapat menyoroti keseluruhan perkembangan kebudayaan disuatu daerah atau negara, namun dapat juga secara khusus memberikan sorotan terhadap salah satu aspek sejarah kebudayaan, ataupun salah satu atau beberapa komponen kebudayaan.Komponen suatu kebudayaan, seperti sistem kepercayaan, sistem pengetahuan, sistem perekonomian, sistem kesenian, sistem komunikasi, sistem organisasi sosial, dan seterusnya (Sedyawati, 2006:325).

Sejarah sosial merupakan suatu kajian sejarah yang tidak hanya menyoroti masalah pertentangan atau gerakan sosial, namun juga mengenai fenomena yang muncul dalam kehidupan masyarakat.Kajian sejarah dalam penelitian ini mengkaji mengenai pola kebudayaan masyarakat Perkampungan Budaya Betawi Setu Babakan, terutama yang memperlihatkan aspek-aspek sosial di dalamnya.Aspek-aspek yang termasuk dalam bidang ini meliputi kebudayaan, kesenian, pemikiran-pemikiran, keluarga, wadah perkumpulan seni, dan sebagainya.

\subsubsection{Konsep Enkulturasi}

Kottak (dalam Lestari, 1998:26) mengemukakan bahwa enkulturasi merupakan proses budaya yang ada, mengajarkan individu menerima normanorma dan nilai kebudayaan agar diterima sebagai anggota masyarakat. Proses enkulturasi ini, dipandang sebagai proses adaptasi budaya dimana individu- 
individu beradaptasi dengan kekuatan budaya yang melingkupinya melalui proses sosialisasi bertahun-tahun. Fathoni (2006:23) menyatakan bahwa dalam proses belajar kebudayaan oleh warga masyarakat yang bersangkutan terdapat tiga hal, yaitu proses internalisasi, proses sosialisasi, dan baru kemudian proses enkulturasi.

Menurut Triyanto (2015), enkulturasi disini dapat dilihat sebagai suatu usaha mewariskan dan/atau mentradisikan sesuatu (nilai, pengetahuan, keyakinan, norma, sikap, perilaku, keterampilan) agar menjadi kebiasaan atau adat istiadat (budaya) untuk dimiliki dan diteruskan dari satu generasi ke generasi penerusnya supaya tetap bertahan dan berkelanjutan. Muara dari ini, agar budaya tersebut tetap ada, bertahan, dan lestari.

Pewarisan secara tradisional dapat dilakukan misalnya dalam pewarisan melalui keluarga, masyarakat, lembaga adat atau lembaga agama. Sedangkan pola pewarisan secara modern dapat dilakukan dengan melalui sekolah, media massa, lembaga pemerintahan (dari pusat sampai dengan daerah), dan organisasi atau kelompok sosial (Koentjaraningrat, 1986; Ihromi 1990). Strategi pewarisan tersebut dapat ditempuh melalui jalur formal, nonformal, dan informal.Proses enkulturasi melalui jalur nonformal dapat ditemukan dalam tempat kursus, sanggar, dan sebagainya.

Menurut Rohidi (2000:28) dalam pengertian pewarisan kebudayaan senantiasa terkandung tiga aspek penting, yaitu bahwa: 1) Kebudayaan dialihkan dari satu generasi ke generasi lainnya, dalam hal ini kebudayaan dipandang sebagai suatu warisan atau tradisi sosial. 2) Kebudayaan dipelajari, bukan 
dialihkan dari keadaan jasmani manusia yang bersifat genetik. 3) Kebudayaan dihayati dan dimiliki bersama para warga masyarakat pendukungnya.

Berkaitan dengan pewarisan yaitu pelestarian kesenian tradisional menurut Sedyawati (2014:186) mengatakan bahwa: upaya pelestarian kesenian tradisional ditujukan terutama untuk mempertahankan apa yang telah menjadi milik budaya tertentu, maka upaya pengembangan yang bertujuan untuk lebih jauh membuat tradisi yang bersangkutan tidak saja hidup melainkan juga tetap tumbuh. Pelestarian dan pengembangan merupakan dua kegiatan yang tidak dapat dipisahkan atau berjalan sendiri-sendiri, sebab pelestarian artinya mempertahankan nilai-nilai tradisi yang ada guna dilakukan pengembangan untuk mempertahankan dalam berkembangnya zaman.

Proses pewarisan unsur-unsur budaya mempunyai sarana atau saluransaluran dalam rangka pembudayaan kepada generasi muda oleh generasi tuanya. Sarana saluran yang umum dijumpai dalam suatu masyarakat, antara lain lingkungan keluarga, masyarakat, sekolah, lembaga pemerintahan, perkumpulan, institusi resmi dan media massa. Terkait dengan pernyataan tersebut C.Kluckhohn (dalam Mulanto, 2015) menyatakan bahwa:

Nilai-nilai budaya, merupakan tingkah laku yang harus dipelajari dan disampaikan dari suatu generasi ke generasi berikutnya. Proses belajar budaya ini lebih dikenal dengan sosialisasi atau enkulturasi atau disebut pembudayaan, aktivitasnya dapat dilakukan melalui pembelajaran baik di sekolah formal maupun di luar sekolah. Supaya dapat dimaknai secara baik maka pembelajarannya harus mampu mengembangkan berbagai sarana yang dapat diandalkan agar dapat berinteraksi dengan lingkunganya sesuai dengan identitas alaminya. 


\subsection{Kerangka Berpikir}

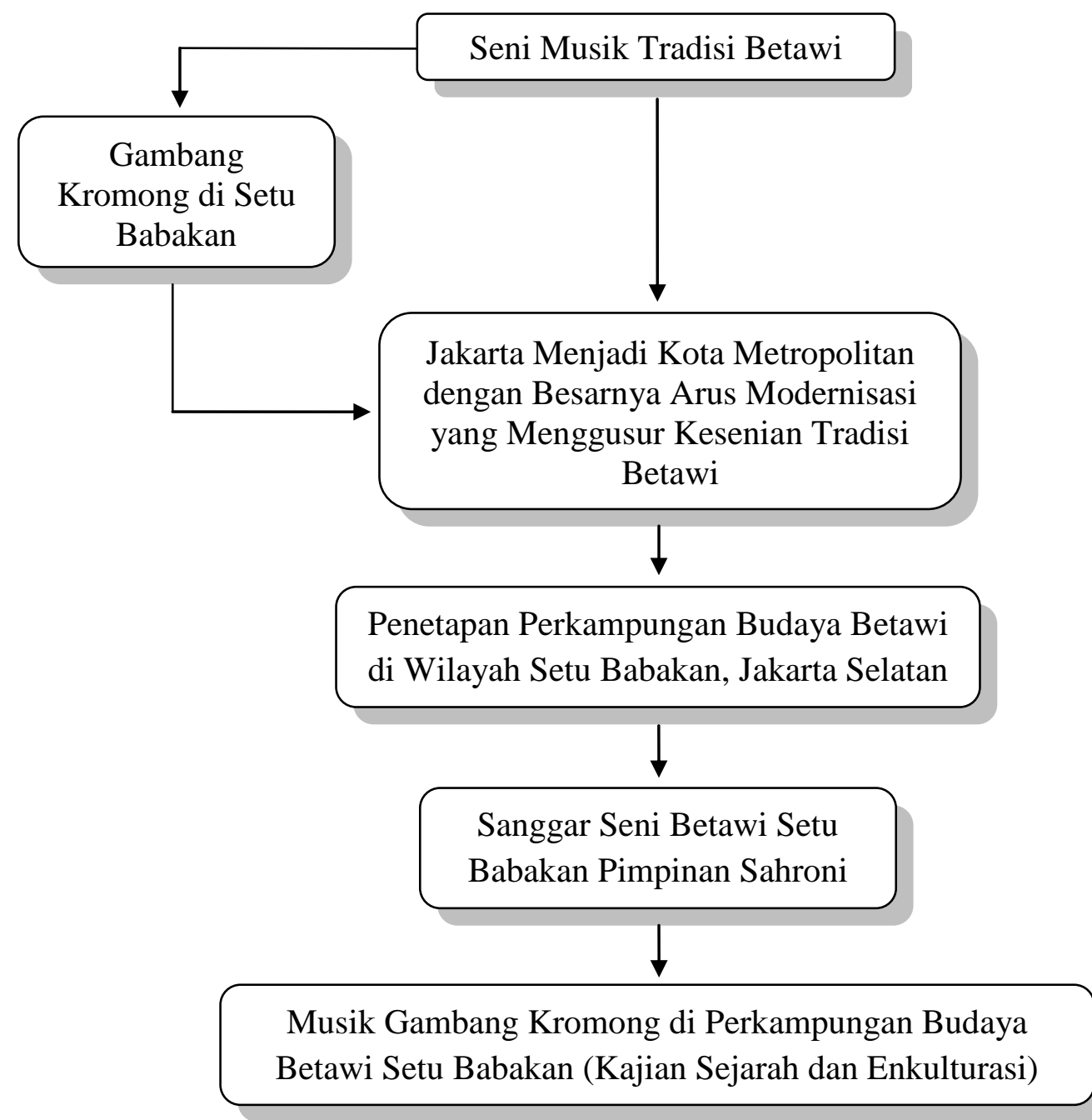

Kebudayaan merupakan salah satu hasil dari perkembangan hidup manusia, dan kebudayaan sendiri sangat erat hubungannya dalam kehidupan manusia, karena kebudayaan merupakan pengertian global kegiatan sekelompok manusia dilihat dari sudut pandang manusia sebagai mahluk yang sosial. Setiap kelompok masyarakat mempunyai karakteristik yang berbeda dengan kelompok masyarakat lainnya, baik dilihat secara fisik, ras, tempat tinggal atau 
lingkungannya, wilayah kekuasaan, kebiasaan (habit), bahasa, adat dan istiadat, suku, kepercayaan, tata nilai, kesenian, norma, hukum, sumber daya manusia, sumber daya alam, sistem pemerintahan, teknologi dan politik.

Bangsa Indonesia dengan ke-Bhineka Tunggal Ika-annya jelas memiliki beragam kebudayaan dari masing-masing suku bangsanya.Kesenian tradisi sebagai bagian dari kebudayaan Indonesia, kita ketahui telah menjadi penarik perhatian yang khas dari bangsa kita bagi mata dunia.Etnis Betawi sebagai salah satu suku bangsa Indonesia, juga memiliki kesenian tradisi yang khas dari wilayahnya sendiri.Salah satu kesenian tradisi Betawi yang hingga kini masih terus mampu bertahan di tengah maraknya modernisasi, adalah orkes Gambang Kromong.

Dalam hal pemertahanan kesenian tradisi Gambang Kromong di era moderniasasi, apalagi di tengah kondisi Jakarta sebagai Ibukota Negara yang kini menjadi kota metropolitan, menjadikan hal ini bukanlah sesuatu yang mudah. Berbagai upaya proses enkulturasi (pembudayaan) terus dilakukan dan dikembangkan demi lestarinya kesenian ini. Pihak pemerintah daerah DKI Jakarta dan masyarakat pendukung adalah pihak yang turut bertanggung jawab dalam pelestarian Gambang Kromong.Salah satu upaya pelestarian budaya Betawi oleh pemerintah Jakarta adalah dengan membuat suatu Perkampungan Budaya Betawi di daerah Setu Babakan,kelurahan Srengseng Sawah, kecamatan Jagakarsa, kota Jakarta Selatan. Masyarakat sekitar Perkampungan Budaya Betawi sadar akan posisinya yang bertanggung jawab untuk berperan serta mendukung usaha pemerintah melestarikan budaya Betawi tersebut, kemudian berinisiatif 
membangun sebuah sanggar seni Betawi dengan swadaya masyarakat sebagai wadah kesenian di daerah itu. Skripsi ini selain mengangkat proses enkulturasi, disisi lain membahas pula sejarah keberadaan orkes musik Gambang Kromong yang kini berada di Perkampungan Budaya Betawi Setu Babakan Jakarta Selatan.Sehingga menjadi suatu yang padu dengan mengetahui sejarah keberadaan kesenian tradisi tersebut, sampai bagaimana enkulturasi kesenian tradisi tersebut kini terus diupayakan. 


\section{BAB III \\ METODE PENELITIAN}

\subsection{Pendekatan Penelitian}

Penelitian ini menggunakan metode penelitian deskriptifkualitatif, dimana data-data yang diperoleh dinyatakan sebagaimana adanya atau bersifat naturalistik.Data yang dikumpulkan berbentuk kata-kata, gambar, bukan angkaangka.Menurut Bogdan dan Taylor, sebagaimana yang dikutip oleh Moleong (2000:3), penelitian kualitatif adalah prosedur penelitian yang menghasilkan data deskriptif berupa kata-kata tertulis atau lisan dari orang-orang dan perilaku yang diamati.Menurut mereka, pendekatan ini diarahkan pada latar belakang individu tersebut secara holistik (utuh), tidak boleh mengisolasi individu atau organisasi ke dalam variabel atau hipotesis, tetapi perlu memandangnya sebagai bagian dari suatu keutuhan.Dengan demikian skripsi ini menghasilkan kutipan-kutipan data untuk memberi gambaran penyajian laporan.

\subsection{Sumber Data}

Menurut Lofland dan Lofland sebagaimana yang dikutip oleh Moleong dalam bukunya yang berjudulMetodologi Penelitian Kualitatif (1998:112).mengemukakan bahwasumber data utama dalam penelitian kualitatif adalah kata-katadan tindakan, selebihnya berupa data tambahan sepertidokumen dan lain-lain. Berkaitan dengan hal itu pada bagianini jelas datanya dibagi ke dalam kata-kata dan tindakan,sumber data tertulis, foto dan statistik.Bila dilihat 
dari sumber datanya, maka pengumpulan dapat menggunakan sumber primer dan sumber sekunder. Sumber primer adalah sumber data yang langsung memberikan data kepada pengumpul data, sedangkan sumber sekunder merupakan sumber yang tidak langsung memberikan data kepada pengumpul data.

Dalam skripsi ini, sumber data primer yang dikumpulkan berupa kata-kata yang diperoleh melalui wawancara dari pelatih dan para pemainGambang Kromong Perkampungan Budaya Betawi Setu Babakan, pengurus atau pengelola Perkampungan Budaya Betawi Setu Babakan.Sedangkan sumber data sekunder penelitian ini diperoleh melalui dokumen-dokumen tentang orkes Gambang Kromong Setu Babakan,dan foto-foto mengenai Gambang Kromong Setu Babakanyang bukan dari peneliti langsung.

\subsection{Teknik Pengumpulan Data}

Pengertian teknik pengumpulan data menurut Arikunto (2002:134) adalah cara-cara yang dapat digunakan oleh peneliti untuk mengumpulkan data, di mana cara tersebut menunjukan pada suatu yang abstrak, tidak dapat di wujudkan dalam benda yang kasat mata, tetapi dapat dipertontonkan penggunaannya. Dalam hal pengumpulan data ini, penulis terjun langsung pada objek penelitian untuk mendapatkan data yang valid, maka peneliti menggunakan metode sebagai berikut: (1) Observasi, (2) Wawancara, (3) Dokumentasi dan studi dokumen. 


\subsubsection{Observasi}

Observasi adalah kegiatan pengamatan terhadap suatu objek.Adapun ikhtisar alasan metodologis penggunaan observasi/pengamatan ialah: mengoptimalkan kemampuan peneliti dari segi motif, kepercayaan, perhatian, perilaku tak sadar, kebiasan, dan sebagainya; pengamatan memungkinkan pengamat untuk melihat dunia sebagaimana yang dilihat oleh subjek penelitian, hidup pada saat itu, menangkap arti fenomena dari segi pengertian subjek, menangkap kehidupan budaya dari segi pandangan dan anutan para subjek pada keadaan waktu itu; pengamatan memungkinkan peneliti merasakan apa yang dirasakan dan dihayati oleh subjek sehingga memungkinkan pula sebagai peneliti menjadi sumber data; pengamatan memungkinkan pembentukan pengetahuan yang diketahui bersama, baik dari pihaknya maupun dari pihak subjek (Moleong, 1998:126)

Adapun jenis observasi yang penulis gunakan dalam penelitian ini berupa observasi tidak berperan serta (non participant observation), dimana penulis tidak turut aktif dalam kegiatan yang dijalankan oleh para subjek, tetapi penulis cukup melakukan pengamatan saja.Observasi ini dilakukan dengan datang ke lokasi penelitian yaitu, Perkampungan Budaya Betawi Setu Babakan Jakarta Selatan.Melalui observasi, data yang diperoleh antaralain; gambaran umum kesenian di Perkampungan Budaya Setu Babakan, lingkungan dan masyarakat pendukung di daerah Perkampungan Budaya Betawi Setu Babakan, dan kondisi para pemain orkes Gambang Kromong. 


\subsubsection{Wawancara}

Wawancara adalah percakapan dengan maksud tertentu yang dilakukan oleh dua pihak, yaitu pewawancara (interviewer) yang mengajukan pertanyaan dan yang diwawancarai (interviewee) yang memberikan jawaban atas pertanyaan (Moleong, 2000:135).Menurut Guba \& Lincoln 1981 (dalam Moleong, 1998:137) wawancara baku terbuka dibagi menjadi beberapa jenis, yaitu: wawancara oleh tim atau panel; wawancara teretutup dan wawancara terbuka; wawancara riwayat secara lisan; wawancara terstruktur dan tak terstruktur. Dalam hal wawancara tertutup, biasanya yang diwawancarai tidak mengetahui dan tidak menyadari bahwa mereka diwawancarai dan mereka tidak mengetahui tujuan wawancara.Sedangkan dalam wawancara terbuka, para subjeknya mengetahui bahwa mereka sedang diwawancarai dan mengetahui apa maksud dan tujuan wawancara tersebut.

Sesuai dengan jenis penilitian yang bersifat kualitatif, maka penelitian ini menggunakan jenis wawancara terbuka.Dengan wawancara terbuka yang bersifat semi terstruktur, dimana dalam pelaksanaannya lebih bebas bila dibandingkan dengan wawancara terstruktur, peneliti mampu menemukan permasalahan secara lebih terbuka. Pembuatan kerangka dan garis besar pokok-pokok yang ditanyakan dalam proses wawancara tetap dibuat untuk menjaga agar pokok-pokok yang direncanakan dapat tercakup seluruhnya.

Untuk memperoleh data yang diperlukan, maka dalam hal ini penulis mewawancari berbagai pihak yang memberi informasi-informasi berkaitan dengan penelitian ini.Pihak-pihak yang peneliti wawancarai diantaranya adalah 
bang Sahroni selaku ketua sanggarseni Betawi Setu Babakan, bang Andi selaku pelatih inti dari sanggar, bang Indra selaku anggota lembaga Perkampungan Budaya Betawi, dan beberapa pemain Gambang Kromong seperti bang Erik, Fadhil, dll.

\subsubsection{Studi Dokumen dan Dokumentasi}

Dokumen merupakan catatan peristiwa yang sudah berlalu.Teknik studi dokumen adalah teknik pengumpulan data yang berhubungan dengan dokumen, baik dalam bentuk laporan, statistik, surat-surat resmi, maupun cacatan harian dan semacamnya baik yang diterbitkan, maupun tidak diterbitkan (Ali, 1985:41).Dokumen bisa berbentuk tulisan, gambar, atau karya-karya monumental dari seseorang, bisa berbentuk catatan harian, foto, gambar, dan sejarah kehidupan (Sugiyono 2008:240).

Dalam hal ini, studi dokumen dilakukan dengan mengumpulkan data seperti: dokumen foto, surat kabar, serta data-data lain berkaitan dengan Gambang Kromong di Perkampungan Budaya Betawi. Hasil dari studi dokumen tersebut selanjutnya diorganisasi sedemikian rupa hingga menjadi data yang akan membantu melengkapi hasil dari observasi dan wawancara.

Dokumentasi dilakukan dengan pengambilan foto-foto terkait masalah penelitian ini.Saat ini foto sudah lebih banyak dipakai sebagai alat ukur untuk keperluan penelitian kualitatif karena dapat dipakai dalam berbagai keperluan (Moleong, 1998:114).Dokumentasi dalam penelitian ini menghasilkan foto kondisi lingkungan Perkampungan Budaya Betawi, foto kegiatan-kegiatan rutin 
terkini yang dilakukan kelompok Gambang Kromong Setu Babakan, dan sebagainya.

\subsection{Teknik Pemeriksaan Keabsahan Data}

Penelitian kualitatif (khususnya naturalistik) agar menjadi penelitian yang terdisiplin/ilmiah maka, data/dokumen yang diperoleh perlu diperiksa keabsahannya.Dalam menguji keabsahan suatu hasil penelitian, secara konvensional akan dipertanyakan apakah hasil yang didapat sudah memenuhi validitas, reliabilitas, dan objektivitas penelitiannya.Jika hasil yang didapat berubah-ubah, tidak konsisten, tidak mudah ditebak, dan kurang akurat dengan angka-angka, maka hasil perolehan penelitian bisa dikatakan belum bisa diakui kebenarannya (Kuntjara, 2006:107). Oleh sebab itu akan digunakan kriteria untuk menguji keabsahan data dalam penelitian ini seturut dengan kriteria yang dinyatakanLincoln dan Guba (dalam Sumaryanto, 2014:52) yang menyarankan empat macam standar keabsahan data kualitatif, yaitu: Derajat kepercayaan (credibility), keteralihan (transferability), kebergantungan (dependability) dan kepastian (confirmability).

Dalam penelitian ini menggunakan kriteria derajat kepercayaan dalam memeriksa keabsahan datanya.Teknik pemeriksaan triangulasi dipilih oleh penulis untuk memastikan derajat kepercayaan dari data kualitatif yang diperoleh.Pada hakikatnya triangulasi merupakan pendekatan multi-metode yang dilakukan peneliti pada saat mengumpulkan dan menganalisis data. Ide dasarnya adalah bahwa fenomena yang diteliti dapat dipahami dengan baik sehingga diperoleh 
kebenaran tingkat tinggi jika didekati dari berbagai sudut pandang.Kuntjara (2006:103) menyatakan, dengan metode triangulasi peneliti mencari beberapa sumber berbeda yang dapat memberikan pandangan serta masukan-masukan penting tentang kasus yang mirip dan berhubungan satu sama lain. Dengan membandingan data yang diperoleh dengan sumber-sumber lain akan meyakinkan data yang sudah ada, atau meragukan data yang sudah didapat. Penggunaan sumber lain untuk mendukung hasil yang sudah didapat juga memungkinkan peneliti untuk dapat mendeskripsikan temuannya dengan deskripsi masalah yang kental dan mendalam.

\subsection{Analisis Data}

Analisis data merupakan upaya mencari dan menata secara sistematis catatan hasil observasi, wawancara, dan lainnya untuk meningkatkan pemahaman peneliti dengan kasus yang diteliti dan menjadikannya sebagai temuan bagi orang lain (Muhadjir, 1989:142).Penganalisisan data merupakan proses kegiatan membangun data yang diperoleh menjadi suatu kesatuan yang utuh dan bermakna. Proses analisis data dimulai dengan menelaah seluruh data yang tersedia dari berbagai sumber yaitu, wawancara, pengamatan, yang sudah tertulis dalam catatan lapangan, dokumen pribadi, dokumen resmi, gambar, foto, dan sebagainya.Kuntjara (2006:99) menyatakan, dalam paradigma penelitian kualitatif, data dilihat bukan sebagai informasi mentah yang didapat dari lapangan tetapi didapat dari hasil interaksi antara peneliti dan sumber data baik dari manusia maupun benda, dengan demikian, data merupakan konstruksi makna 
yang diperoleh dari sumber data.Disini data analisa lebih bersifat induktif daripada deduktif.Data dianalisis bukan mulai dari teori dan hipotesis, tetapi mulai dari informasi yang didapat.Menurut Kuntjara (2006:100) dalam analisis data kualitatif, yang penting ialah bahwa analisis data hendaknya bersifat induktif, generatif, konstruktif, dan subyektif sehingga mengandung interpretasi realitas subyek sendiri.Data-data tersebut sangat banyak, oleh sebab itu peneliti harus membaca, menelaah, dan mempelajari (Sumaryanto, 2002:24).

Proses analisis data ini berlangsung secara terus menerus, bukan hanya dalam suatu saat setelah penelitian dilakukan.Menganalisis data yang sekarang dengan dasar analisis data yang sebelumnya.Analisis data juga berlangsung bersamaan dengan proses pengumpulan data. Sesuai dengan jenis penelitian ini yang adalah deskriptif kualitatif, maka teknik analisis yang sesuai yaitu analisis data model deskriptif kualitatif.Langkah analisis data deskriptif kualitatif meliputi; reduksi data, penyajian data, dan verifikasi (Milles dan Huberman dalam Rohidi, 1992:17).

\subsubsection{Reduksi Data}

Reduksi data diartikan sebagai proses pemilihan, pemusatan perhatian pada penyederhanaan, pengabstrakan, dan transformasi data "kasar" yang muncul dari catatan-catatan tertulis di lapangan. Reduksi data merupakan suatu bentuk analisis yang menajamkan, menggolongkan, mengarahkan, membuang yang tidak perlu, dan mengorganisasi data dengan cara sedemikian rupa hingga kesimpulan akhirnya dapat ditarik dan diverifikasi. Reduksi data berlangsung secara terus menerus selama proyek berlangsung, bahkan sebelum data benar-benar 
terkumpul, antisipasi adanya reduksi data sudah tampak waktu penelitian memutuskan kerangka konseptual wilayah penelitian, permasalahan penelitian, dan pendekatan pengumpulan data yang dipilihnya.

\subsubsection{Penyajian Data}

Penyajian adalah sekumpulan informasi yang tersusun dan memberi kemungkinan adanya penarikan kesimpulan dan pengambilan tindakan.Penyajian yang sering digunakan dalam penelitian kualitatif adalah bentuk teks naratif yang merupakan penyederhanaan dari informasi yang banyak jumlahnya ke dalam kesatuan bentuk yang disederhanakan. Dengan pedoman analisis penyajian data, peneliti mencari informasi dan memberikan kesimpulan yang berhubungan dengan latar belakang, seperti kondisi geografis Perkampungan Budaya Betawi Setu Babakan Jakarta Selatan, asal-usul keberadaan orkes Gambang Kromong disana, dan berbagai hal terkait penelitian ini.

\subsubsection{Verifikasi Data / Penarikan Kesimpulan}

Verifikasi adalah langkah akhir dalam analisis data setelah melalui tahap reduksi dan dideskripsikan dalam bentuk sajian data. Sajian data diinterpretasi pada setiap bab atau bagian dalam mendapatkan susunan dari kesimpulan akhir yang sistematis. Data yang diverifikasi pada penelitian ini terkait dengan sejarah keberadaan orkes Gambang Kromong dan proses enkulturasi kesenian tersebut di Perkampungan Budaya Betawi Setu Babakan Jakarta Selatan. 


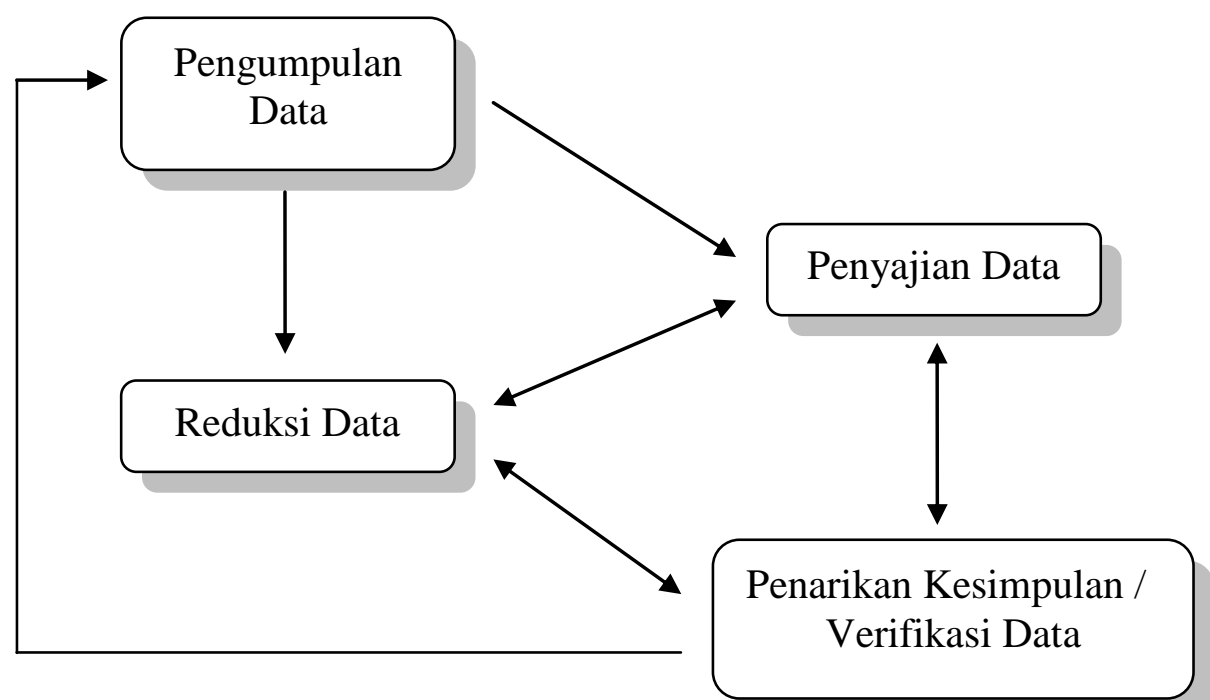

Skema Analisi Data Kualitatif Menurut Miles dan Huberman (dalam Sumaryanto, 2014:46) 


\section{BAB IV \\ HASIL PENELITIAN DAN PEMBAHASAN}

Berdasarkan hasil observasi, wawancara, studi dokumen, dokumentasi, dan proses analisis data, maka diperoleh hasil penelitian seperti diuraikan dalam bab IV ini. Pemaparan hasil penelitian secara urut akan diawali dengan gambaran umum lokasi penelitian yaitu Perkampungan Budaya Betawi Setu Babakan dan Sanggar Seni Betawi Setu Babakan Pimpinan Sahroni, kemudian diikuti dengan deskripsi fokus masalah penelitian ini yang terdiri atas sejarah musik Gambang Kromong di Perkampungan Budaya Betawi Setu Babakan, dan enkulturasi musik Gambang Kromong di Perkampungan Budaya Betawi Setu Babakan.

\subsection{Gambaran Umum Lokasi Penelitian}

\subsubsection{Perkampungan Budaya Betawi Setu Babakan}

Perkampungan Budaya Betawi Setu Babakan terletak di daerah Selatan Ibu Kota Jakarta tepatnya pada kelurahan Srengseh Sawah, Kecamatan Jagakarsa.Perkampungan Budaya Betawi adalah program pembangunan Pemerintah Provinsi DKI Jakarta dalam rangka memenuhi amanat UndangUndang Dasar 1945 (Pasal 28 ayat 2b) dan Undang-Undang Republik Indonesia nomor 29 tahun 2007-Bab V pasal 26 ayat 6, yang isinya: "Pemerintah Provinsi DKI Jakarta melestarikan dan mengembangkan budaya masyarakat Betawi serta melindungi berbagai budaya masyarakat daerah lain yang ada di daerah Provinsi 
DKI Jakarta.”. Peta lokasi Perkampungan Budaya Betawi dapat digambarkan sebagai berikut:

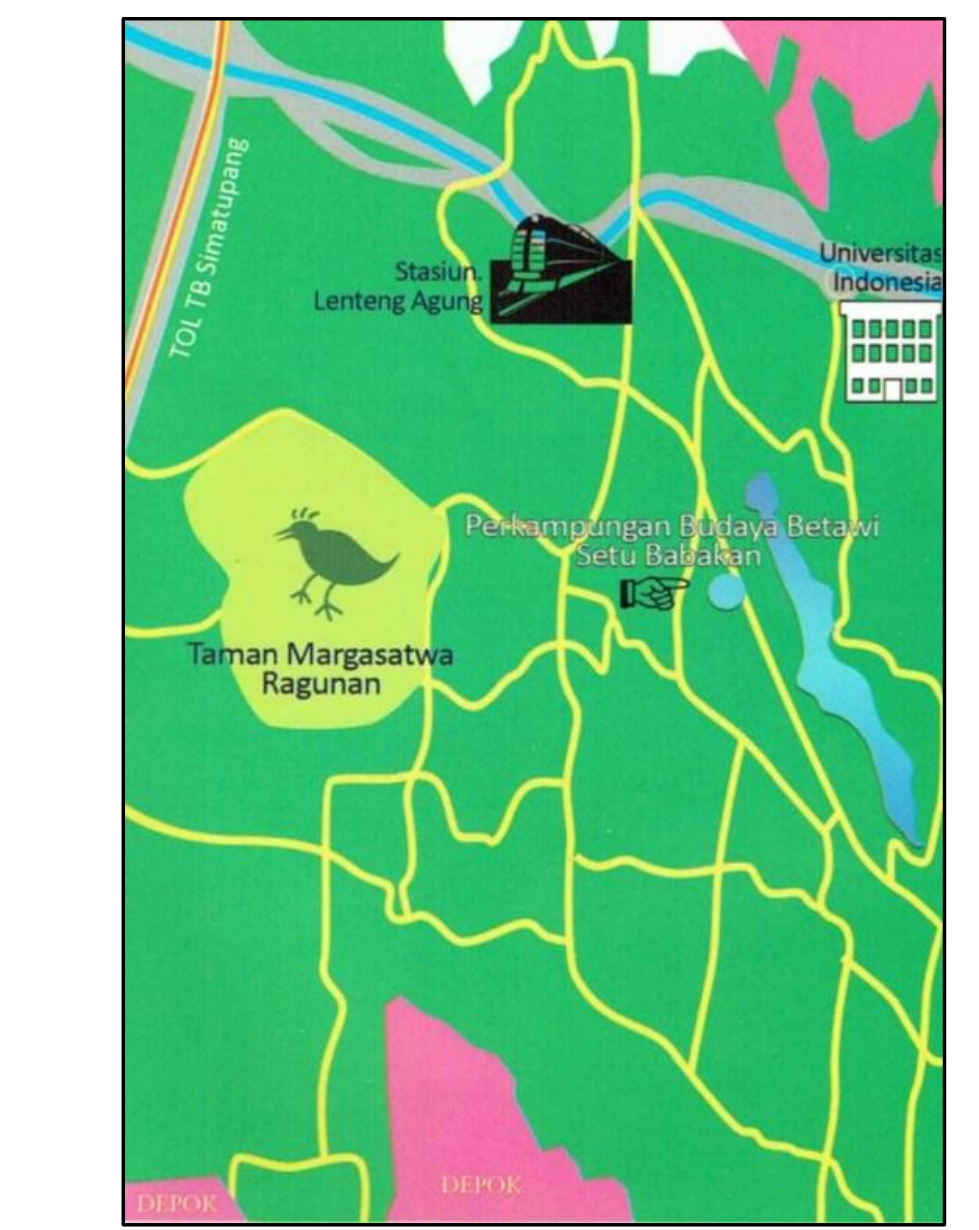

Gambar 4.1.1.1. Peta Lokasi Perkampungan Budaya Betawi (sumber: Pengelola Perkampungan Budaya Betawi)

Batas fisik wilayah Perkampungan Budaya Betawi adalah:

1. Sebelah Utara jalan Moch. Kahfi II,

2. Sebelah Timur jalan Desa Putra dan jalan Mangga Bolong Timur,

3. Sebelah Selatan jalan Tanah Merah, jalan Srengseng Sawah, dan jalan Puskesmas,

4. Sebelah Barat jalan Moch. Kahfi II. 
Bukan tanpaalasan pemerintah daerah DKI Jakarta menetapkan wilayahSetu Babakan Srengseng Sawah ini menjadi Perkampungan Budaya Betawi.Dengan sumber informasi melalui wawancara dengan Bang Indra (anggota lembaga pengelola Perkampungan Budaya Betawi) pada tanggal 25 Maret 2016, diketahui bahwa proses penetapan Perkampungan Budaya Betawi ini melalui perjalanan yang panjang dan usaha kuat dari seluruh pihak pendukung, sehingga Perkampungan Budaya Betawi ditetapkan di Setu Babakan, Srengseng Sawah, Jakarta Selatan.

Jakarta dengan segala macam budaya di tengah masyarakatnya, dalam hal ini bukan budaya betawi, dimana betawi adalah masyarakat inti kota Jakarta, hal tersebut menimbulkan rasa prihatin para tokoh-tokoh Betawi, budayawan, cendekiawan, dan para pemerhati budaya terhadap kebudayaan masyarakatnya yang terus menurun dan hampir hilang. Pada tahun 1974 saat Ali Sadikin menjabat sebagai Gubenur DKI Jakarta, dikeluarkanlah SK Gubernur 1974 yang menyatakan wilayah Condet Jakarta Timur dijadikan kawasan cagar budaya Betawi. Namun keputusan tersebut tidak serta merta merekacipta Condet, dan hasilnya regulasi kurang kuat sehingga reward and punishment tidak berjalan baik.Hal itu membuat para tokoh-tokoh pemerhati budaya tersebut kurang puas, dan sekitar tahun 1990an kembali mencari lokasi yang lebih baik, memenuhi syarat, dan representatif sebagai tempat pelestarian budaya. Dengan kesepakatan kolektif dari masyarakat, pencarian lokasi yang representatiftersebut dilakukan diseluruh wilayah DKI Jakarta yaitu, Jakarta Utara, Jakarta Pusat, Jakarta Barat, dan Jakarta Selatan (wawancara dengan bang Indra, Jumat 25 Maret 2016). 


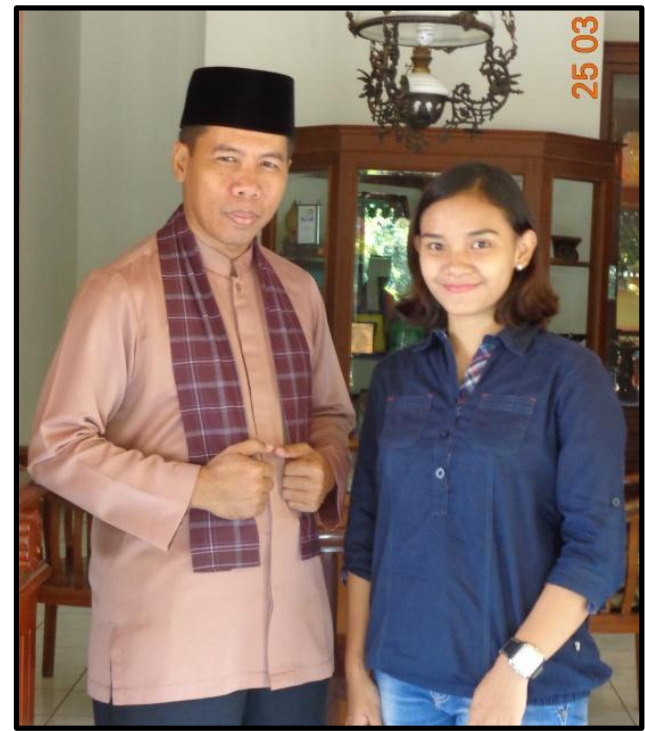

Gambar 4.1.1.2.Penulis dengan Bang Indra Sutisna (Foto: Marissa RH, 25 Maret 2016)

Jakarta Utara menjadi awal pencarian lokasi untuk pelestarian budaya Betawi, wilayahnya yang bernama Marunda diperiksa kelayakan kondisinya untuk menjadi wilayah pelestarian budaya.Wilayah Marunda terdapat Masjid AlA'lam dan Rumah Bang Pitung (begitu orang menyebutnya, walaupun sebenarnya bukan merupakan rumah asli Bang Pitung). Namun sayangnya, ditemukan fakta bahwa komunitas masyarakat Betawi di wilayah Marunda tidak banyak, temuan tersebut dirasa akan mempersulit, berat rasanya jika dibuat perkampungan Betawi sedangkan masyarakatnya tidak banyak. Pencarian lokasipun bergeser ke wilayah Jakarta Pusat, yaitu di daerah Kemayoran. Ternyata kondisi Kemayoran sudah menuju modern, kultur disana sudah tidak begitu kental, dan lokasinya lebih mendekati niaga, sehingga sama sekali tidak memenuhi kriteria. Berlanjut ke Jakarta Barat, pencarian lokasi dilakukan di daerah Kembangan. Terdapat hutan kota di daerah Kembangan, namun tidak ada 
komunitas Betawi disana, karena lokasi tersebut merupakan reka cipta total Pemda DKI Jakarta (Wawancara dengan bang Indra, Jumat 25 Maret 2016).

Sekitar tahun 1994 atau 1995, wilayah Jakarta Selatan menjadi lokasi pencarian wilayah yang dimaksudkan untuk menjadi lokasi pelestarian budaya Betawi tersebut. Terdapat sebuah setu yang bernama Setu Babakan di wilayah pinggiran Jakarta Selatan (dikatakan pinggiran karena $2 \mathrm{~km}$ dari lokasi tersebut sudah batas kota Depok Jawa Barat). Kondisi lokasi di wilayah Setu Babakan kelurahan Srengseng Sawah terlihatmemungkinkan dan cukup baik, maka diusulkan kepada Pemda sebagai tempat paling memungkinkan untuk dijadikan lokasi pelestarian budaya Betawi.Untuk mengkaji wilayah tersebut maka, pada tanggal 13 September 1997 diadakan acara "Sehari di Setu Babakan" oleh Pemda dengan leading sector adalah Suku Dinas Pariwisata Jakarta Selatan.Dalam acara tersebut dilakukan berbagai kegiatan seperti, lomba memasak sayur asem, lomba menghias perahu, cara memakan sayur asem, dll. Melalui acara "Sehari di Setu Babakan”, tampak bahwa terdapat antusias cukup tinggi dari masyarakat sekitar lokasi. Antusias masyarakat yang cukup tinggi tersebut dirasa mampu menjadi bahan dan modal yang kuat untuk kedepannya (Wawancara dengan bang Indra, Jumat 25 Maret 2016).

Tahun 1998 awalnya menjadi target eksekusi, namun karena kondisi Negara Indonesia dalam keadaan sangat tidak stabil (1998 kelabu, dll), sehingga sepanjang tahun 1998 tidak ada perkembangan atau kegiatan apapun yan dilakukan dalam hal pembangungan perkampungan budaya ini. Memasuki tahun 1999, saat kondisi Negara mulai stabil, dilanjutkanlah kegiatan penggodokan, 
lokakarya, pengkajian, dan sebagainya, hingga terjadi perbincangan dengan pihak Pemda. Tanggal 18 Agustus 2000 muncul regulasi dengan ditetapkannya Surat Keputusan Gubernur nomor 92 tahun 2000, yang isinya menyangkutpenataan Perkampungan Budaya Betawi di Kelurahan Srengseng Sawah, Setu Babakan, Jakarta Selatan. Selang waktu kurang dari satu bulan setelah dikeluarkan Surat Keputusan Gubernur tersebut, tepatnya pada tanggal 15 September 2000 maka dilakukanlah peletakan batu pertama dan dimulailah perancangan pembangunanpembangunan awal. Terdapat 4 bangunan awal yang direncanakan pada saat itu, bangunan-bangunan tersebut adalah, pintu gerbang Bang Pitung, panggung teater terbuka, wisma/guest house, dan contoh rumah adat Betawi (Wawancara dengan bang Indra, Jumat 25 Maret 2016).

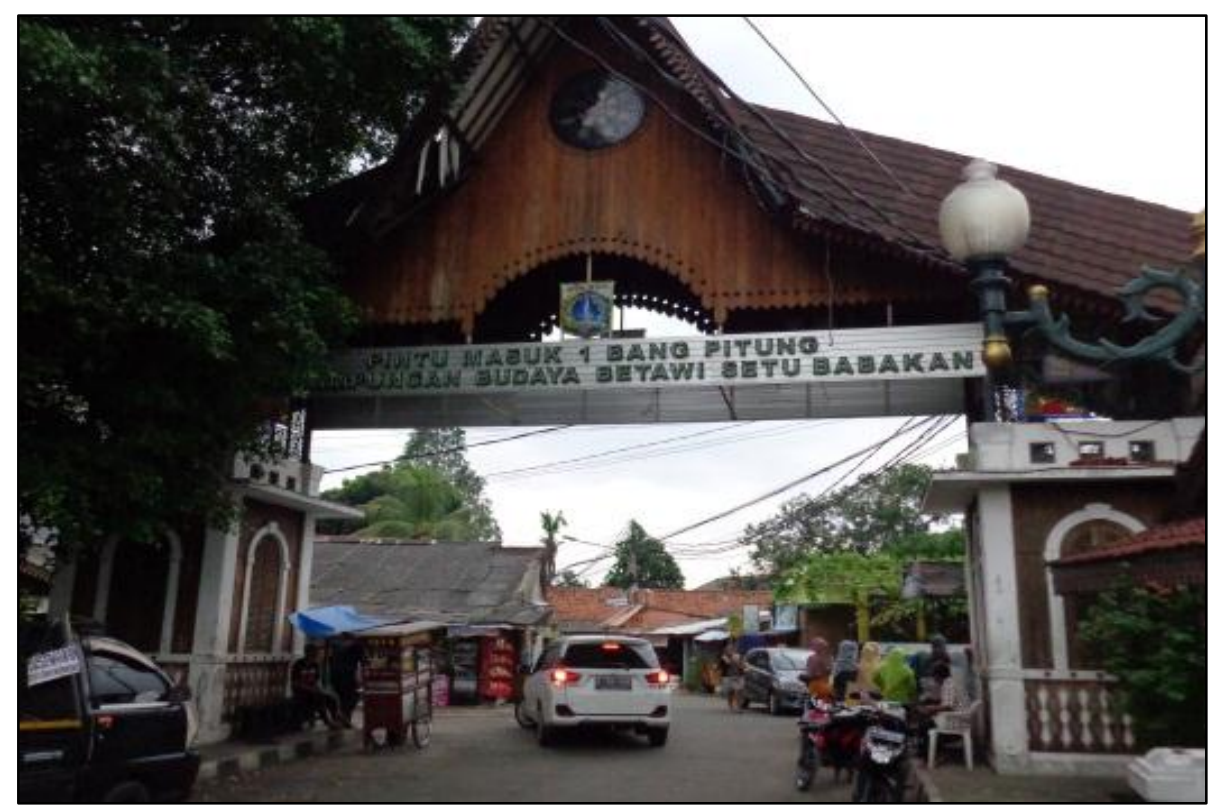

Gambar 4.1.1.3. Pintu Gerbang Bang Pitung (Foto: Marissa RH, 27 April 2016) 


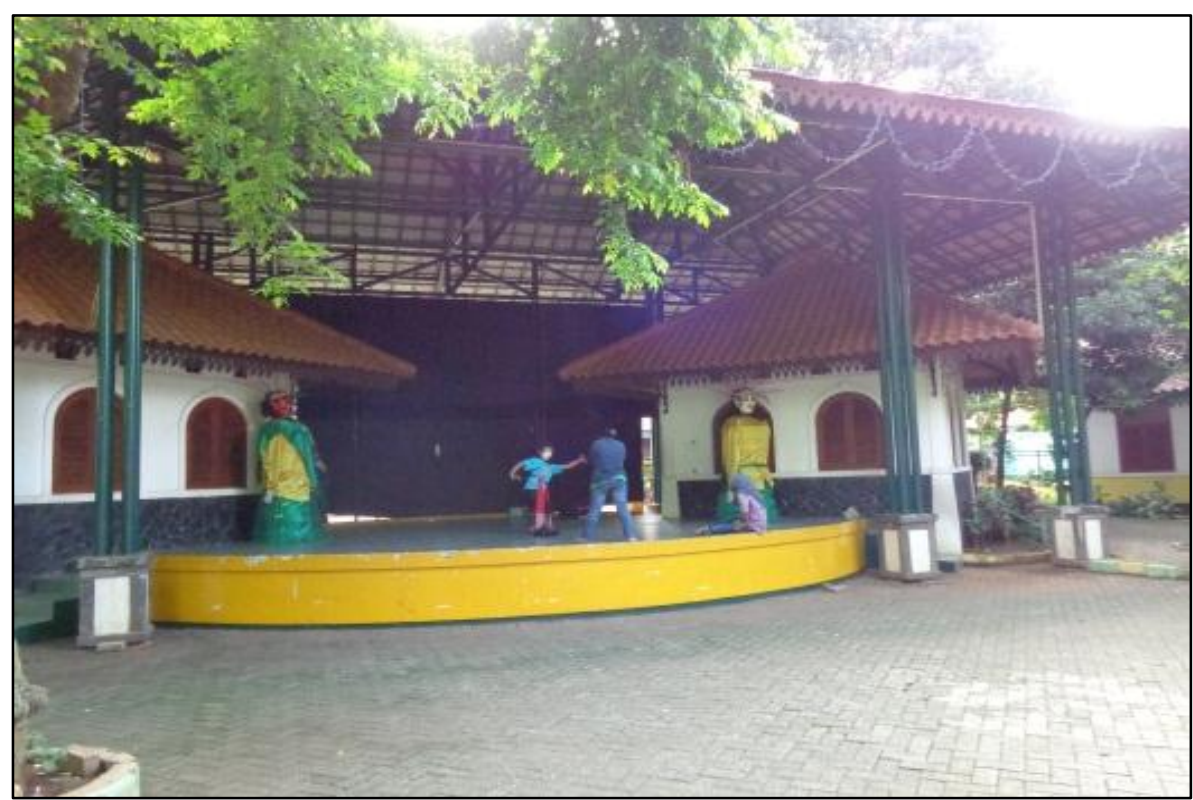

Gambar 4.1.1.4. Panggung Teater Terbuka

(Foto: Marissa RH, 27 April 2016)

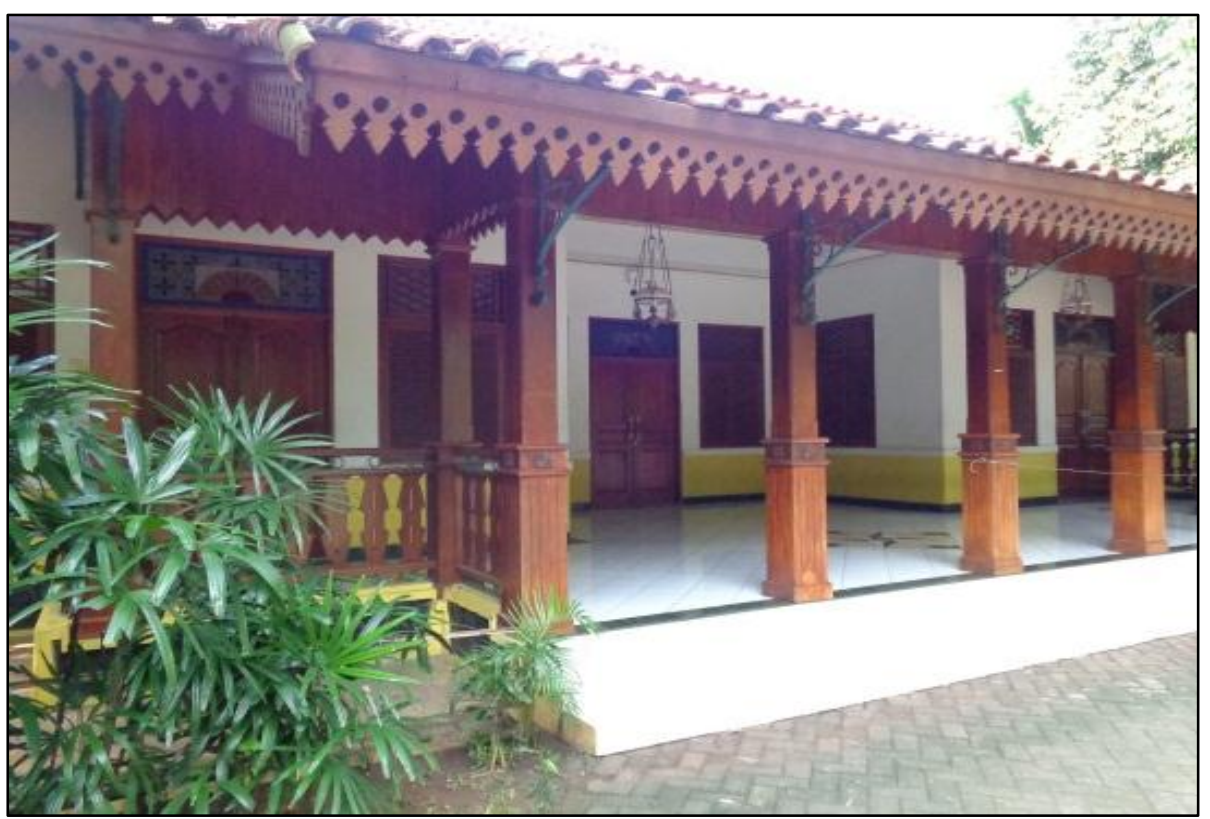

Gambar 4.1.1.5. Wisma/Guess House

(Foto: Marissa RH, 27 April 2016) 


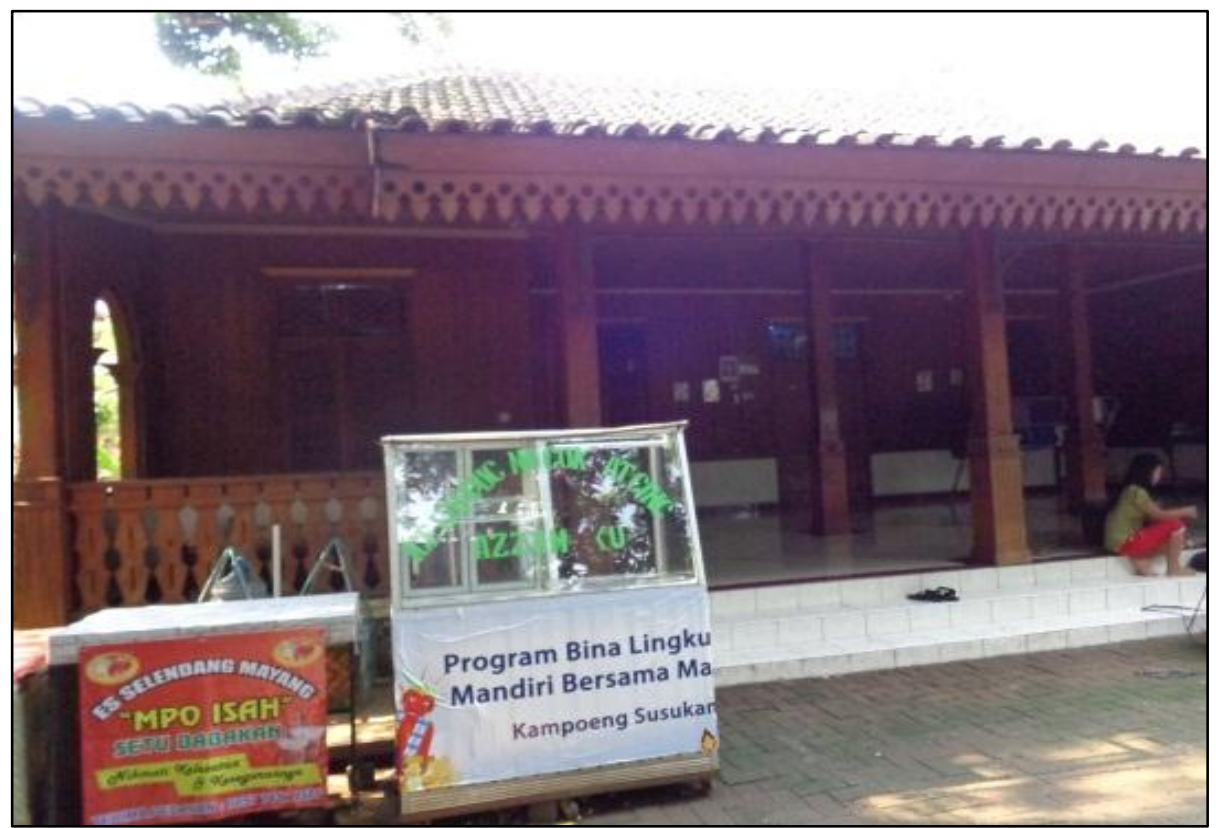

Gambar 4.1.1.6.Contoh Rumah Adat

(Foto: Marissa RH, 27 April 2016)

Tanggal 20 Januari 2001 diadakan acara peresmian Perkampungan Budaya Betawi tahap awal, dibarengi pula dengan acara halal-bihalal masyarakat Betawi.Sejak saat itulah Perkampungan Budaya Betawi Setu Babakan mulai dibuka, dan masyarakat sudah bisa berkunjung.Suku Dinas dan Dinas Pariwisata dan Kebudayaan, membantu publikasi Perkampungan Budaya Betawi ini melalui carasesekali membuat kegiatanyang lokasinya ditempatkan di Perkampungan Budaya Betawi.Seiring waktu berjalan, Perkampungan Budaya ini semakin ramai mendapat kunjungan, maka dirasa dibutuhkannya sebuah tempat pusat informasi khusus.Pada awalnya, tempat informasi dan tempat untuk menerima tamu ada di sebuah ruangan kecil di bangunan contoh rumah adat.Ruangan tersebut merupakan sebuah kamar di dalam contoh rumah adat, dan ukurannya sangat sempit. Mempertimbangkan hal tersebut, maka pada akhir tahun 2001 
dibangunlah sebuah pusat informasi Perkampungan Budaya Betawi yang dikenal dengan nama zona embrio.

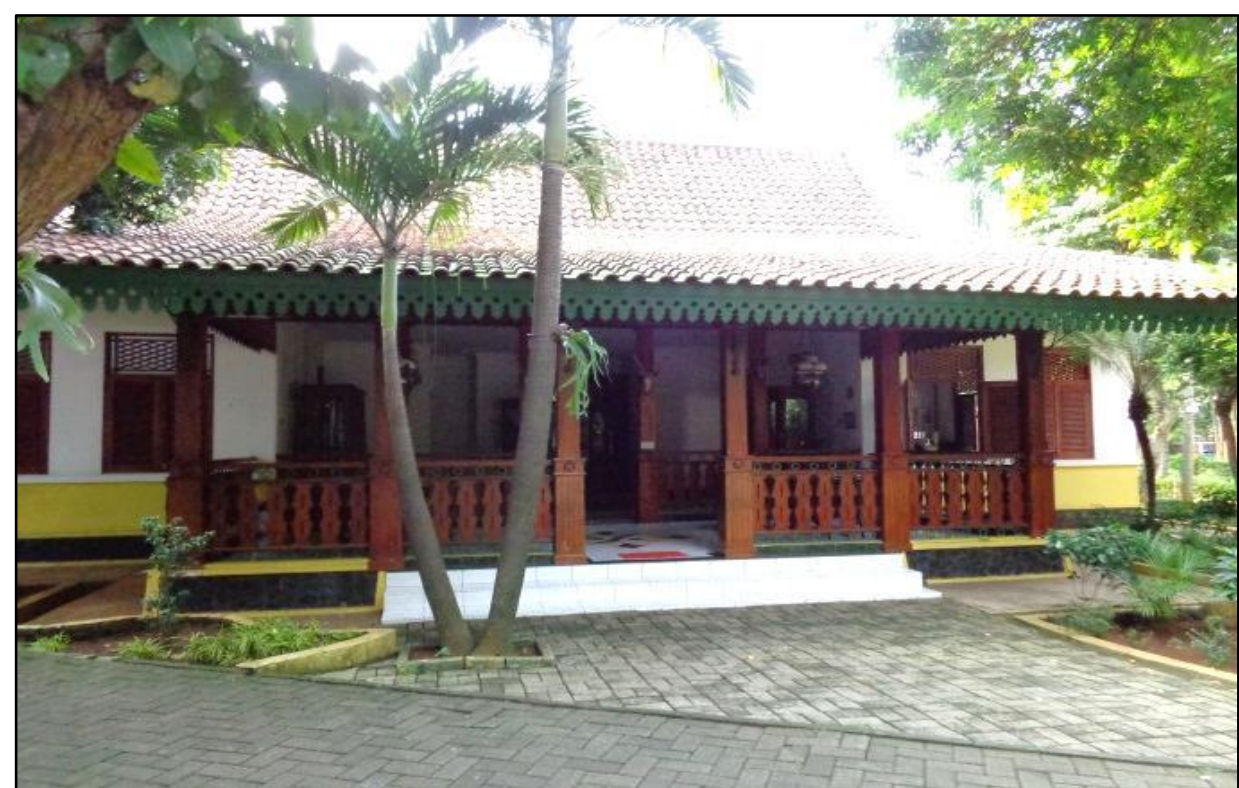

Gambar 4.1.1.7. Pusat Informasi (Embrio)

(Foto: Marissa RH, 27 April 2016)

Pada masa dimana Perkampungan Budaya Betawi mulai tenar namanya, dan perkembangannya cukup baik dan signifikan, muncul pemikiran untuk menguatkan kembali Perkampungan Budaya ini. Pemikiran tersebut muncul dari rasa ragu apabila landasan semua ini hanya dengan SK Gubernur, maka tidak menutup kemungkinan terjadi hal seperti yang menimpa wilayah Condet sebelumnya.Melalui pemikiran tersebut, dilakukan kembali penggodokan dan mengejar penguatan regulasi.Hasil dari pengejaran regulasi tersebut, tanggal 10 Maret 2005 sekitar pukul 10 pagi, terjadilah ketuk palu Peraturan Daerah nomor 3 tahun 2005 yang isinya menetapkan Perkampungan Budaya Betawi di kelurahan 
Srengseng Sawah dengan luas wilayah 289 hektar (Wawancara dengan bang Indra, Jumat 25 Maret 2016).

Dari uraian panjang tersebut, terlihat bahwa pembangunan Perkampungan Budaya Betawi dengan reka cipta, tidak dilakukan secara masif, namun bertahap dan bahkan terkesan sporadis karena tidak ada perencanaan-perencanaan yang sangat detail pada saat itu. Hingga saat ini, Perkampungan Budaya Betawi masih dalam proses pelengkapan konsep tata kelola yang belum selesai. Kini Perkampungan Budaya Betawi Setu Babakan sedang terus mengadakan pembangunan-pembangunan, seperti zona A dan zona C. Zona A sendiri akan dibuat menjadi museum, namun karena kondisi, maka untuk sementara zona A digunakan sebagai kantor pengelola kawasan Perkampungan Budaya Betawi.

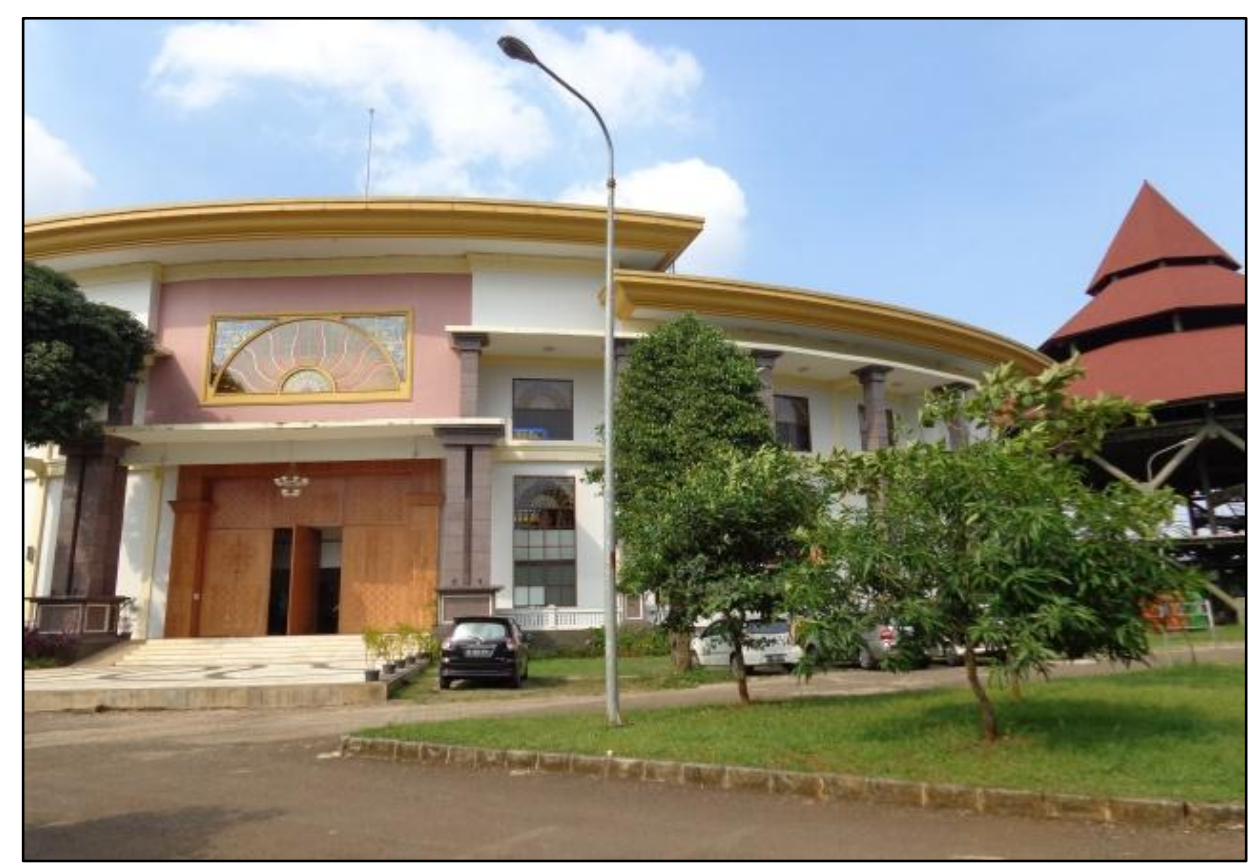

Gambar 4.1.1.7.Zona A Perkampungan Budaya Betawi yang Saat Ini Masih Dalam Proses Pembangunan

(Foto: Marissa RH, 27 April 2016) 
Menurut pernyataan dari bang Indra Sutisna, Perkampungan Budaya Betawi sendirisecara sederhana terkonsep sebagai kampung yang direka cipta bernuansa kebetawian baik fisik maupun nonfisik. Deskripsi tentang konsep Perkampungan Budaya Betawi dari bang Indra tersebut sefaham dengan pernyataan tim penyusun buku "Setu Babakan dari Penelitian ke Penelitian" (Mardani dkk, 2014) yang menyatakan "Setu Babakan merupakan satu tempat yang dibangun dengan semangat menyelamatkan, mengangkat, merayakan identitas Betawi di tengah lajunya pembangunan yang sering mengesampingkan tradisi Budaya.’.Di dalam Perkampungan Budaya Betawi tersebut terdapat Setu Babakan, Setu Mangga Bolong,dan Setu ISTN(Institut Sains dan Teknologi Nasional).Struktur lembaga pengelola Perkampungan Budaya Betawi berdasarkan keputusan Gubernur Jakarta tanggal 10 September 2014, tersusun dengan bagian-bagian yaitu ketua dan beberapa komite dibawahnya, sepertikomite tata kehidupan dan budaya, komite kesenian dan pemasaran, komite pengkajian, pelatihan, dan pendidikan, dan komitepengawasan dan pengendalian. Bagan struktur lembaga pengelola Perkampungan Budaya Betawi dapat dilihat pada bagan 4.1.1.1.

Profesi masyarakat sekitar Perkampungan Budaya Betawi terus berubah pesat sejak tahun 1980, dahulu mata pencaharian utama adalah berkebun atau bercocok tanam.Sejak adanya pemerataan pada tahun 1980, penyaluran listrik yang membaik, transportasi meluas, mulai berdiri kampus-kampus, dan urbanisasi 
masuk tidak dapat dihindari, maka bercocok tanam tidak lagi sesuai dan tidak mendukung. Masyarakat kemudian mulai banyak yang berniaga, bekerja di kantor-kantor pemerintah, kantor swasta, bidang jasa, menjadi buruh, Polri, dan hingga hari ini sudah banyak juga yang menjadi profesional seperti dokter spesialis, konsultan, dan sebagainya. Dalam keterlibatannya dengan pengelolaan Perkampungan Budaya Betawi, penerimaan pegawai akan mengutamakan masyarakat sekitar, sehingga bisa dikatakan bahwa dengan adanya Perkampungan Budaya Betawi memiliki nilai positif secara ekonomi untuk masyarakat sekitarnya (Wawancara dengan bang Indra, Jumat 25 Maret 2016). 


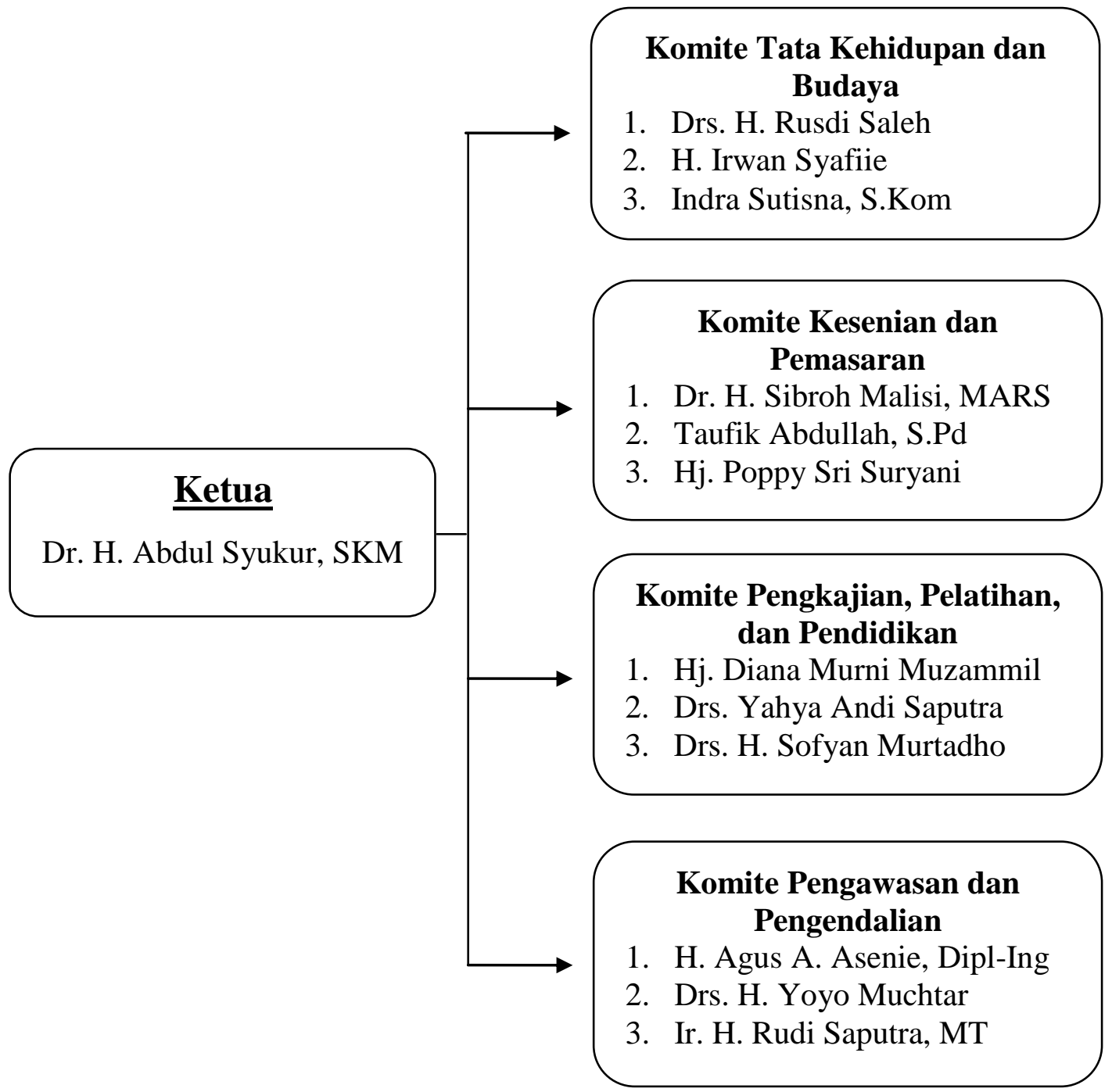

Bagan 4.1.1.1.Struktur Lembaga Pengelola Perkampungan Budaya Betawi (sumber: Lembaga Pengelola Perkampungan Budaya Betawi)

Perkampungan Budaya Betawi menjadi sangat ramai pengunjung pada saat weekend dan hari-hari libur nasional.Pengunjung dari berbagai daerah luar Setu Babakan berdatangan untuk menikmati wisata budaya, memancing, berolah raga sepeda atau jogging, atau sekedar menikmati pemandangan yang asri di tepi danau Setu Babakan.Banyak pedagang menjajakan dagangannya, yang 
membuatnya unik adalah dagangan mereka berhubungan dengan sesuatu yang khas Betawi, baik itu makanan tradisional Betawi, baju tradisional Betawi, toko souvenir yang menjual kaos-kaos bertemakan kebetawian, kaset atau dvdyang berisi album-album lagu Betawi, menjual ondel-ondel, dan sebagainya. Para pedagang makanan khas Betawi diantaranya menjual kerak telor, bir pletok, laksa, dodol, gulali, toge goreng, soto betawi dan sebagainya.

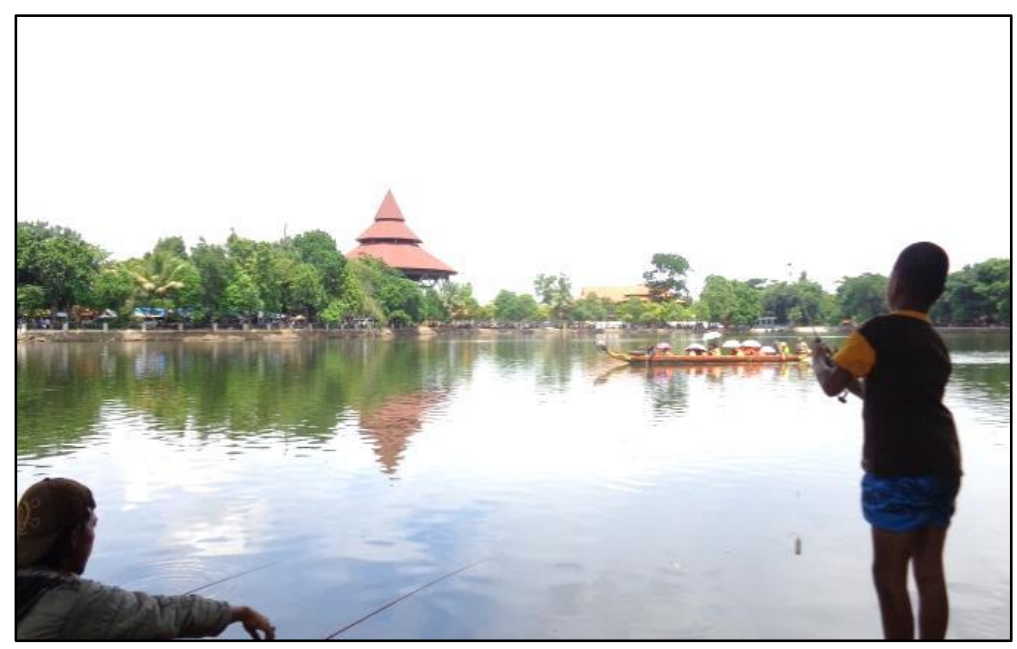

Gambar 4.1.1.9.Pemandangan dari Salah Satu Sisi Setu Babakan.Terlihat Kegiatan Rekreasi Pengunjung Berupa Memancing dan Naik Perahu.

(Foto: Marissa RH, 3 Janauari 2016)

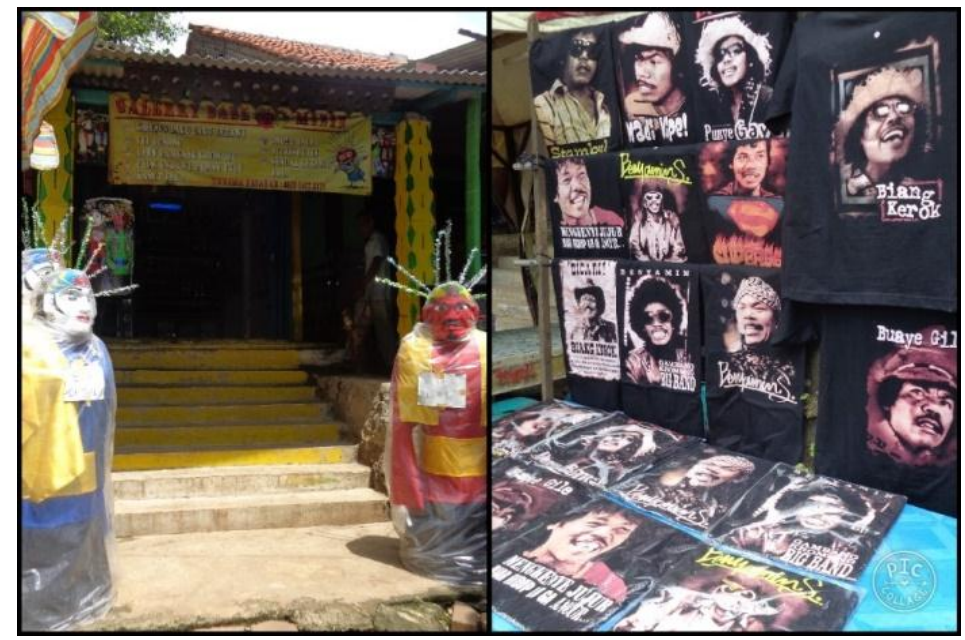

Gambar 4.1.1.10. Salah SatuToko Souvenir Khas Betawi (Foto: Marissa RH, 3 Januari 2013) 


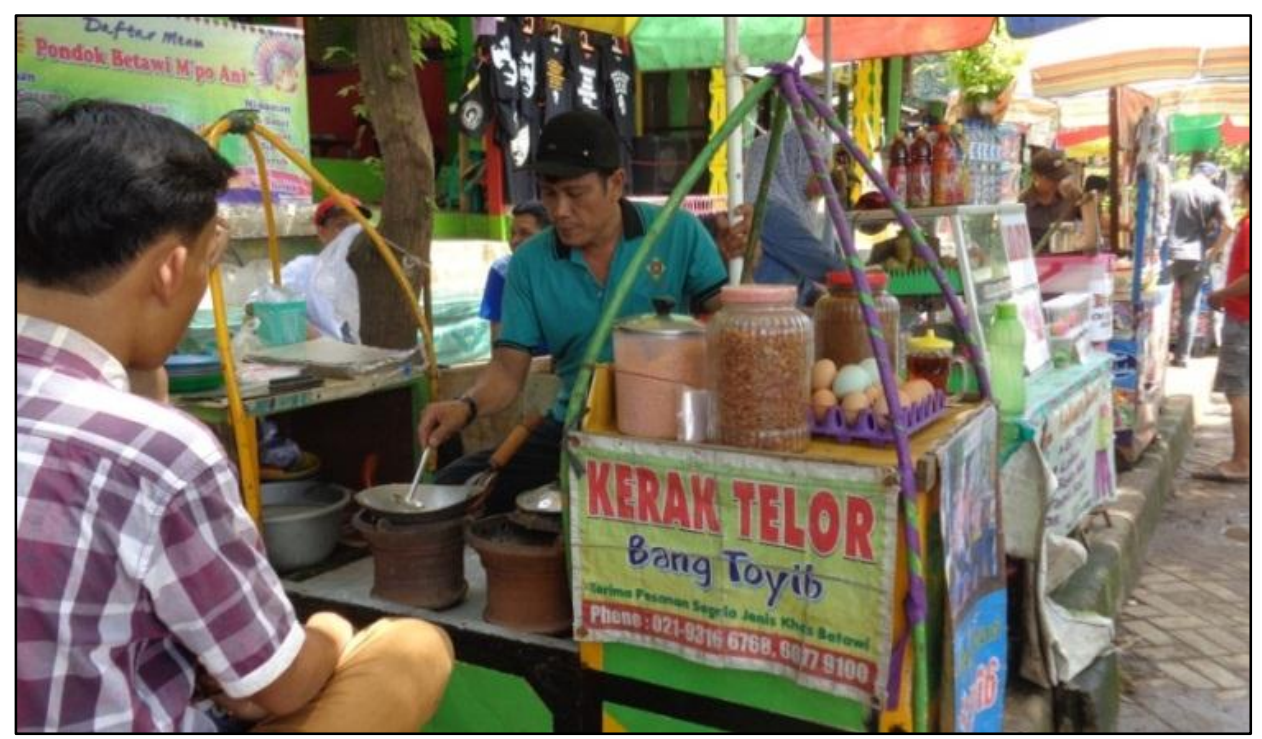

Gambar 4.1.1.11.Salah Satu Pedagang Makanan Khas Betawi "Kerak Telor" (Foto: Marissa RH, 3 Januari 2016)

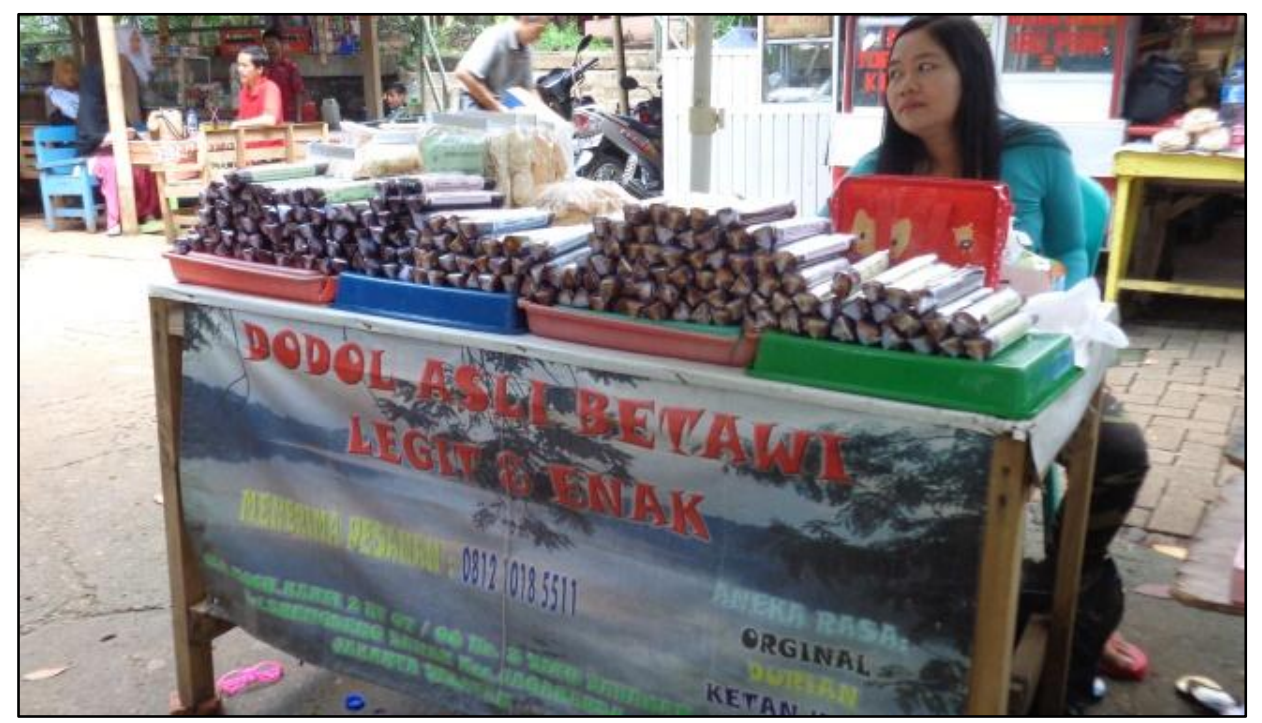

Gambar 4.1.1.12. Salah Satu Pedagang Makanan Khas Betawi "Dodol Betawi" (Foto: Marissa RH, 3 Januari 2016) 


\subsubsection{Sanggar Seni Betawi Setu Babakan Pimpinan Sahroni}

Sanggar Seni Betawi Setu Babakan Pimpinan Sahroni berdiri seiring ditetapkannya Perkampungan Budaya Betawi di wilayah Setu Babakan, Srengseng Sawah.Secara administrasi anggota sanggar ini kini sudah mencapai \pm 1000 peserta secara keseluruhan.Antusiasme masyarakat untuk mempelajari kesenian tradisi Betawi ternyata masih cukup kuat, terbukti melalui banyaknya anggota sanggar Seni Betawi Setu Babakan ini.

Pada tahun 2002 Sanggar Seni Betawi Setu Babakan resmi dibentuk atas ide dan dukungan masyarakat yang memiliki semangat tinggi untuk membuat suatu wadah kesenian tradisi Betawi di wilayah Setu Babakan. Kini Sanggar Seni Betawi Setu Babakanmembuka pelatihan seni musik tradisi Betawi (Gambang Kromong), seni bela diri Betawi silat beksi (yang baru dimulai tahun 2007), seni teater tradisi Betawi (Lenong), dan beragam seni tari tradisi Betawi.Lokasi kantor sanggar ini berada di dalam wilayah Perkampungan Budaya Betawi tepatnya di Jalan Setu Babakan nomor 35. Kantor sanggar tidak buka setiap hari, waktu buka pelayanannya mengikuti jadwal latihan, yaituhari Rabu mulai pukul 16.00, dan Minggu mulai pukul 08.00 (Wawancara dengan bang Sahroni, Rabu 23 Maret 2016)

Latihan-latihan kesenian biasadilakukan di wilayah wisatabudaya Perkampungan Budaya Betawi.Waktu latihan kesenian bisa menjadi kesempatan menarik bagi para pengunjung. Pada hari Rabu sore atau Minggu pagi saat pengunjung berkeliling wilayah Perkampungan Budaya Betawi, mereka akan disambut dengan suguhan penampilan anak-anak didik sanggar yang sedang 
berlatih. Bisa dikatakan para pengunjung akandihibur denganmenyaksikan pertunjukan mentah dari sanggar seni ini.

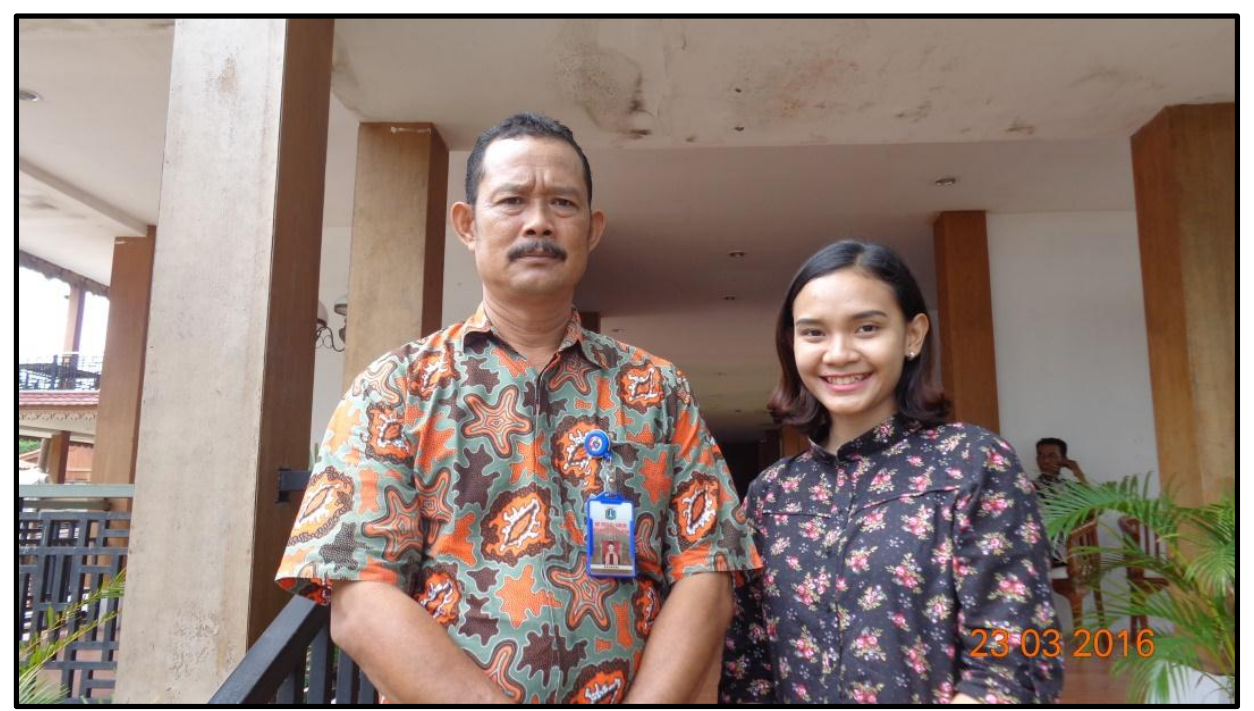

Gambar 4.1.2.1.Penulis dengan Bang Sahroni

(foto: Marissa RH, 23 Maret 2016)

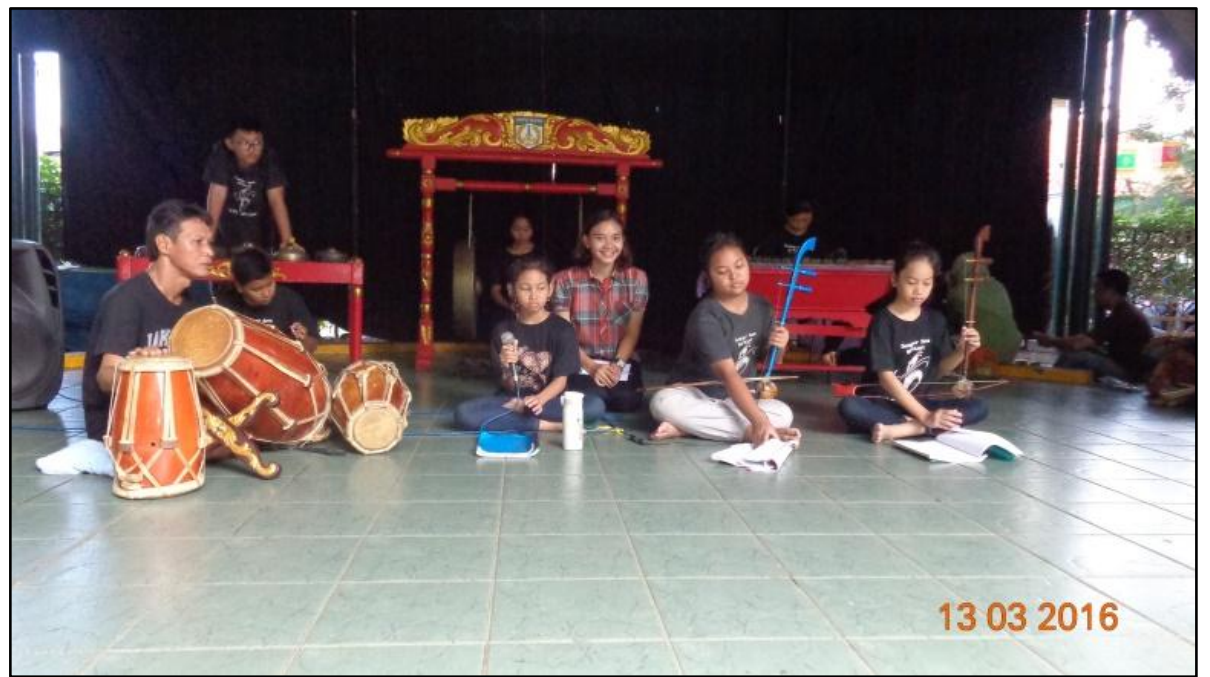

Gambar 4.1.2.2. Panggung Teater Terbuka Sebagai Lokasi Latihan Berbagai Kesenian Betawi

(foto: Marissa RH, 13 Maret 2016) 


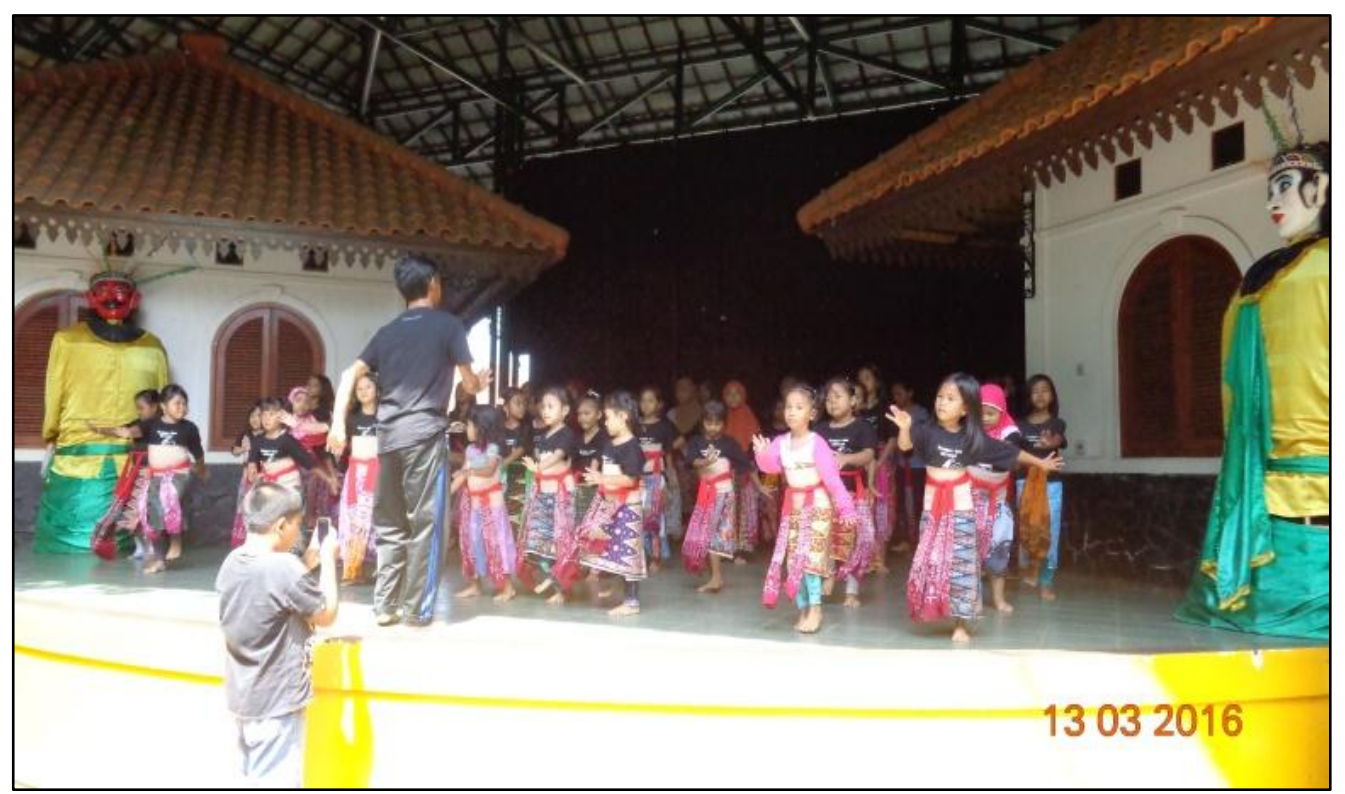

Gambar 4.1.2.3. Panggung Teater Terbuka Sebagai Lokasi LatihanBerbagai Kesenian Betawi

(foto: Marissa RH, 13 Maret 2016)

Kepengurusan sanggar yang dipimpin oleh bang Sahroni saat ini, merupakan generasi ke-2 dimana sebelumnya dipimpin oleh bapak Romi Rojali. Peserta sanggar Setu Babakan ini tidak serta merta eksklusif hanya dari penduduk asli Betawi saja.Sahroni, ketua Sanggar Seni Betawi Setu Babakan menyatakan tidak pernah menargetkan berapa umur siswa yang akan bergabung ke sanggar seni ini, asal sudah mengerti, ada niat, dan kemauan, silahkan bergabung. Sahroni juga tidak pernah menutup sanggar ini untuk peserta dari wilayah atau suku manapun, karena menurutnyaapabila hanya mengharapkan dari warga Betawi saja pasti tidak akan bisa maju.Struktur kepengurusan Sanggar Seni Betawi Setu Babakan disajikan dalam bagan 4.1.2.1. 
Sanggar Seni Betawi Setu Babakan sudah memiliki gaung cukup besar di tengah masyarakat.Banyak anak didiknya yang mencetak prestasi kesenian tingkat Provinsi DKI Jakarta maupun tingkat nasional.Tahun 2015 lalu, tari yang berkolaborasi dengan musik Gambang Kromong dari sanggar ini meraih juara 2 lomba tingkat DKI Jakarta.Waktu tampil yang cukup intens dialami oleh Sanggar Seni Betawi Setu Babakan. Untuk musik Gambang Kromong sendiri, paling tidak akan tampil satu bulan sekali, baik itu untuk acara pemerintahan, maupun acaraacara di luar seperti bermain di acara hajatan, atau di hotel-hotel untuk menghibur tamunya. Tari dan Gambang Kromong juga akan selalu menunjukan penampilannya setiap kali Perkampungan Budaya Betawi menerima kunjungan dari pihak-pihak sekolah ataupun kunjungan dari pemerintahan. Selain dari pihak sekolah dan pemerintahan, tidak jarang pula Perkampungan Budaya Betawi menerima kunjungan dari pihak-pihak luar yang menyewa tempat untuk mengadakan acara pertemuan sehari seperti gathering keluarga ataugatheringperusahaan. 


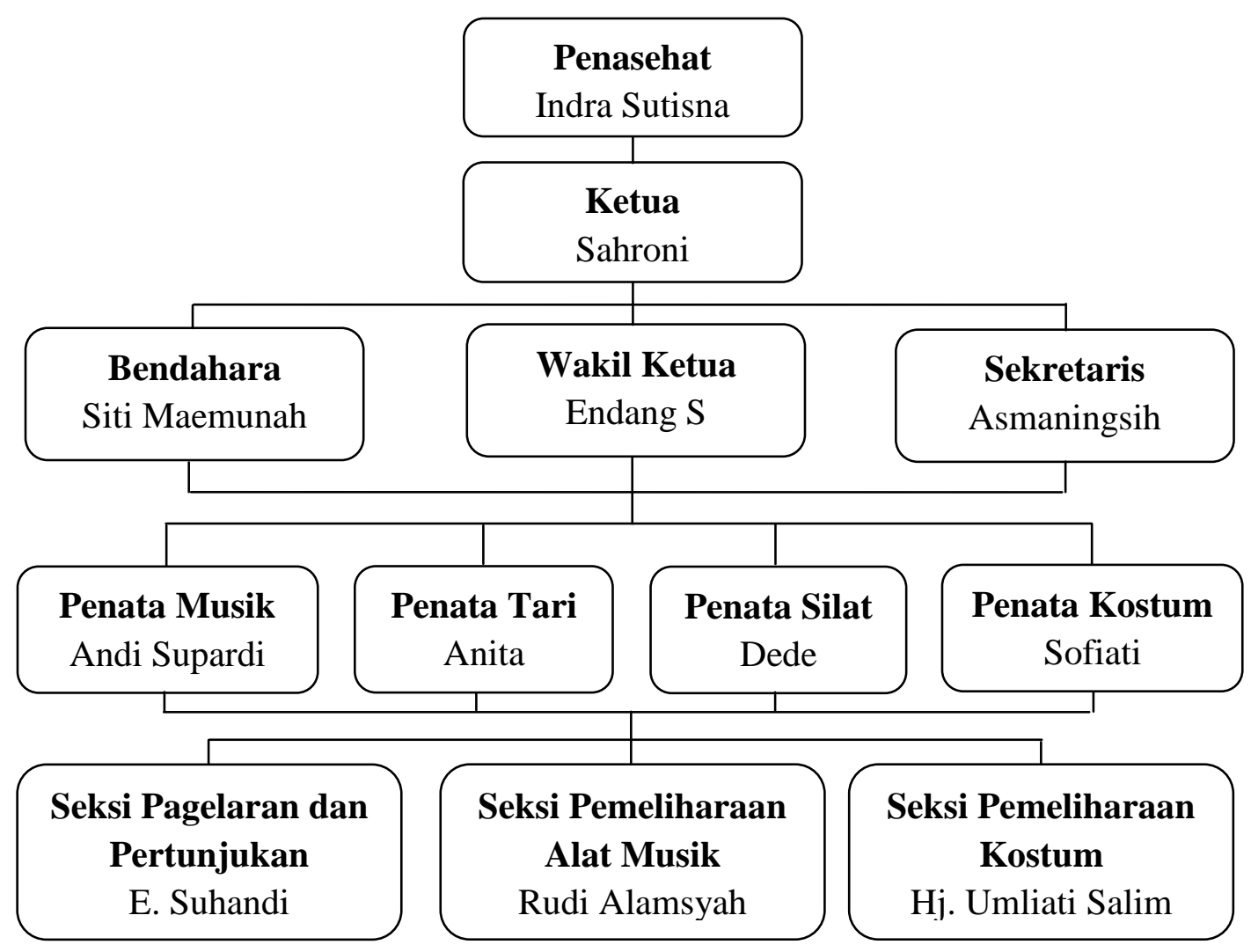

Bagan 4.1.2.1. Struktur Kepengurusan Sanggar Seni Betawi Setu Babakan (Sumber: Sanggar Seni Betawi Setu Babakan)

\subsection{Sejarah Musik Gambang Kromong di Perkampungan Budaya Betawi}

\section{Setu Babakan}

Sudah ratusan tahun etnis Tionghoa datang ke tanah air.Selain membawa misi perdagangan, mereka juga menyebarkan agama, adat istiadat dan budaya.Dari mereka ada pula yang menetap bahkan menikah dengan penduduk lokal. Karena menikah itulah, tak bisa dipungkiri secara langsung telah terjadi proses akulturasi budaya. Awal mula kedatangan etnis tionghoa di Jakarta telah terjadi sejak akhir masa kekuasaan Dinasti Tang.Mereka mulai melakukan perjalanan ke Asia Tenggara (Indonesia).Tempat yang mereka datangi adalah 
Palembang, pada saat itu merupakan pusat perdagangan Kerajaan besar Sriwijaya.Kemudian mereka datang ke pulau Jawa untuk mencari rempahrempah.Banyak dari mereka yang kemudian tinggal dan menetap di wilayah sekitar pelabuhan Pantai Utara Jawa seperti Tuban, Surabaya, Gresik, Banten (Tangerang) dan Jakarta (Chasanah, 2014:26).

Asal mula musik gambang kromong tidak bisa terlepas dari akulturasi budaya tionghoa, dalam hal ini Nie Hoe Kong yang telah memiliki andil besar dalam menghadirkan suatu perpaduan musik yang harmonis antara unsur pribumi dan unsur tionghoa.Nie Hoe Kong adalah seorang pemusik keturunan tionghoa yang tinggal di Jakarta pada pertengahan abad ke 16.Dialah yang berhasil menggabungkan beberapa alat musik yang berasal dari Cina dengan alat musik yang biasa dimainkan dalam gamelan seperti pelog dan slendro. (Chasanah, 2014:27).

Mungkin masih banyak masyarakat yang belum tahu kalau Gambang Kromong yang sempat dipopulerkan oleh Lilis Suryani di tahun 60-an dan duet Benyamin Sueb (alm) dan Ida Royani di tahun 70-an adalah sebuah musik akulturatif di Indonesia yang cikal bakalnya telah dirintis lebih dari dua abad lalu. Irama Gambang Kromong dengan tata laras salendro China kali pertama diperkenalkan oleh orang-orang Tionghoa Peranakan sebelum akhirnya mengalami percampuran dengan budaya Jawa, Sunda hingga Deli, dimana membentuk sebuah musik harmonis yang kini menjadi salah satu ciri khas Betawi (Marhadi, 2006). 
Pada tempo dulu, grup-grup kesenian tradisi Betawi menjadi primadona di wilayah DKI Jakarta dan sekitarnya. Grup teater seperti Lenong Betawi dan Topeng Betawi, grup-grup tari Betawi, grup-grup musik Betawi seperti Tanjidor, Samrah, dan Gambang Kromong, masih sangat mudah ditemui di kampungkampung, terutama dalam acara hajatan atau pesta masyarakat Betawi. Sekitar tahun 1980an dimana mulai masuk budaya baru seperti layar tancep dan DVD, membuat kesenian tersebut mulai tergeser. Kondisi memburuk ketika modernisasi semakin menguasai Ibukota, teater-teater perfilman seperti teater 21 dan sebagainya terus bermunculan, membuat keberadaan kesenian tradisi Betawi di tengah masyarakat semakin habis (wawancara dengan bang Sahroni, Rabu 23 Maret 2016).

Sebelum Perkampungan Budaya Betawi dibuat oleh Pemerintah Provinsi DKI Jakarta, di daerah Setu Babakan sudah ada beberapa grup kesenian Betawi yang dibuat oleh kelompok-kelompok masyarakat, diantarnya ada grup Lenong dan grup Gambang Kromong. Seiring berjalannya waktu dan modernisasi yang kian mewabah di Ibu Kota Jakarta, maka grup-grup kesenian tradisi tersebut mengalami kevakuman.Vakumnya grup kesenian tersebut berangkat dari pemikiran para pemain bahwa berkecimpung di dunia kesenian tradisi sudah tidak digemari lagi oleh masyarakat dan sudah tidak menguntungkan secara ekonomi (wawancara dengan bang Sahroni, Rabu 23 Maret 2016). Pemikiran-pemikiran tersebut menjadi wajar, melihat kondisi masyarakat pada waktu itu yang memang sudah terpengaruh budaya-budaya luar, membuat kesenian tradisi Betawi di wilayah Jakarta dan sekitarnya tidak lagi laku seperti dulu. 


\subsubsection{Tahun 1998}

Sebuah wadah perkumpulan masyarakat berupa kelompok tani yang berada di daerah Setu Babakan dengan nama "Setu Lestari" mendapat bantuan dari Dinas Kebudayaan berupa seperangkat alat musik Gambang Kromong. Bantuan tersebut berangkat dari adanya wacanabahwa dari Pemda DKI Jakarta, tepatnya Dinas Kebudayaan, akan membuat suatu wilayah yang akan dijadikan lokasi pelestarian budaya Betawi dengan salah satu calon lokasinya adalah daerah Srengseng Sawah, tepatnya di daerah Setu Babakan.Dengan mendapat bantuan alat musik Gambang Kromong tersebut, maka pimpinan kelompok tani "Setu Lestari” memanggil pelatih untuk melatih mereka bermain Gambang Kromong.Pelatih pada saat itu ada 3 orang, mereka adalah Pak Diman, Pak Saman (Katel), dan Pak Nisan.Pak Diman melatih tehyan, Pak Saman melatih kromong dan gambang, sedangkan Pak Nisan melatih gendang.Latihan tersebut diadakan di rumah ketua kelompok tani dan bertahan sekitar 1 tahun lamanya sebelum akhirnya vakum karena beberapa hal.Setelah vakum, alat musik Gambang Kromong tersebut dikembalikan ke tempat ketua RW, dan anak-anak muda di lingkungan tersebut sempat memakai untuk latihan secara autodidak (wawancara dengan bang Sahroni, Rabu 23 Maret 2016).

\subsubsection{Tahun 2001}

Perkampungan Budaya Betawi diresmikan di Setu Babakan Srengseng Sawah sesuai dengan Surat Keputusan Gubernur nomor 92 tahun 2000.Muncul program Pemda DKI Jakarta melalui Dinas Kebudayaan untuk melakukan 
pembinaan kesenian tradisi Betawi, yaitu: musik (Gambang Kromong), tari, dan teater (Lenong). Usaha melestarikan budaya tradisi tercuat dari pemerintah DKI Jakarta yang mulai menyadari bahwa kondisi budaya tradisi di daerahnya ada dalam fase kritis.Tujuan dari program tersebut adalah merekrut masyarakat (terutama masyarakat sekitar Perkampungan Budaya Betawi Setu Babakan) untuk berlatih dan mempelajari kesenian Betawi. Pemda DKI mendatangkan pelatih dari dinas untuk mengajar kesenian-kesenian Betawi disana. Program pembinaan kesenian tersebut dianggarkan oleh pemerintah untuk 2 tahun lamanya program. Pemdamendatangkan pelatih yang diantaranya adalah Pak Diman dan Bang Maman sebagai pelatih musik (Gambang Kromong), bang Andi, bang Joko SS, dan ibu Kartini sebagai pelatih tari, pak Diding dan pak Syaiful Amri sebagai pelatih teater (wawancara dengan bang Sahroni, Rabu 23 Maret 2016).

\subsubsection{Tahun 2002}

Program pembinaan kesenian dari pemerintah berjalan dengan baik.Tampak semangat para remaja yang tertarik mengikuti program tersebut.Masyarakat sekitar Perkampungan Budaya Betawiyang ingin pelatihan kesenian-kesenian Betawi terus berjalan akhirnya secara swadaya masyarakat berinisiatif melakukan revolusi dengan mendirikan sebuah sanggar seni yang diberi nama Sanggar Seni Betawi Setu Babakan. Hal tersebut disampaikan oleh bang Sahroni sebagai berikut:

Program pemerintah itukan tergantung dana, kalau dananya ada setahun ya setahun, kalau dua tahun ya dua tahun, setelah itukan akan hilang begitu saja. Nah, animo dari anak-anak remaja yang sudah besar yang sudah antusias mempelajari kesenian akhirnya akan terputus, di sekitar 
sini sudah tidak ada wadah atau tempat untuk mereka latihan, tidak ada sanggar. Akhirnya kita bentuk, kita bikin aja udah, kita bikin sanggar. Atas kesepakatan, kita bikin namanya apa nih? Adanya Setu Babakan, yaudah kita namain "Sanggar Seni Betawi Setu Babakan”, disitu ada tari, ada Lenong, ada Gambang Kromong.

Dari pernyataan tersebut nampak bahwa kesadaran kelompok-kelompok masyarakat Jakartaakan kebudayaan tradisi yang kian tersingkir, sebenarnya sudah berusaha diwujudkan melalui usahaseperti salah satunya membuat wadahwadah kesenian.Sanggar Seni Betawi Setu Babakan kemudian dijalankan dengan swadaya masyarakat dan iuran rutin peserta sanggar tiap bulannya.Kepengurusan sanggar pada awal dibentuk dipimpin oleh bapak Romi Rojali.Kegiatan latihan rutin untuk Gambang Kromong pada waktu itu dilangsungkan dua kali dalam seminggu, yaitu pada Selasa malam dan Jumat malam, dengan pelatih yang sama seperti yang diberikan oleh dinas, yaitu pak Diman dan bang Maman (wawancara dengan bang Sahroni, Rabu 23 Maret 2016).

\subsubsection{Tahun $2002-2007$}

Hasil dari sanggar ini terus terlihat dan berkembang dengan cukup baik.Anggota sanggar terus bertambah, minat masyarakat sekitar wilayah Perkampungan Budaya Betawi Setu Babakan seperti daerah Pasar Minggu, daerah Depok, daerah Lenteng Agung, dan sekitarnya, terus meningkat. Prestasi anak didik dari sanggar ini juga terus meningkat, tidak sedikit anak didiknya yang mengikuti lomba-lomba kesenian tradisi baik tingkat Kotamadya, Provinsi, maupun nasional.Secara berturut-turut, yaitu pada tahun 2003, 2004, dan 2005, Sanggar Seni Betawi Setu Babakan memegang jabatan sebagai duta seni pelajar se-Jawa Bali.Tentunya adalah suatu kehormatan besar dan langka, tatkala 
Gambang Kromong dari sanggar seni Betawi Setu Babakan ini diberi kesempatan untuk menjadi duta seni pelajar se-Jawa Bali selama 3 tahun.Pada tahun 2006, pencapaian yang baik kembali diraih oleh Gambang Kromong dari Sanggar ini. Diantara sekian banyak sanggar kesenian Betawi dan banyak kelompok Gambang Kromong di Jakarta, Gambang Kromong dari Setu Babakan dipilih untuk mewakili Provinsi DKI Jakarta dalam acara musik tradisi nusantara yang diadakan di Taman Mini Indonesia Indah (TMII) (wawancara dengan bang Sahroni, Rabu 23 Maret 2016).

\subsubsection{Tahun 2007 - Sekarang}

Tahun 2007 adalah saat dimana regenerasi kepengurusan sanggar Seni Betawi Setu Babakan. Kepemimpinan pak Romi Rojali digantikan oleh bang Sahroni. Bang Sahroni menduduki posisi sebagai pimpinan sanggar hingga saat penelitian ini dilakukan. Demikian pula dengan kesenian Gambang Kromong yang ada di sanggar ini juga terus beregenerasi.Setelah terjadi regenerasi kepengurusan sanggar tersebut, pelatih Gambang Kromong mulai tahun 2008 dipegang oleh bang Andi sampai hari ini. Bang Andi adalah seorang keturuan seniman Topeng Betawi yang kemudian terjun ke dunia musik Gambang Kromong. Bang Andi mempunyai sebuah sanggar seni Topeng Betawi warisan kakek dan neneknya yang bertempat di rumahnya, tepatnya di daerah Cisalak dengan nama "Kinang Putera”. Sanggar Topeng Betawi milik bang Andi tersebut sedang tidak aktif melakukan latihan rutin karena bang Andi fokus menjadi pelatih musik dan tari di Sanggar Seni Betawi Setu Babakan. Awalnya, bang Andi memegang tugas utama sebagai pelatih tari di Perkampungan Budaya Betawi 
sejak tahun 2002, namun mulai tahun 2008 beliau menjadi pelatih tari sekaligus musik menggantikan pak Diman dan bang Maman.

Saat ini para pemain Gambang Kromong sudah sampaipada generasi yang ke-4, dimana generasi ke-4 ini beranggotakan anak-anak usia SD sampai SMP. Generasi ke-3 masih tetap eksis keberadaannya, bahkan generasi ke-3 ini adalah yang sedang aktif-aktifnya mengikuti banyak event kebudayaan.Untuk generasi ke-2 Gambang Kromong dari sanggar seni Betawi Setu Babakan, kini sudah mulai habis, tersisa bang Erik yang kini bergabung dan membantu membimbing angkatan di bawahnya.Hilangnya para pemain Gambang Kromong dari generasi terdahulu terjadi karena banyak faktor, salah satunya karena pemain Gambang Kromong terdahulu banyak didominasi kaum wanita.Selepas wanita tersebut menikah, maka menurut pengalaman yang sudah-sudah, para pemain tersebut akan berhenti bermain Gambang Kromong (wawancara dengan bang Sahroni, Rabu 23 Maret 2016). Tanggung jawab wanita sebagai isteri dan ibu rumah tangga membuat kondisi untuk terus berkesenian menjadi sulit bahkan tidak memungkinkan.

Latihan musik Gambang Kromong saat ini secara rutin berlangsung setiap hari Jumat malam sekitar pukul 19.30 hingga selesai untuk kelompok pemain dari generasi ke-3.Para pemain Gambang Kromong generasi ke-4 yang mana usianya masih terbilang anak-anak, berlatih rutin setiap hari Minggu pukul 08.3010.00.Latihan di luar jadwal rutin tersebut juga kerap dilakukan, terutama saat akan mengikuti suatu event. Lokasi latihan tersebut dilakukan di panggung teater terbuka Perkampungan Budaya Betawi. Seluruh kebutuhan alat musik dan sound 
system untuk latihan sudah tersedia di Perkampungan Budaya Betawi, namun untuk alat musik gesek tehyan, kongahyan, dan sukong, biasanya para pemain membawa alatnya masing-masing.Pada tahun 2013 lalu, sanggar ini mendapat bantuan dari Kementrian Pendidikan dan Kebudayaan setelah mengajukan proposal peremajaan alat.Bantuan tersebut diperoleh berupa dana yang kemudian dipakai untuk pembelanjaan instrumen-instrumen baru (wawancara dengan bang Sahroni, Rabu 23 Maret 2016).

Sanggar seni Betawi Setu Babakan, termasuk Gambang Kromong di dalamnya, menjadi semakin hidup karena sanggar mereka berada di wilayah Perkampungan Budaya Betawi. Kunjungan-kunjungan yang sering diterima oleh pihak Perkampungan Budaya Betawi, secara otomatis akan turut melibatkan sanggar seni tersebut dalam menyajikan tampilan kesenian tradisi Betawi bagi para tamunya berupa tari dan Gambang Kromong.Tamu-tamu tersebut banyak datang dari pihak sekolah yang membawa peserta didiknya untuk mengenal budaya Betawi, banyak pula tamu dari badan Pemerintahan yang berkunjung ke Perkampungan Budaya Betawi.

Perkembangan sanggar seni Betawi Setu Babakan terus berjalan cukup signifikan.Tahun 2013, prestasi dari anak didik sanggar ini terus nampak dan berkembangmelangkahkan jejaknya di dunia internasional. Salah satu pemain Gambang Kromong dari sanggar ini, yaitu Rendy (pemain gendang) berangkat ke Jepang bersama bang Andi pelatihnya untuk acara festival budaya yang diikuti seluruh negara pada tahun 2013 lalu.Setelah acara tersebut, Rendy kembali berangkat ke Eropa Tengah untuk mengkolaborasikan kesenian Betawi dengan 
permainan angklung (Jawa Barat) dalam acara festival dari Kementrian Pendidikan dan Kebudayaan di Praha Ibukota Ceko.

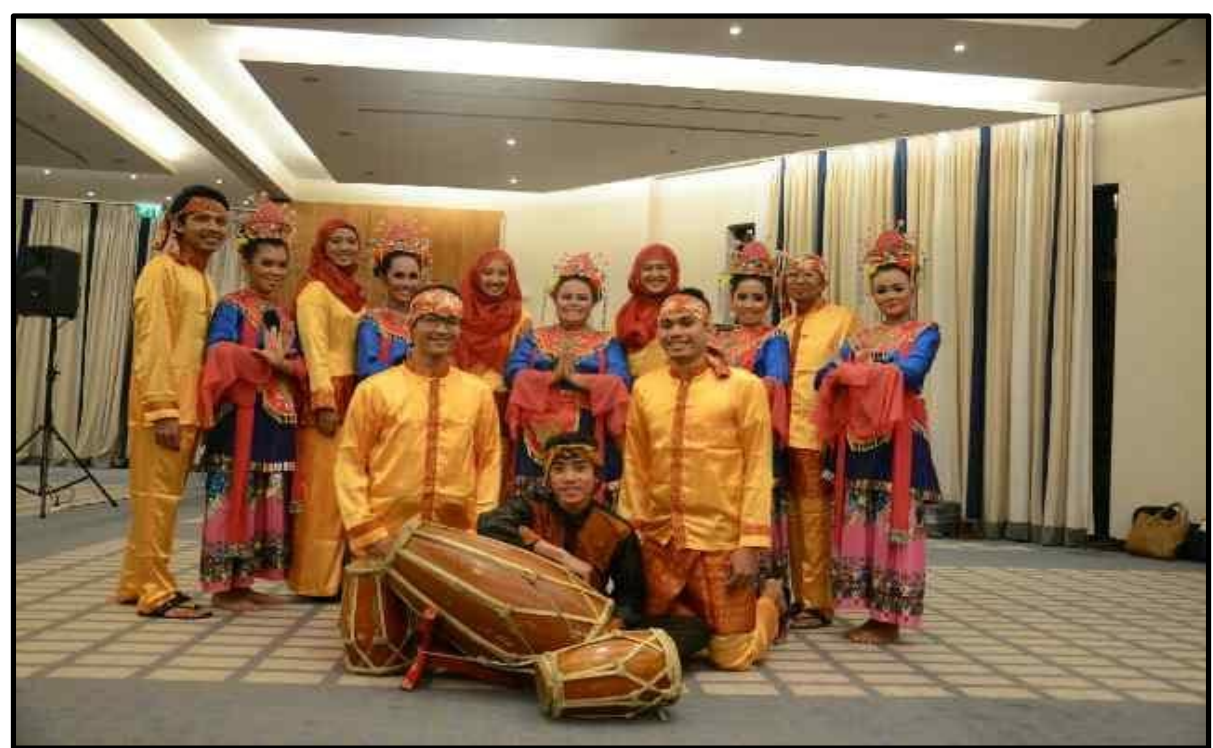

Gambar 4.2.5.1. Rendy (Pemain Gendang) Bersama Tim Kolaborasi Kesenian Betawi dan Jawa Barat di Gedung Kedutaan Besar Republik Indonesia di Praha (Foto:Rendy, 2013)

\subsection{Enkulturasi Musik Gambang Kromong di Perkampungan Budaya Betawi Setu Babakan}

Proses enkulturasi terjadi dimana orang-orang muda belajar dan mengadopsi hal-hal yang hidup dan berkembang dalam budaya mereka. Enkulturasi umumnya menunjuk pada produk dari proses sosialisasi. Sosialisasi umumnya menunjuk lebih pada proses dan mekanisme nyata dimana orang mempelajari aturan-aturan sosial dan budaya, yang ditujukan kepada siapapun, dan dalam konteks tertentu, sedangkan enkulturasi merujuk pada pemeliharan berupa penghayatan aspek-aspek dari budaya asalnya. Setelah melakukan 
kegiatan observasi dan wawancara, ditemukan fakta lapangan bahwa proses enkulturasi Gambang Kromong di Perkampungan Budaya Betawi Setu Babakan terjadi melalui jalur informal (keluarga dan lingkungan masyarakat) dan sebagian besar melalui jalur nonformal (sanggar).

\subsubsection{Enkulturasi Musik Gambang Kromong di Perkampungan Budaya Betawi Melalui Jalur Informal (Keluarga dan Lingkungan Masyarakat)}

Proses enkulturasi Gambang Kromong di Perkampungan Budaya Betawi melalui jalur informal terjadi di dalam beberapa keluarga. Proses tersebut berlangsung dengan sendirinya tanpa disengaja. Melalui jalur ini, orang tua, seolah tanpa disadari, telah membawa anaknya mempelajari Gambang Kromong dengan metode pelaziman.Orang tua yang adalah panjak (dalam bahasa betawi artinya pemain musik), sering memutar lagu-lagu Gambang Kromong di rumah, atau membawa anaknya ke lokasi latihan. Melalui hal tersebut, anak dari panjak menjadi terbiasa akrab dengan musik Gambang Kromong, caraini membawa anak untuk mendengar, mengenal, menyenangi, dan lama kelamaan mencoba bermain musik Gambang Kromong. Metode pelaziman yang terjadi secara tidak disengaja tersebut terjadi bahkan sejak usia anak-anaknya masih balita.Orang tua yang mengajak anaknya ke lokasi latihan membuat anak tersebut terbiasa melihat dan mendengar, bahkan bermain-main dengan instrumen-instrumen Gambang Kromong. 
Contoh kegiatan enkulturasi melalui proses pelaziman dari orang tua kepada anaknya, terjadi dalam keluarga bang Erik. Bang Erik adalah masyarakat yang tinggal di wilayah Perkampungan Budaya Betawi, beliau awalnya adalah seorang asisten pengajar tari di sanggar Seni Betawi Setu Babakan, namun kemudian beranjak menjadi pemain Gambang Kromong. Bang Erik saat ini sering memegang instrumen tehyan, sedangkan isteri dari bang Erik adalah mpok Apriarni yang juga merupakan seorang vokalis Gambang Kromong sekaligus penari Betawi. Bang Erik dan mpok Apriani membawa anaknya, Banu Naufal setiap kali mereka latihan rutin yaitu hari Jumat malam. Usia Banu, anak mereka, baru 1 tahun 6 bulan, namun bagi mereka memperkenalkan musik Gambang Kromong kepada anaknya ini memang "pas” jika dimulai sejak dini. Saat latihan berlangsung, Banu sering bermain-main dengan instrumen-instrumen Gambang Kromong, dan para panjak yang lain tidak merasa terganggu dengan kehadiran Banu, bahkan mereka senang karena Banu tampak menyukai musik ini. Proses pelaziman dalam keluarga bang Erik juga berlangsung saat di rumah, beliau tanpa sengaja membuat anaknya terbiasa mendengar lagu-lagu Gambang Kromong. Berikut perkataan bang Erik saat diberikan pertanyaan seputar bagaimana beliau membawa anaknya menyukai Gambang Kromong:

Awalnya saya gak ada niat khusus ngajak Banu dateng latihan, begitupula kalau di rumah dia suka denger lagu-lagu Gambang Kromong itu gak sengaja. Saya mah sering muter lagu-lagu Gambang Kromong di rumah karena saya seneng, gak sengajakan dia jadi ikut dengerin juga tuh. Sekarang dia itu kalau nangis rewel mau tidur, diputerin aja lagu Gambang Kromong, langsung anteng udah dia tidur sendiri.Ya mudah-mudahan aja besok bisangewarisin kesenian ini ke dia, biar ada regenerasi, biar gak punah, kalau bukan kita yang melestarikan kesenian kita, siapa lagi sih. 
Melalui pernyataan bang Erik dalam wawancara tersebut, tampak bahwa pewarisan kesenian Gambang Kromong oleh bang Erik dan mpok Apriani, terjadi tanpa disengaja, bang Erik dan isterinya tidak merasa dirinya sebagai pendidik, dan Banu anaknya, tidak merasa sebagai peserta didik. Hal tersebut sejalan dengan pernyataan Triyanto (2015:51) tentang enkulturasi dalam keluarga yang mengatakan bahwa:

Semuanya itu (proses pewarisan budaya dalam keluarga) berlangsung secara alamiah, seolah tanpa direncana atau disengaja.Dalam kondisi seperti inilah suatu warisan budaya atau seni dienkulturasikan antargenerasi.Proses-proses tersebut berlangsung secara terintegrasi dalam kegiatan rutin keseharian.

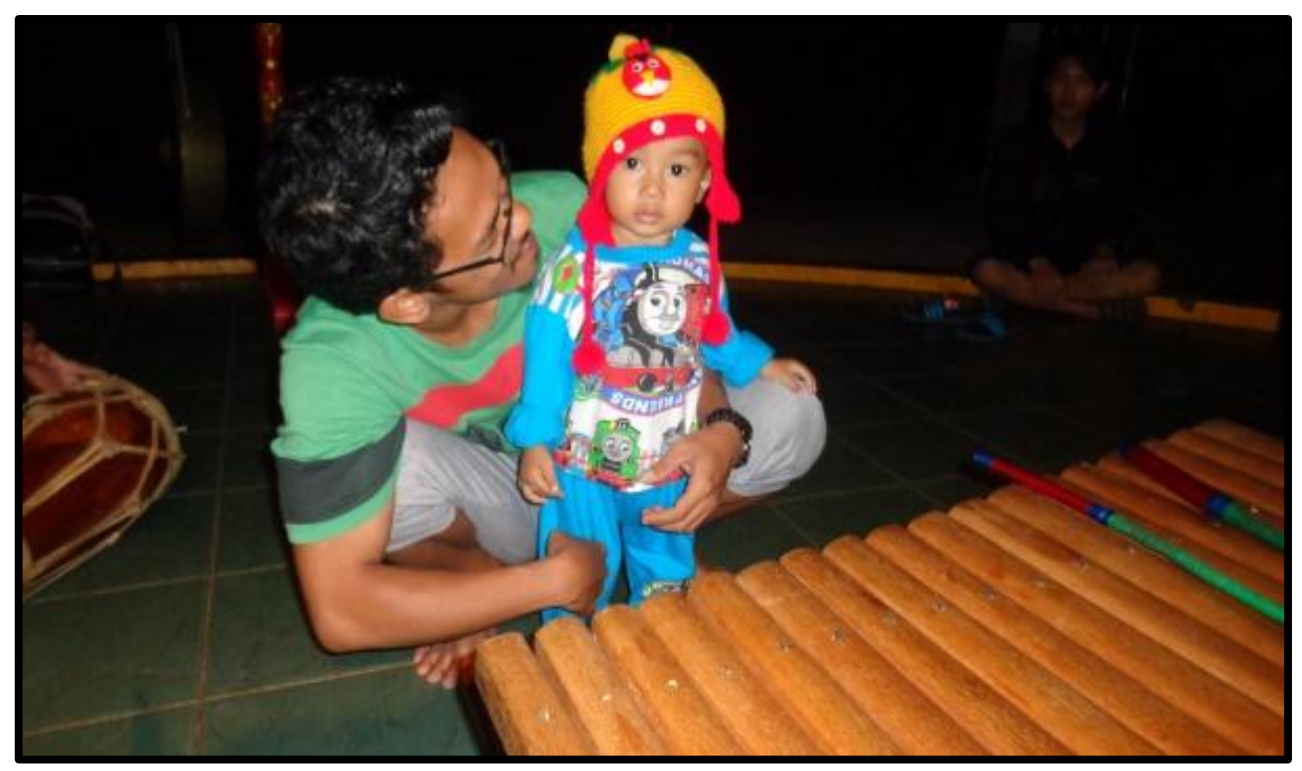

Gambar 4.3.1.1.Bang Erik yang Kerap Membawa Banu Anaknya Saat Latihan Musik Gambang Kromong (Foto: Marissa RH, 6 Januari 2016) 


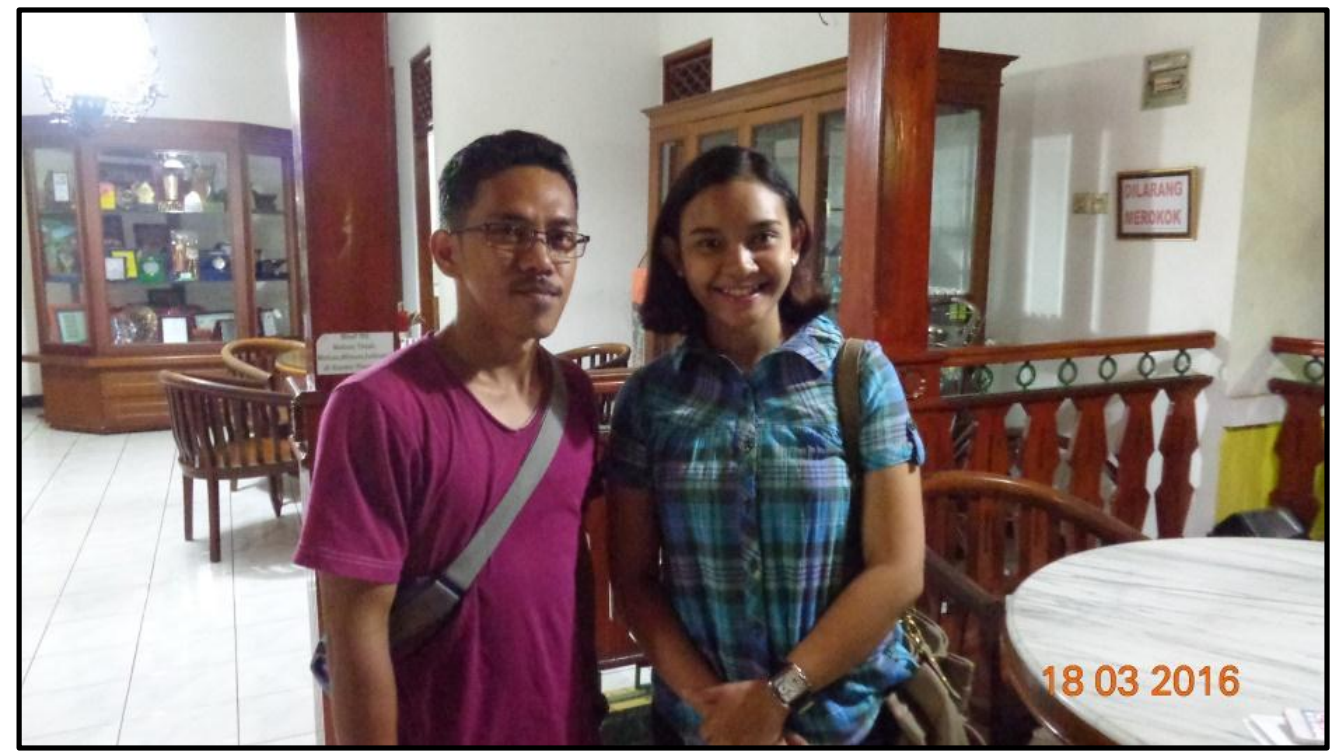

Gambar 4.3.1.2.Penulis dengan Bang Erik

(Foto: Marissa RH, 18 Maret 2016)

Selain dalam keluarga bang Erik, proses enkulturasi Gambang Kromong dalam keluarga juga terjadi pada keluarga bang Andi (pelatih musik dan tari). Dalam keluarga bang Andi, beliau tanpa sengaja mewariskan kesenian ini kepada dua anak perempuannya, Suci dan Nia. Bang Andi yang juga biasa mengadakan latihan Gambang Kromong di sanggar miliknya di rumahnya, membuat dua anaknya tersebut menjadi tertarik dengan musik ini dan ikut bermain saat latihan berlangsung. Hal tersebut membuat kedua anak bang Andi, Suci dan Nia, menjadi panjak seperti beliau. Suci adalah seorang vokalis Gambang Kromong, dan Nia seorang pemain tehyan, kini mereka sering ikut bermain pada saat grup tersebut mendapat kesempatan tampil.

Proses enkulturasi Gambang Kromong melalui lingkungan sosial masyarakat terjadi dalam keluarga bang Sahroni yang adalah ketua sanggar 
Betawi Setu Babakan. Berawal dari kegiatan rutin beliau yang wajib memantau berlangsungnya latihan-latihan kesenian, bang Roni sering mengajak Rani, anak perempuannya, untuk ikut memantau latihan.Rani yang ikut ayahnya memantau latihan Gambang Kromong, menjadi sering mendengarkan musik tersebut, dan melihat teman-teman sebayanya latihan. Teman-teman sebaya Rani kemudian mengajaknya untuk ikut bermain musik Gambang Kromong, hal tersebut membuat Rani menjadi semakin tertarik dan menyukai musik ini karena ia bisa bermain musik bersama teman-teman sebayanya, hingga akhirnya Rani ikut menjadi panjak sejak SD, awalnya ia memainkan instrumen kecrek, namun mulai kelas 4 SD ia menjadi pemain instrumen kromong (wawancara dengan bang Sahroni, Rabu 23 Maret 2016). 


\subsubsection{Enkulturasi Musik Gambang Kromong di Perkampungan Budaya \\ Betawi Setu Babakan Melalui Jalur Nonformal (Sanggar)}

Sebagai lingkungan yang dipilih Pemerintah Provinsi DKI Jakarta sebagai lokasi pelestarian budaya, Perkampungan Budaya Betawi Setu Babakan ibarat angin segar ditengah kesesakan era globalisasi wilayah Jakarta dan sekitarnya yang kian menggusur kebudayaan tradisi masyarakatnya.Ditambah dengan kehadiran sanggar seni yang dibangun oleh masyarakat yang tinggal di Perkampungan Budaya Betawi, semakin membuat pemerintah dan masyarakat Betawi bisa sedikit bernapas lega.Usaha-usaha pewarisan kebudayaan Betawi di tempat ini terus ditunjukan sebagian besar penduduknya, dikatakan sebagian besar karena ditemukan juga warga masyarakat yang cuek padahal mereka sadar mereka tinggal di wilayah pelestarian budaya.Sanggar Seni Betawi Setu Babakan dalam hal ini bisa kita pahami sebagai sebuah organisasi masyarakat dalam bidang kesenian yang berada di wilayah Perkampungan Budaya Betawi.Organisasi sendiri menurut Liliweri (1997:160) adalah sebuah wadah, wahana, dan media perkumpulan sejumlah orang yang telah menetapkan keinginan dan kehendaknya untuk bekerja sama mencapai tujuan. Secara sosiologi, organisasi merupakan satuan sosial atau komunitas khusus yang merupakan gabungan dan ikatan pribadi-pribadi yang mempunyai nilai dan norma yang sama. Sedangkan menurut tinjauan psikologi, kelompok tersebut terbentuk karena ikatan psikologis, dan dalam ranah psikologis sosial, kelompok diasumsikan sebagai wadah manifestasi peranan dan kedudukan pribadi dalam kelompok sosial. 
Semangat masyarakat Perkampungan Budaya Betawi dan sekitarnya dalam hal bersatu untuk semakin mengenal, mempelajari, mencintai, dan mewariskan budaya Betawi dalam bidang kesenian melalui Sanggar Seni Betawi Setu Babakan, tampak pada jumlah peserta sanggar yang saat ini secara keseluruhan mencapai sekitar seribu orang. Dalam hal ini terjadi proses enkulturasi yang dilakukan secara sadar dan terkelola. Proses enkulturasi tersebut terus berjalan sejak awal diresmikannya perkampungan budaya ini oleh pemerintah DKI Jakarta.Atoshoki dalam jurnal Humaniora Bina Nusantara University (2011:141) menyatakan bahwa:

dalam proses enkulturasi terdapat agen yang selalu hadir untuk memastikan bahwa enkulturasi terus terjadi, mereka adalah orang, lembaga dan organisasi-organisasi sosial. Agen pertama dan terpenting adalah orang tua. Mereka berperan menanamkan moral dan nilai-nilai budaya kepada anak-anak mereka, meneguhkan moral dan nilai-nilai tersebut ketika mereka belajar dan mempraktekkannya dengan baik seraya terus memperbaiki kesalahan dalam proses belajar tersebut.

Dalam pernyataan tersebut diterangkan bahwa, orang tua adalah agen pertama dan terpenting, dari dan di dalam keluarga, anak sebagai generasi penerus dibentuk sejak dini oleh orang tua dan lingkungannya.Namun pun demikian, orang tua bukanlah satu-satunya agen dari enkulturasi. Saudara, keluarga besar, teman-teman, dan sahabat adalah termasuk agen-agen penting bagi banyak orang untuk proses enkulturasi. Organisasi seperti sekolah, lembaga keagamaan, dan kelompok-kelompok sosial lainnya juga menjadi agen-agen penting dari proses ini. Kenyataannya, ketika kita belajar lebih banyak tentang proses enkulturasi, 
akan menjadi kelihatan bahwa budaya dilaksanakan dan dikuatkan oleh banyak orang dan institusi (Atoshoki, 2011:141).

Dalam konteks pewarisan kesenian Gambang Kromong secara nonformal di Perkampungan Budaya Betawi Setu Babakan, proses penyampaian dan pewarisan berkesenian dari pendidik (pelatih sanggar), dan penerimaan oleh subjek didik (peserta sanggar) berlangsung melalui kegiatan latihan rutin yang diadakan sanggar.Latihan Gambang Kromong tersebut berlangsung dua kali dalam seminggu secara rutin, dimana hari Jumat malam adalah waktu kelompok generasi ke-3 latihan, dan minggu pagi adalah waktu latihan untuk kelompok generasi ke-4 (anak-anak).Selain dari jadwal tersebut, latihan-latihan tambahan sering diadakan, terutama saat mendapat kesempatan tampil dalam acaraacara.Berdasarkan hasil pengamatan selama penelitian ini berlangsung, proses pembelajaran Gambang Kromong disampaikan oleh pelatih melalui model pemberian contoh. Masing-masing subjek didik dengan masing-masing instrumennya, diberikan contoh cara permainan musik Gambang Kromong oleh pelatihnya, kemudian anak tersebut akan memperhatikan, dan kemudian meniru apa yang telah dicontohkan pelatihnya.

Melalui model pemberian contoh tersebut, pelatih atau guru mengajarkan atau menyampaikan segala sesuatu yang berkenaan dengan konteks Gambang Kromong dalam kondisi latihan yang santai namun tetap serius disetiap waktu latihan.Para pemain atau subjek didik menerima yang diberikan pelatihnya melalui praktik langsung bermain musik bersama teman-teman kelompoknya.Apabila terjadi kesalahan-kesalahan permainan atau kekurang 
pahaman, subjek didik tidak segan untuk bertanya kepada pelatihnya karena kondisi akrab yang sudah tercipta antara pelatih dan peserta didik sanggar. Begitupun sebaliknya, bang Andi mengajar anak-anak sanggar dengan memandang mereka seperti anaknya sendiri, sehingga tidak jarang pula saat subjek didik banyak melakukan kesalahan padahal sudah dicontohkan berkalikali, atau bahan tersebut sudah berminggu-minggu dibahas, bang Andi menegur anak didiknya. Teguran bang Andi tidak serta merta hingga menyakiti hati anak didiknya, beliau menegur dan menasehatisepantasnya, hanya sebatas teguran ringan untuk mengembalikan fokus dan semangat belajar anak didiknya. Setelah menegur, bang Andi akan menghampiri anak didiknya yang belum paham tersebut untuk kembali memberi contoh pada bagian yang anak tersebut kurang pahami.

Ada beberapa tahapan mengenai proses pewarisan seni musik tradisi Betawi Gambang Kromong, yakni proses perkenalan, proses melihat (pemberian contoh), meniru, serta proses pembinaan (latihan). Hal tersebut telah menjadi tradisi Sanggar Seni Betawi Setu Babakan dalam mewariskan musik Gambang Kromong dan beberapa jenis kesenian lainnyaseperti tari, beksi, dan lenong, sebagai upaya pelestarian kesenian Betawi. 


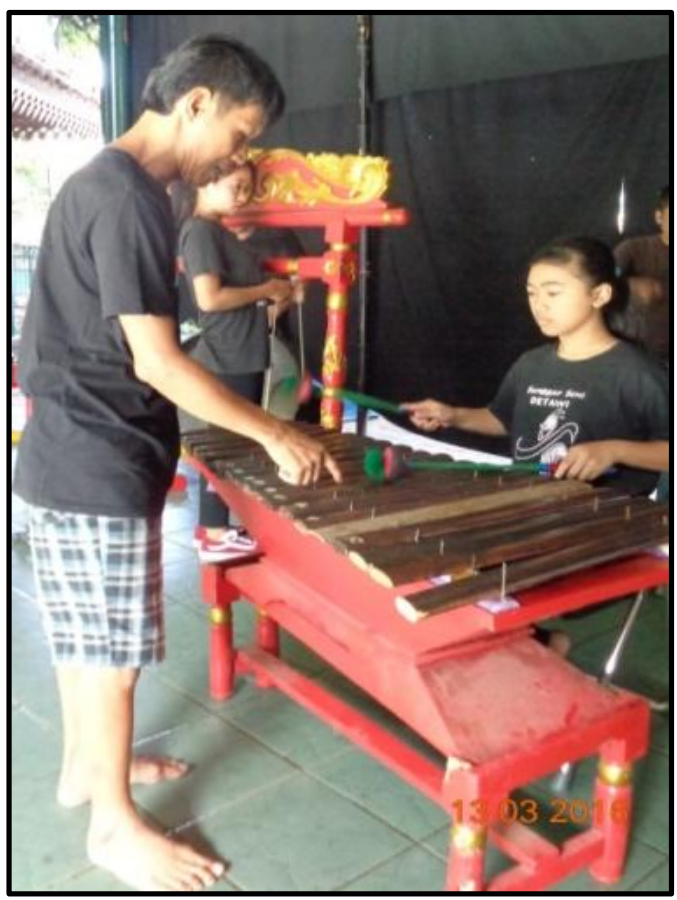

Gambar 4.3.2.1. Proses Pemberian Contoh oleh Bang Andi (Pendidik) kepada Peserta Sanggar Pemain Gambang (Peserta Didik)

(Foto: Marissa RH, 13 Maret 2016)

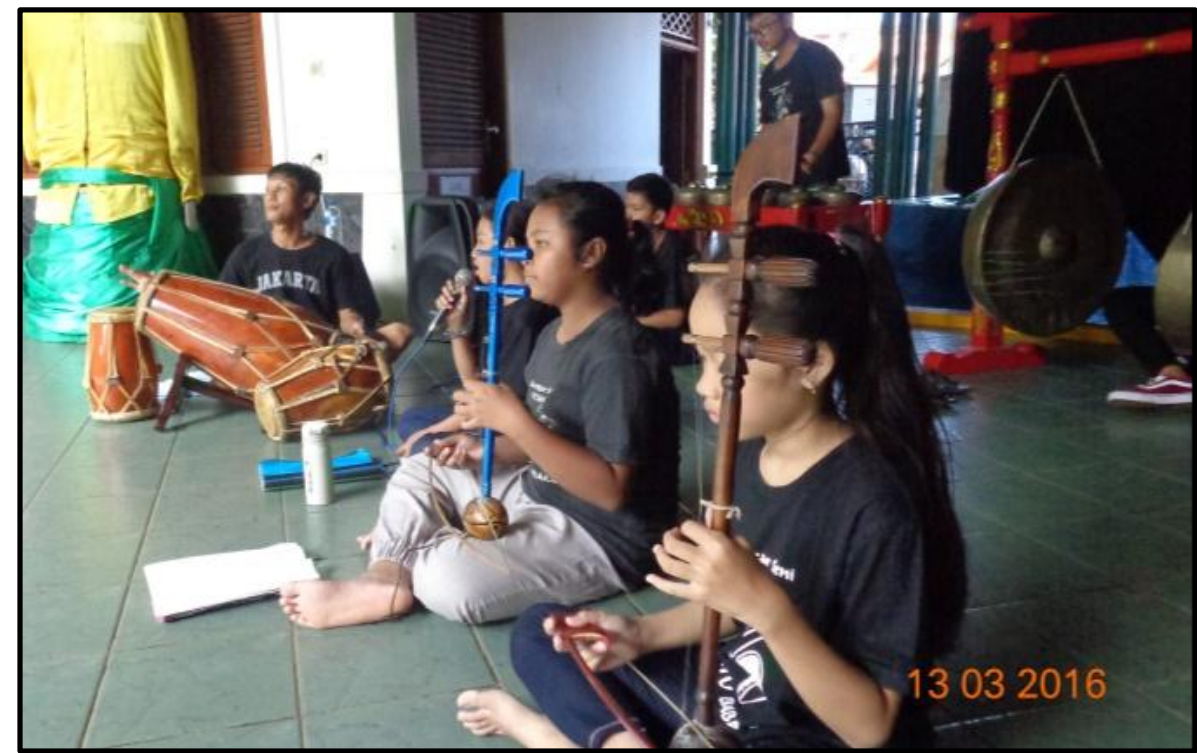

Gambar 4.3.2.2. Setelah Melihat Contoh yang Diberikan Pelatihnya, Anak-anak Mempraktikan Bermain Lagu-lagu Gambang Kromong Bersama Teman Sekelompoknya

(Foto: Marissa RH, 13 Maret 2016) 


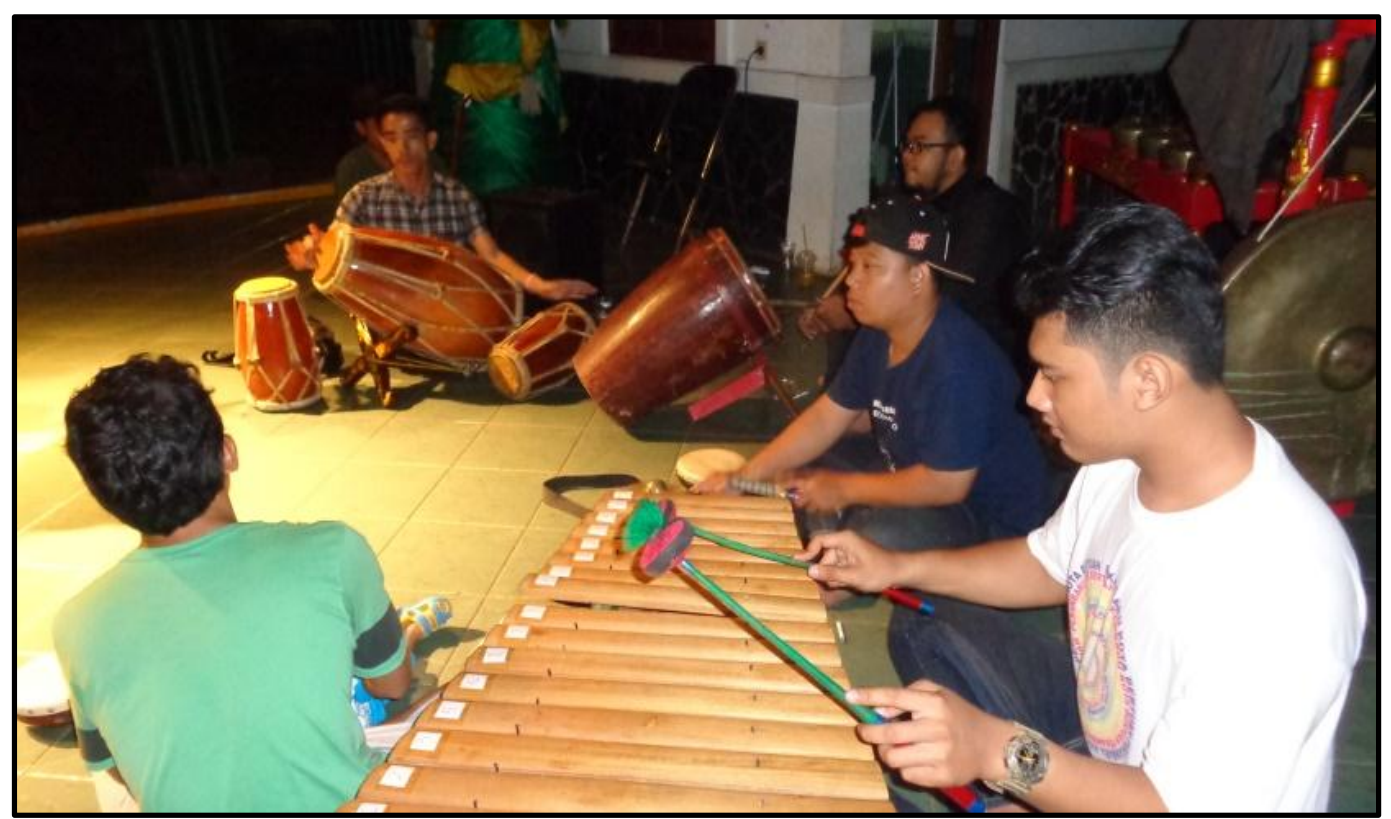

Gambar 4.3.2.3.Proses Latihan/Pembinaan Generasi Ke-3 Gambang Kromong dari Sanggar Seni Betawi Setu Babakan

(Foto: Marissa RH, 6 Januari 2016)

Peran dukungan orang tua dalam usaha pewarisan kesenian tradisi Betawi ini juga tampak dalam kegiatan latihan rutin sanggar.Orang tua memberi dukungan bagi anak-anaknya dengan mengantar mereka sampai di lokasi latihan, bahkan mendampingi hingga latihan selesai. Orang tua dari anak didik sanggar ini ada pula yang merupakan seniman Betawi (pemain musik tradisi Betawi, atau penari Betawi), mereka mengikut sertakan anaknya dalam sanggar dengan harapan bahwa anaknya akan mempelajari kesenian Betawi dengan lebih terprogram dan teratur, melalui sanggar ini pula orang tua berharap anaknya tidak hanya bisa berkesenian tetapi juga memiliki sosial dan kepercayaan diri yang baik. Memang ditemukan kenyataanbahwa ada orang tua yang menaruh harapan untuk anaknya mampu memiliki sosial dan kepercayaan diri yang baik dengan 
cara memasukannya ke pelatihan kesenian. Karena dalam kegiatan sanggar, anak akan berinteraksi secara langsung dengan banyak teman sebayanya, bahkan dengan teman yang lebih tua atau lebih muda dari dirinya. Selain itu, kegiatan sanggar yang rutin mengadakan pentas yang ditonton oleh banyak orang juga memberikan latihan kepercayaan diri bagi anak didiknya.

Ketika mendampingi anaknya latihan, para orang tua tampak saling berbincang akrab, selain itu orang tua yang juga adalah seniman Betawi, acap kali membantu semampu mereka saat latihan Gambang Kromong karena melihat bang Andi yang harus mengajar banyak anak dengan berbagai instrumennya.Melalui hal ini pula, tampak sifat kekeluargaan yang baik telah terjalin antara pelatih dengan peserta didik, peserta didik dengan sesama peserta didik, orang tua dengan sesama orang tua peserta didik, dan pelatih dengan orang tua, yang berusaha saling mendukung dengan tujuan yang sama yaitumewariskankesenian tradisi Betawi kepada anak-anak mereka. 


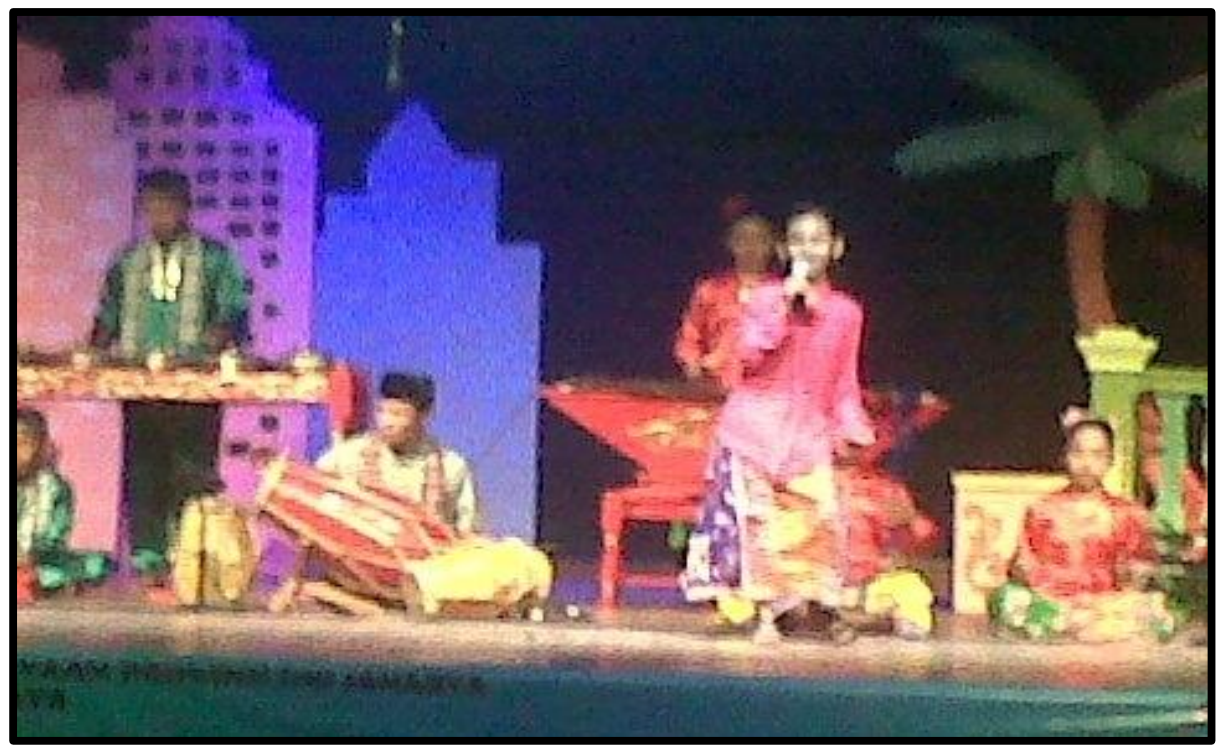

Gambar 4.3.2.4.Kesempatan Pentas Merupakan Ajang Melatih Kepercayaan Diri Anak. Pada Foto Adalah Peserta Didik Sanggar yang Merupakan Generasi Ke-4

Gambang Kromong Setu Babakan, Saat Tampil dalam Salah Satu Acara di Gedung Balai Latihan Seni Tanah Abang (Sumber: Orang Tua dari Rizka Vokalis Gambang Kromong)

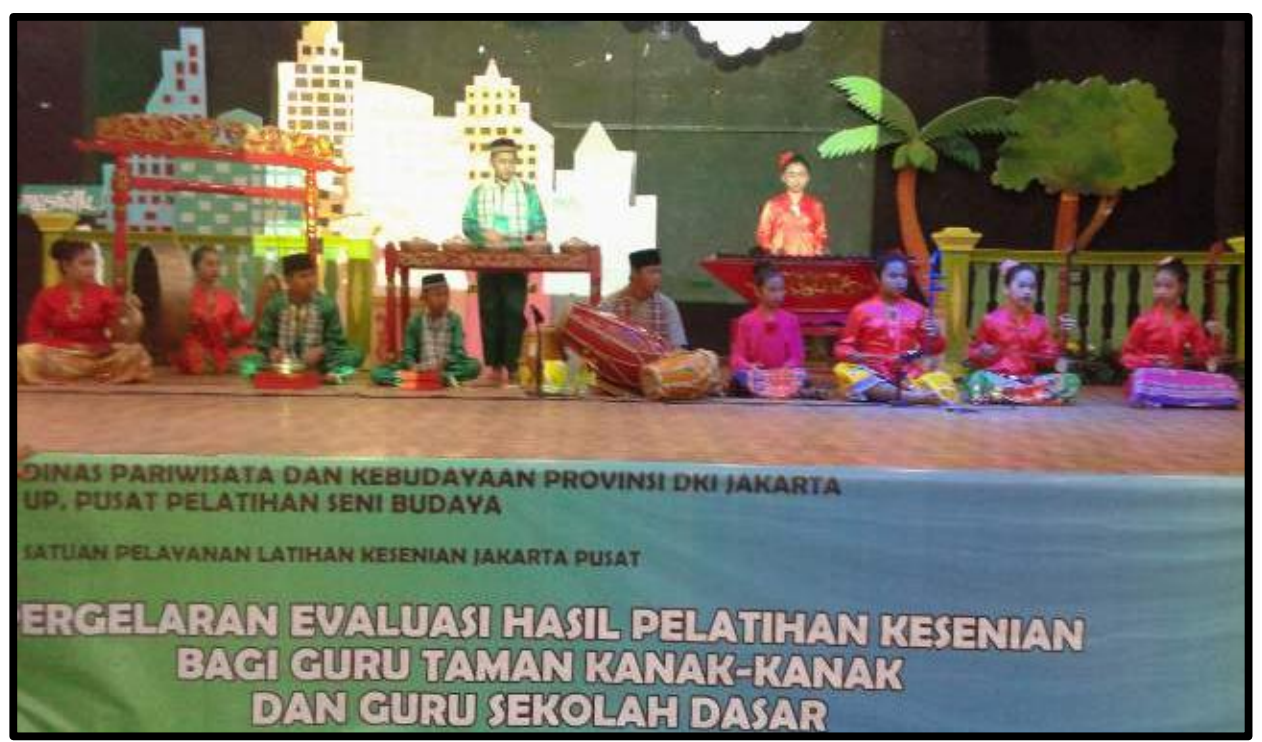

Gambar 4.3.2.5. Pentas Peserta Didik Sanggar yang Merupakan Generasi Ke-4 Gambang Kromong Setu Babakan, Saat Mengisi Acara Pergelaran Evaluasi Hasil Pelatihan Kesenian (Sumber: Orang Tua dari Fadhil Pemain Kromong) 


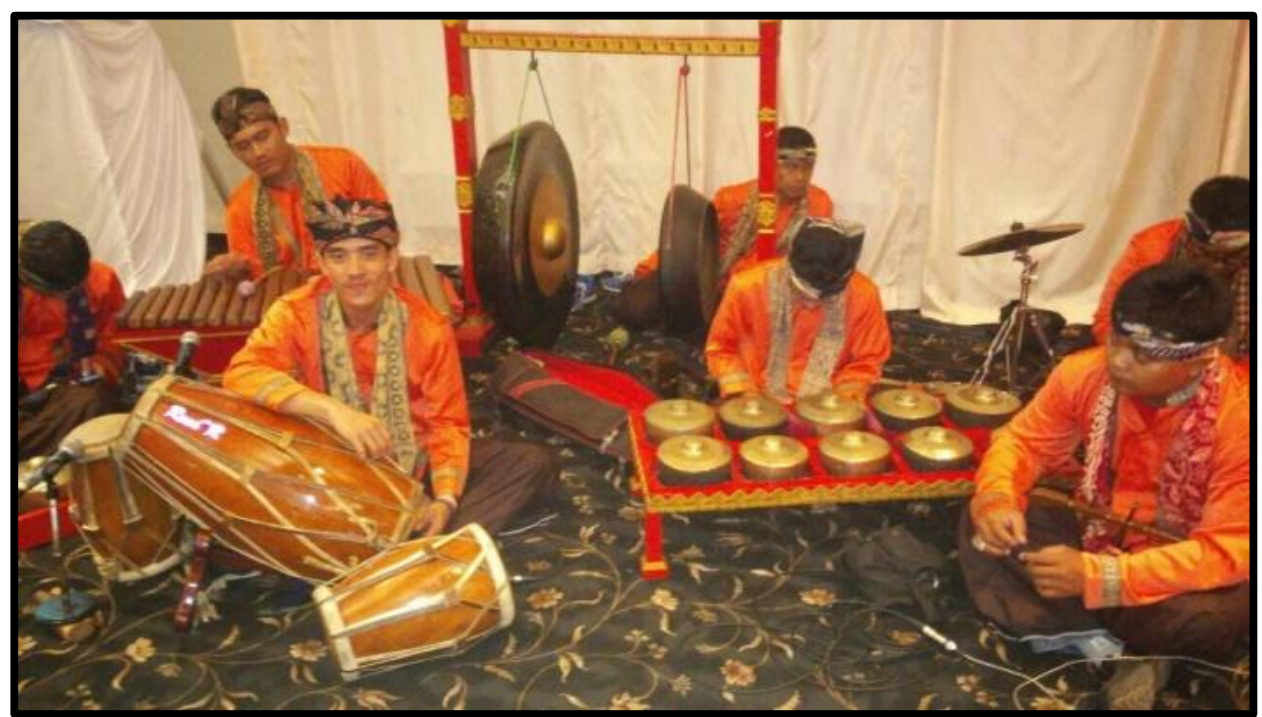

Gambar 4.3.2.6. Pentas Peserta Didik Sanggar yang Merupakan Generasi Ke-3 Gambang Kromong Setu Babakan, Saat Mengisi Acara di Hotel Mercure Ancol (Sumber: Rendy Pemain Gendang)

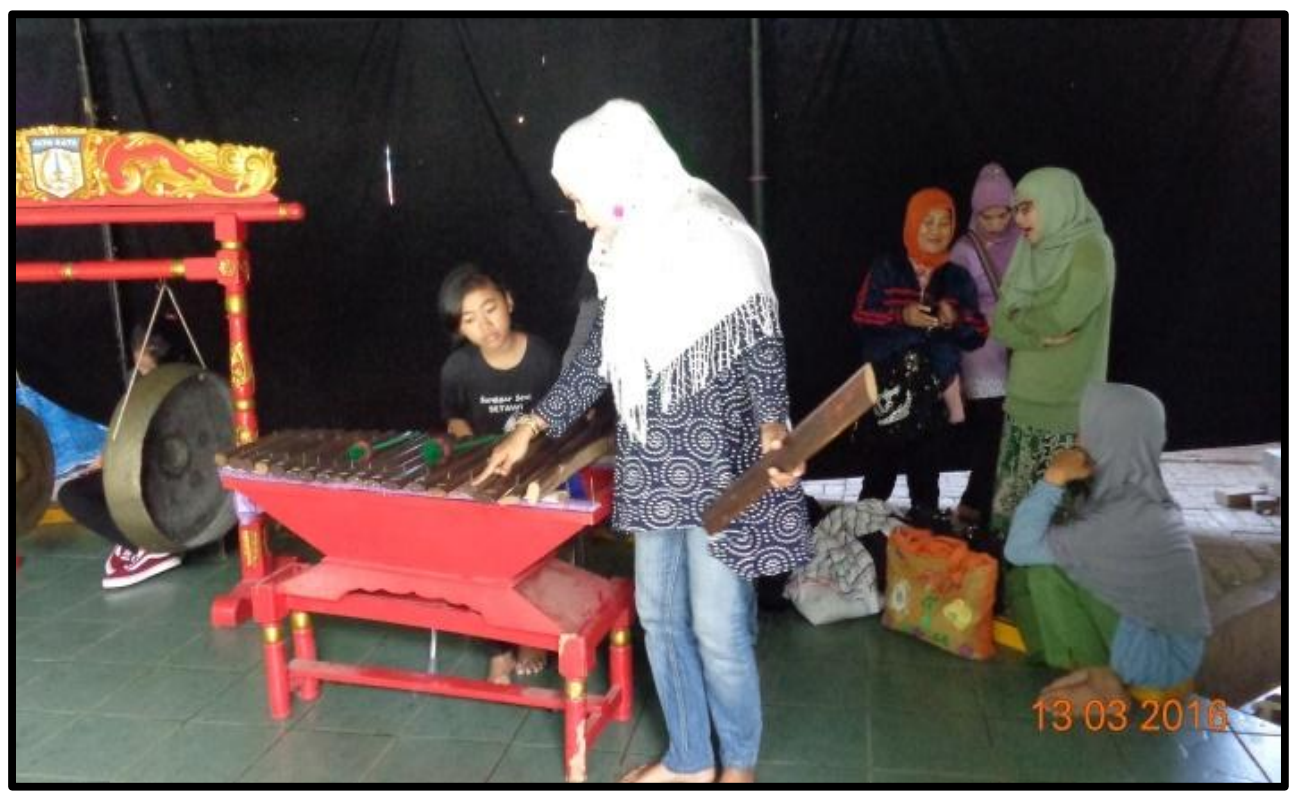

Gambar 4.3.2.7. Salah Satu Orang Tua yang Membantu Bang Andi Mengkondisikan Anak-anak Sebelum Latihan Dimulai (Foto: Marissa RH, 13 Maret 2016) 
Proses pembelajaran Gambang Kromong di Sanggar Seni Betawi Setu Babakan, menggunakan repertoar yang disusun oleh bang Andi. Tujuan bang Andi membuatkan repertoar tersebut agar anak lebih mudah mempelajari lagulagu Gambang Kromong dengan caramembaca pada awalnya, setelah beberapakali pertemuan latihan dan proses pembinaan, anak akan hafal dengan sendirinya tanpa teks lagu lagi. Pada buku repertoar musik Gambang Kromong tersebut, bang Andi memasukan lagu-lagu dalem (klasik), lagu sayur, maupun lagu-lagu modern. Bang Andi mengetik dan menyusun sendiri buku lagu dengan notasi angka tidakbakutersebut untuk mempermudah proses belajar anak didiknya, karena memang sebenarnya tidak ada penotasian tertulis dalam musik tradisi. Pewarisan musik tradisi yang tidak mengenal sistem penotasiandisebutkan olehMustopo (dalam Ejawati, 1998:15) yang menyampaikan beberapa ciri musik tradisi antara lain: (1)Berkembang dalam suatu komunitas, (2) Menggambarkan kepribadian komunal atau masyarakat setempat, (3) Menyuarakan semangat dan spirit kebersamaan masyarakat bersangkutan, (4) Senantiasa bersangkutan dengan kehidupan sehari-hari anggota komunitas, (5) Bersifat fungsional, dan (6) Proses pewarisannya tidak mengenal cara-cara tertulis. 

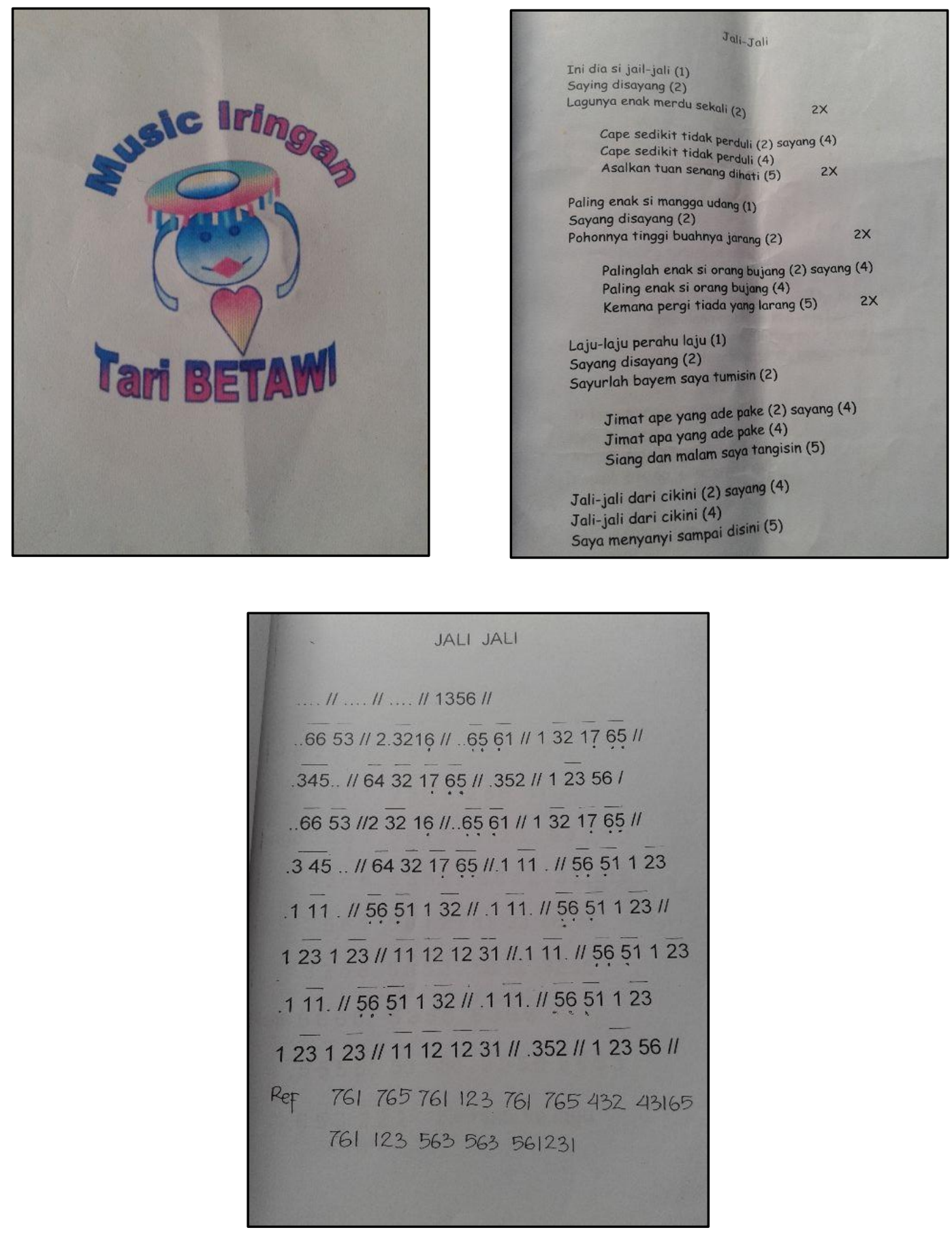

Gambar 4.3.2.8.Halaman Lagu Jali-jali dalam Repertoar Lagu yang Dibuat Oleh Bang Andi Untuk Membantu Mempermudah Proses PembelajaranMusik Gambang Kromong Bagi Anak Didiknya (Sumber: Orang Tua Fadhil Pemain Kromong) 


\section{JALI - JALI}

Lagu Daerah Jakarta

$$
\begin{aligned}
& \begin{array}{llll|lll|lll|lll}
0 & 0 & \overline{06} & \overline{65} & 3 & \overline{25} & 3 & 1 & 6 & 6 & \overline{0} & \overline{5}
\end{array} \\
& \text { I - ni di - a si ja-li ja-li. La-gunya }
\end{aligned}
$$

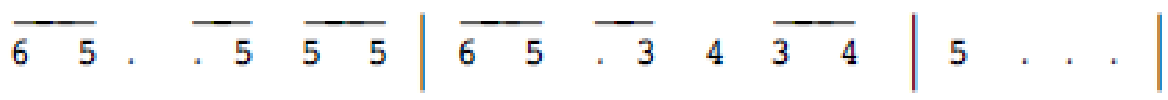

$$
\begin{aligned}
& \text { e-nak, la-gu nya e-nak, mer-du se-ka - li. } \\
& \begin{array}{lllll|llllllllll}
0 & 0 & 0 & 0 & : \| & 0 & 0 & \overline{0} & 5 & \overline{5} & 5 & \overline{1} 6 & -5 & 5 & \overline{5} 6
\end{array} \\
& \mathrm{Ca} \text { - pek se - di - kit ti-dak pe-du - } \\
& 4 \overline{3} 2 \ldots|2 \cdot \overline{5} \overline{55}| \overline{53} \cdot \overline{5} \overline{53} \\
& \text { li sa-yang, a - sal-kan tu - an, a-sal-kan }
\end{aligned}
$$

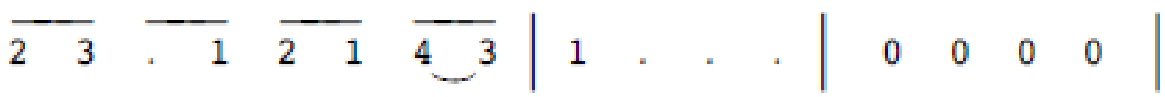

$$
\begin{aligned}
& \text { tu-an se-nang di ha - ti. }
\end{aligned}
$$

$$
\begin{aligned}
& \begin{array}{llll|lllll}
0 & 0 & \overline{0} & 5 & \overline{5} 5 & \overline{1} 6 & \overline{5} & 5 & \overline{5} 6
\end{array} \\
& \mathrm{Ja}-\mathrm{li} \text { lah ja- li la - gu Be - ta - }
\end{aligned}
$$

$$
\begin{aligned}
& 4 \overline{3} 2 .|2 \cdot \overline{5} \overline{55}| \overline{53} \cdot \overline{5} \overline{53} \\
& \text { wi sa-yang. Sa - ya me - nya - nyi, sa-ya me- }
\end{aligned}
$$




$$
\begin{aligned}
& \overline{23} \overline{-1} \quad \overline{2} 1 \overline{4} 3|1 \ldots| \begin{array}{lllll}
0 & 0 & 0 & 0
\end{array} \mid \\
& \text { nya-nyi meng-hi-bur ha - ti. }
\end{aligned}
$$

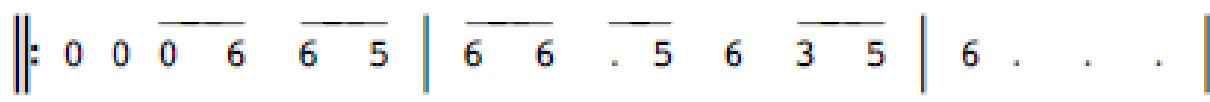

$$
\begin{aligned}
& \mathrm{Pa}-\text { ling-lah e - nak si mang-ga } u \text { - dang. } \\
& \begin{array}{lllllllllll}
0 & 0 & \overline{0} 5 & \overline{5} 5 & \overline{65} & -\overline{5} & \overline{5} 5 & \overline{65} & -3 & 4 & \overline{34}
\end{array} \\
& \text { Po-hon-nya ting-gi, po-hon-nya ting-gi bu-ah-nya ja- }
\end{aligned}
$$

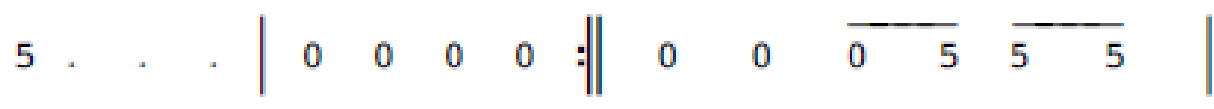

rang.

$$
\mathrm{Pa}-\text { ling lah }
$$

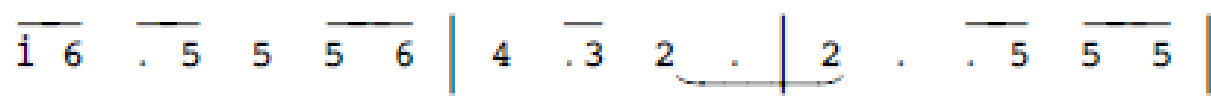
e-nak si o- rang bu-jang, sa-yang. $\mathrm{Ke}-\mathrm{ma}-\mathrm{na}$

$\overline{53} \cdot \quad$\begin{tabular}{ll|lllll}
5 & $\overline{5} 3$ & $\overline{2} 3$ & $\overline{1}$ & $\overline{2}$ & 1 & $\overline{4} 3$
\end{tabular}
per-gi,
ke - ma-na per-gi,

$1 .\left|\begin{array}{lllll|lllll}0 & 0 & 0 & 0 & 0 & 0 & \overline{0} & \overline{5} & 5\end{array}\right|$ rang.

$\mathrm{Ja}-\mathrm{li}$ lah

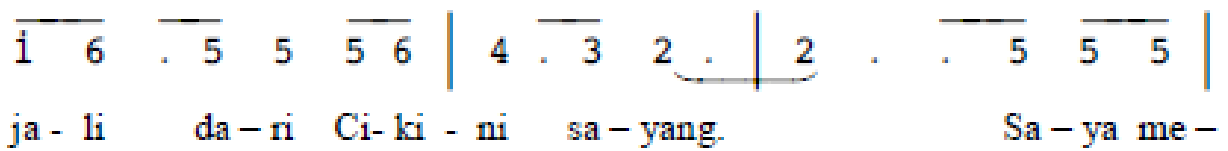

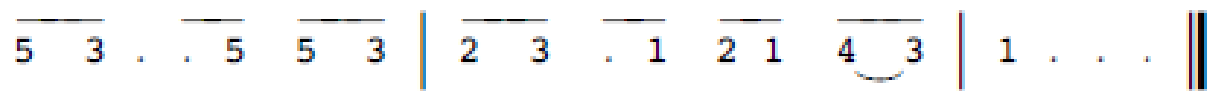
nya-nyi, sa - ya me-nya-nyi, sam-pai di - si - ni 


\section{JALI JALI}

Lagu Daerah Jakarta
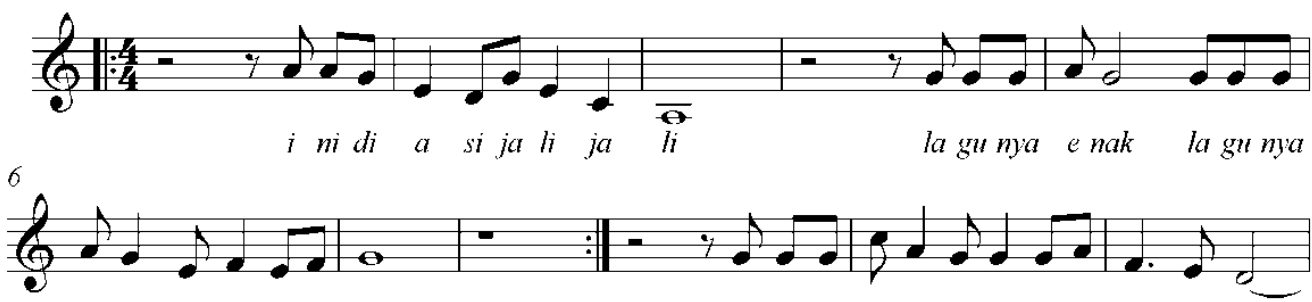
e nak, mer du se ka li capek se di kit ti dak pe du li sa yang12

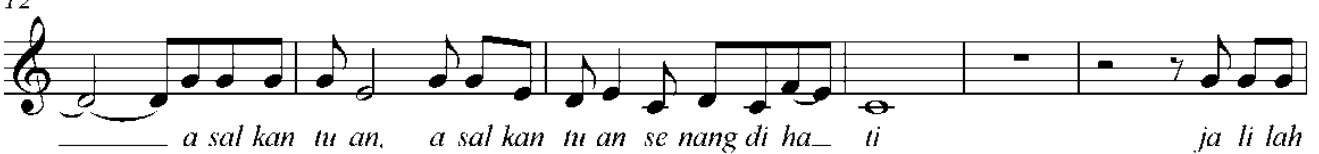
18

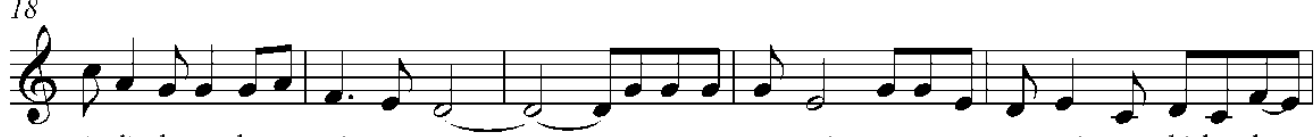
ja li la gu be la wi sa yang_ sa ya me nya nyi, sa ya me nya nyi meng hi bur ha_
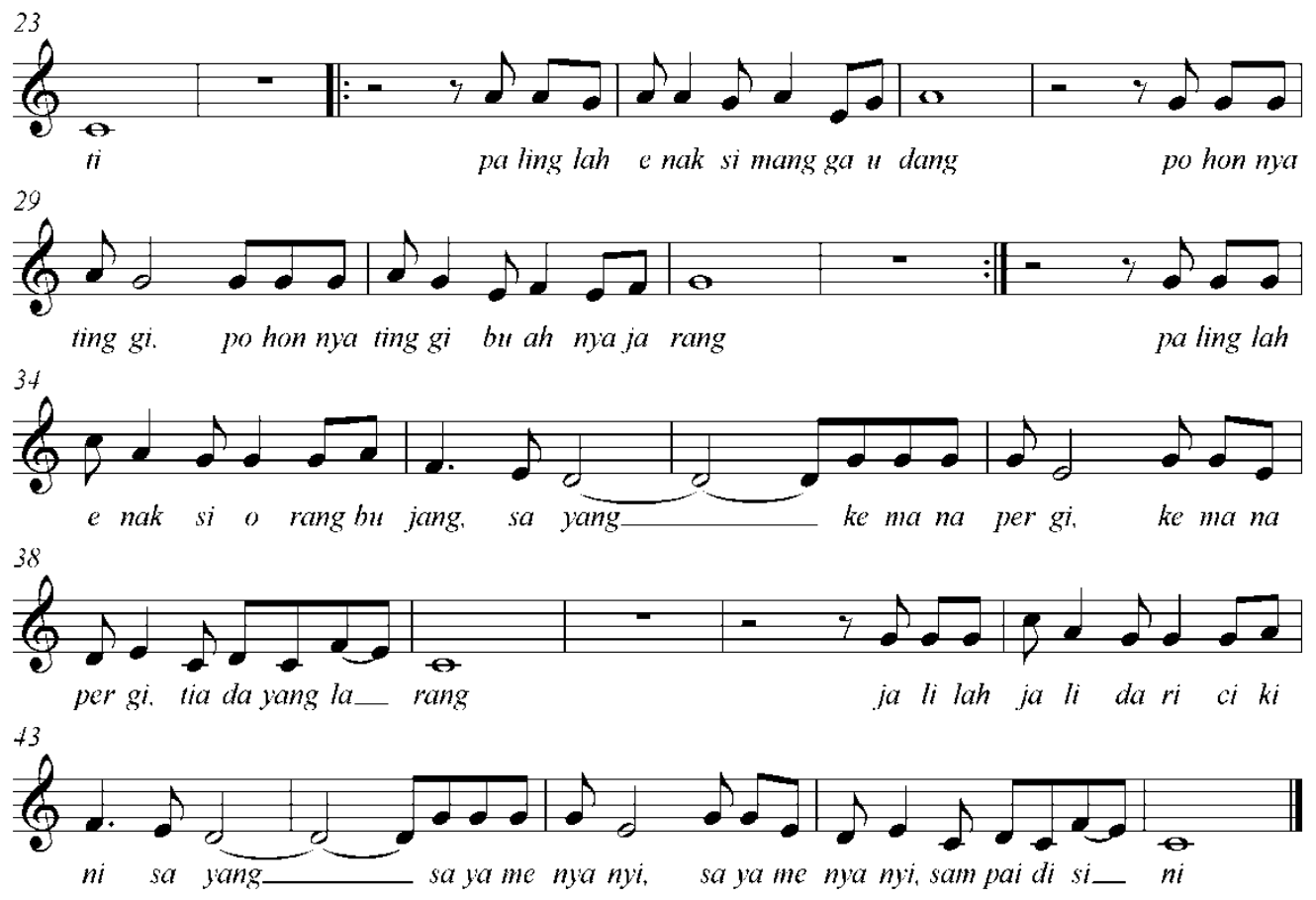


\subsubsection{Perubahan-perubahan Musik Gambang Kromong di Perkampungan Budaya Betawi dalam Proses Enkulturasinya}

Kenyataan yang terjadi adalah masyarakat selalu mengalami perubahan dalam perjalanan waktu yang dilaluinya.Apabila dilakukan perbandingan apa yang tejadi saat ini dengan beberapa tahun yang lalu, pastinya akan banyak ditemukan perubahan, baik yang direncanakan atau tidak direncanakan, cepat atau lambat, serta kecil ataupun besar. Perubahan-perubahan tersebut dilakukan sesuai dengan kebutuhan dan kondisi lingkungan sosial yang ada, dimana manusia selalu tidak puas dengan apa yang telah dicapainya, berdasarkan hal itu manusia selalu mencari sesuatu agar hidupnya menjadi lebih baik.Begitupula dengan kesenian, terjadi perubahan-perubahan yang dilakukan seiring laju perkembangan zaman agar bisa tetap bertahan dan berkembang di tengah masyarakatnya.Perubahanperubahan tersebut boleh kita sebut sebagai sebuah strategi adaptif dalam hal bagaimana kesenian itu beradaptasi dengan budayanya.

Gambang Kromong masa kini telah mengalami perubahanperubahan.Perubahan yang merupakan inovasi tersebut terjadi baik itu dalam hal fungsi musiknya, unsur instrumen penyusunnya, maupunlagu-lagu yang dibawakan.Melalui pengamatan dalam observasi lapangan, dan wawacara dengan beberapa narasumber, diketahui bahwa pada musik Gambang Kromong di Perkampungan Budaya Betawi Setu Babakan juga kian melakukan inovasi dalam musiknya.Inovasi yang dilakukan tentunya tidak mengubah rasa dari Gambang Kromong tersebut, laras pentatonis juga berubah menjadi diatonis karena masuknya instrumen-instrumen Barat. Dalam hal fungsi musik, dahulu Gambang 
Kromong biasa hadir sebagai musik pengiring wayang cokek dalam acara-acara seperti pesta tuan tanah, pesta-pesta perkawinan masyarakat Cina, dan sebagainya, sedangkan saat ini Gambang Kromong bisa tampil dalam acara hajatan-hajatan biasa, dan acara-acara pemerintahan seperti misalnya acara ulang tahun Jakarta, dalam acara di hotel-hotel untuk menyambut tamunya, dan sebagainya.Fungsi musik Gambang Kromong tidak berubah sejak dahulu, yaitu tetap sebagai musik hiburan.

Dahulu hal penampilan Gambang Kromong, dahulu pementasan musik ini selalu diawali dengan kegiatan membakar kemenyan, menyiapkan sesaji yang isinya seperti ayam, kembang 7 rupa, kopi pait, teh, susu, dan lain sebagainya dalam rangka ritual yang dimaksudkan untuk memberi "makan" alat-alat Gambang Kromong. Bahkan, instrumen-instrumen Gambang Kromong tersebut juga dimandikan pada waktu-waktu tertentu. Para panjak dahulupercaya apabila tidak melakukan ritual tersebut, pasti akan terjadi sesuatu yang tidak diharapkan ketika pentas berjalan.Namun, dalam masa sekarang ini, ritual seperti itu sudah tidak lagi dilakukan, mungkin masih ada, namun sudah sangat jarang ditemui karena manusia saat ini sudah memiliki paham religi yang lebih baik.Gambang Kromong dahulu merupakan bagian yang tidak bisa dipisahkan dari Cokek.Cokek memiliki arti kata menyanyi, sehingga Wayang Cokek adalah seorang penyanyi, namun mulai abad ke-19, Wayang Cokek yang harus menari sambil menemani tamunya bernyanyi, mengubah paham orang-orang menjadi Cokek adalah penari, bukan lagi sebagai penyanyi. 
Dalam pentas Gambang Kromong mengiringi Cokek pada masa dahulu, para penontonnya biasa melakukan ngibing.Lagu yang dibawakan saat ngibing adalah lagu sayur yang biasa ditempatkan pada akhir penampilan Gambang Kromong.Wayang cokek yang diiringi Gambang Kromong pada akhirpenampilan tersebut, kemudian bukan lagi hanya menyanyi untuk menghibur para tamu, tetapi juga ngibing bersama tamunya.Karena itu, lagu sayur terdengar lebih riuh dengan hentakan-hentakan gendang.Ngibing sendiri adalah kegiatan para Wayang Cokek yang menari bersama pasangannya dengan sebuah selendang yang disebut chiukhin, sama halnya seperti yang dilakukan tari Ronggeng. Para Cokek yang ngibing dengan diiringi Gambang Kromong tersebut berpakaian seronok, bahkan karena kegiatan ngibing tersebut, Wayang Cokek kemudian dianggap sebagai prostitusi dengan kedok kesenian tradisi.Bersyukur pada masa kini, Gambang Kromong dan Wayang Cokek tidak lagi melekat dengan hal-hal yang berbau negatif seperti itu.

Pertunjukan Gambang Kromong Sanggar Seni Betawi Setu Babakan pada masa kini secara urut dimulai dengan membawakan lagu-lagu dalem (klasik) yang berupa musik instrumental, setelah membawakan beberapa lagu dalem, dilanjutkan dengan memainkan lagu-lagu sayur dan modern.Vokalis dalam hal ini sudah bukan lagi Wayang Cokek, sudah ada vokalis sendiri untuk membawakan lagu-lagu Gambang Kromong.

Perubahan dalam unsur instrumen penyusunnya, saat ini Gambang Kromong di Perkampungan Budaya Betawi Setu Babakan juga telah menambahkan beberapa instrumen pendukung.Awalnya instrumen pokok 
Gambang Kromong berupa: Gambang, Kromong, Sukong, Tehyan, Kongahyan, 2 buah Gong, Gendang, Kecrek, dan Ningnong. Beberapa instrumen kemudian ditambahkan dalam Gambang Kromong masa kini, instrumen tambahan tersebut disesuaikan dengan aransemen lagu yang dibuat dan kreativitas para pemain. Beberapa instrumentambahan yang dipakai oleh Gambang Kromong di Sanggar Seni Betawi Setu Babakan diantaranya ada intrumen perkusi seperti, rebana, jimbe, ketimpring, sner drum, dan bedug, dan untuk tambahan instrumen Barat modern seperti, gitar elektrik, bass elektrik, dan saxophone. Seperti yang diutarakan bang Andi:

Kalau soal nambahin alat musik itu kita udah pasti sekarang. Ngikutin zaman, biar bisa tetep sesuai sama selera musik sekarang. Kita nambahin alat itu nyesuain aja sama aransemennya anak-anak, kita aransemen bareng, terus cocoknya ditambahin alat apa nih? Jimbe misalnya, gitar, bass, saxophone, suling, rebab, banyak dah.Lagu-lagu kita sekarang bawain juga lagu modern, kayak lagu-lagunyabang Benyamin tuh.

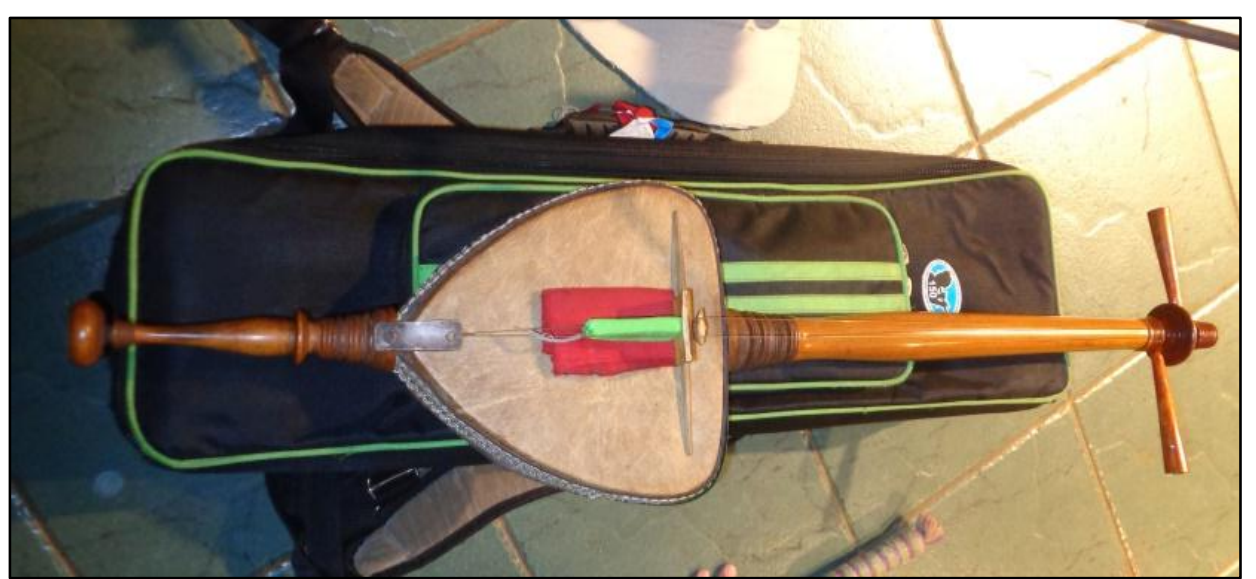

Gambar 4.3.3.1. Instrumen Rebab yang Kerap Dipakai Sebagai Instrumen Tambahan Dalam Kreativitas Musik Gambang Kromong (Foto: Marissa RH, 6 Januari 2016) 


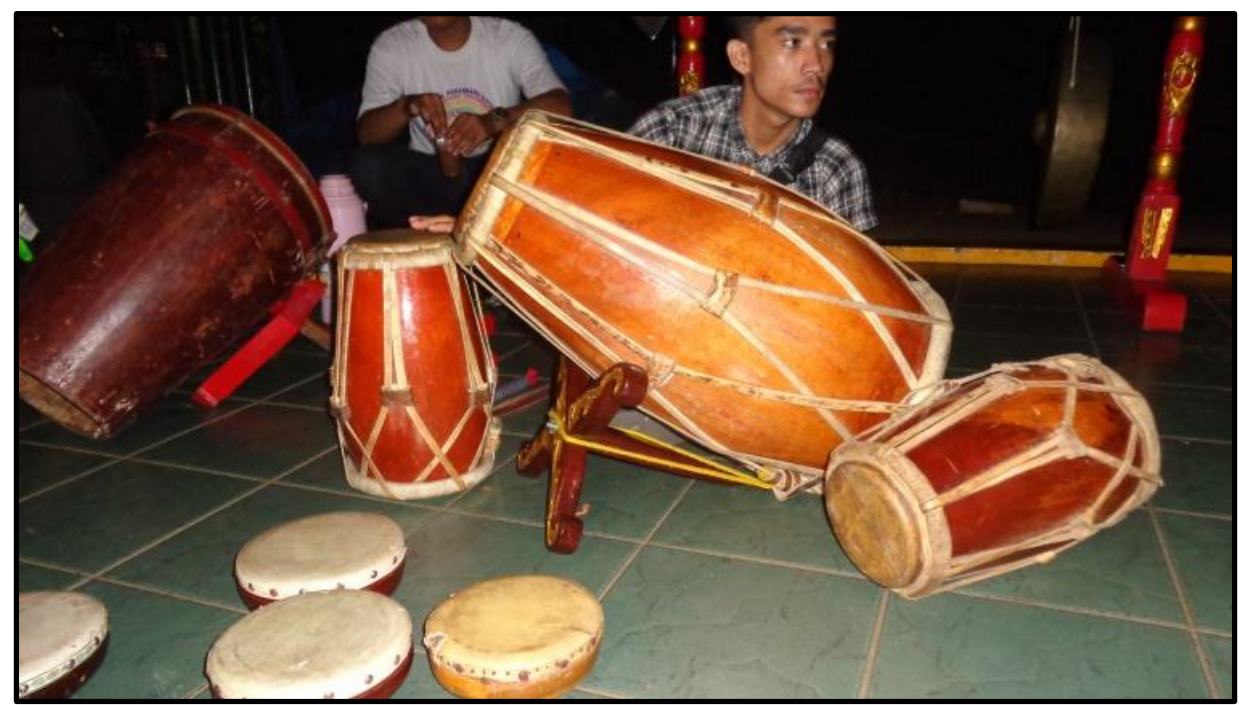

Gambar 4.3.3.2. Instrumen Rebana, Ketimpring, dan Bedug, yang Kerap Dipakai Sebagai Instrumen Tambahan Dalam Kreativitas Musik Gambang Kromong (Foto: Marissa RH, 6 Januari 2016)

Perubahan dalam unsur lagu, Gambang Kromong di Perkampungan Budaya Betawi Setu Babakan saat ini menambahkan repertoar lagunya, yang awalnya hanya lagu-lagu dalem dan lagu sayur, kini ditambahkan lagu-lagu Betawi modern. Lagu dalem (klasik) masih tetap dimainkan hingga saat ini, biasanya lagu-lagu dalem (klasik) dibawakan di awal penampilan, lagu tersebut diantaranya lagu centehmanis, renggong buyut, balo-balo, persi, dsb. Lagu sayur diantaranya ada lagu kicir-kicir, sirih kuning, lenggang kangkung, lagu-lagu langgam, dsb. Lagu modern yang biasa dibawakan dengan aransemen diantaranya seperti lagu ondel-ondel, gang kelinci, jali-jali, mirek, dan lagu-lagu dari Benyamin S (wawancara dengan bang Andi, 9 Maret 2016). 


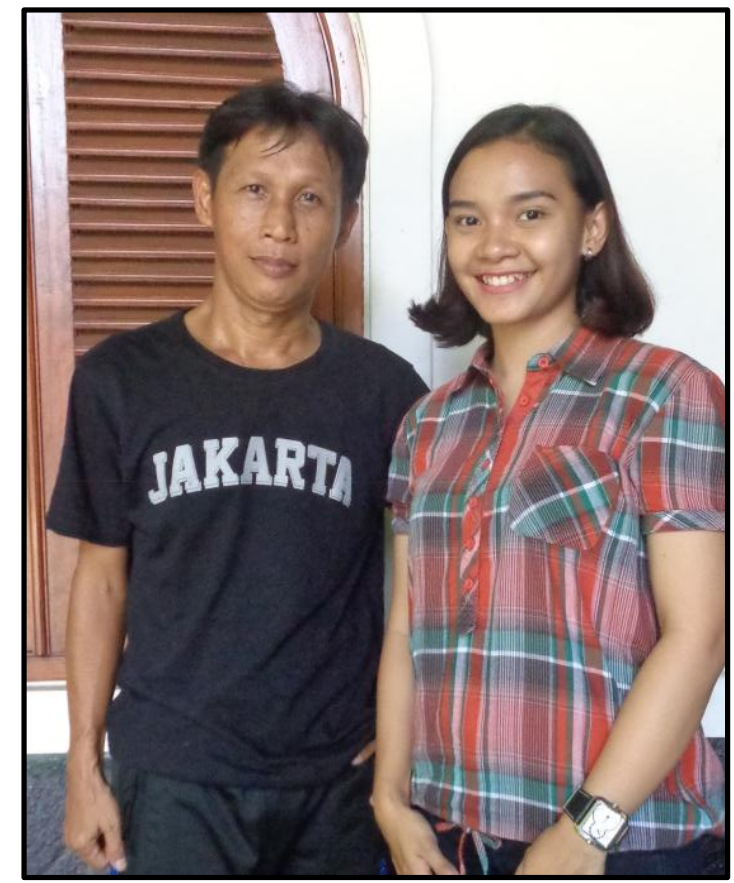

Gambar 4.3.3.3.Penulis dengan Bang Andi

(Foto: Marissa RH, 9 Maret 2016)

Perubahan-perubahan yang terjadi dalam musik Gambang Kromong tentunya dalam rangka upaya pemertahanan unsur kesenian tradisi Betawi ditengah banyaknya unsur-unsur budaya luar di tengah masyarakat masa kini. Melalui pengalaman-pengalaman penggunaan unsur kebudayaan yang baru dan yang lama, orang akhirnya menemukan mana yang lebih sesuai, dan itulah yang survive, sedangkan yang tidak sesuai lalu ditinggalkan (Joyomatono, 1991:40).Parsons (dalam Suwarsono, 1994:11) merumuskan istilah "fungsi pokok" (fungsional imperative) untuk menggambarkan empat macam tugas yang harus dilakukan agar masyarakat tidak "mati," yang dikenal dengan sebutan AGIL (adaptation, goal attainment, integration, and latency).Adaptation sendiri adalah suatu tindakan yang ditentukan pada sub sistem sosial agar tercapai suatu tujuan, 
dengan demikian, adaptasi fokus pada keharusan sistem sosial untuk menghadapi lingkungan dunia seni, yaitu penyesuaian terhadap kondisi perubahan diluar. Oleh karena itu, sistem yang dimaksudkan harus mampu melakukan inovasi dan transformasi aktif dengan menggunakan beberapa perkembangan teknologi dan sumber daya pada kelompok tertentu untuk dimanfaatkan sebagai alat dalam rangka mencapai tujuan yakni penyesuaian dengan perkembangan zaman.

Dalam tataran praktis, adaptasi ini bisa menjadi suatu upaya yang dilakukan oleh suatu kelompok, misalnya pada kelompok musik, mereka akan menyediakan sarana-sarana demi menunjang terealisasinya tujuan adaptasi mereka. Dalam konteks adaptasi musik tersebut, para personel di dalamnya mencoba mendesain ulang penampilan dengan keadaan lingkungan.Hal tersebut sesuai dengan temuan lapangan yang ada dalam musik Gambang Kromong di Perkampungan Budaya Betawi Setu Babakan yang kian melakukan inovasiinovasi untuk menyesuaikan diri dengan harapan bisa tetap diterima masyarakatnya pada masa kini.Penerimaan masyarakat dimulai dengan pengambilan kebiasaan baru oleh sejumlah kecil individu, dari titik itu mungkin hal tersebut kemudian tersebar (Joyomartono, 1991:39).

Inovasi yang kian terjadi dalam orkes Gambang Kromong baik itu dalam hal unsur instrumen musiknya, unsur lagu-lagunya, maupun unsur pertunjukannya merupakansebuah proses dimana kreativitas warga Betawi kemudian dapatditerima, dan dipraktekan oleh masyarakat pendukungnya. Joyomartono (1991:44-45) menyebutkan tiga konsep inovasi yang berbeda, yaitu:

1. Inovasi dalam pengertian sinonim dengan invention 
Inovasi menunjuk pada suatu proses kreativitas, yaitu kombinasi dari dua konsep atau lebih sehingga melahirkan sesuatu yang baru yang sebelumnya tidak diketahui oleh individu bersangkutan.Dalam pengertian ini, mereka yang inovatif adalah mereka yang berhasil merekayasa.

2. Inovasi dalam pengertian proses penerimaan

Inovasi diartikan sebagai proses pengambilan dan internalisasi atau proses memasarkan ide-ide baru.Dalam pengertian yang kedua ini, mereka yang inovatif adalah yang menerima ide baru itu, tidak perlu diperhatikan apakah ide baru itu rekayasa dia sendiri atau berasal dari luar dirinya atau organisasinya.

3. Inovasi dalam pengertian hasil invention

Inovasi dalam hal ini lebih menekankan pada hasil temuannya.Menurut Barnett (1953) mengemukakan bahwa inovasi adalah semua pemikiran, perilaku, atau hal-hal yang baru, karena hal itu secara kualitatif berbeda dengan bentuk-bentuk yang telah ada.

Perubahan-perubahan yang terjadi dalam perjalanan Gambang Kromong hingga bisa diterima masyarakat saat ini tentunya dapat terjadi karena beberapa faktor yang menjadi alasan.Salah satu faktor yang membuat perubahan tersebut dapat diterma masyarakatnya adalah, karena perubahan yang terjadi tidak mengubah nuansa atau bentuk asli dari Gambang Kromong, dan tidak bertentangan dengan nilai budaya yang dimiliki masyarakat Betawi. Menurut Rogers dan Soemaker (dalam Joyomartono, 1991:40) unsur baru akan sukar diterima apabila: (1) bertentangan dengan pola kebudayaan yang telah ada, (2) 
dapat mengakibatkan perubahan yang mendasar pada pola-polanya, (3) berkaitan dengan landasan dasar pandangan hidup atau nilai, dan (4) biayanya terlalu mahal.Sedangkan unsur yang baru akan mudah diterima apabila relatif lebih menguntungkan, sesuai dengan kebudayaan yang telah ada, mudah digunakan, dapat dicoba, dan dapat diamati. 


\section{BAB V}

\section{PENUTUP}

\subsection{Kesimpulan}

5.1.1. Musik Gambang Kromong yang saat ini ada dan berkembang di Perkampungan Budaya Betawi Setu Babakan, pada mulanya memang sudah ada di tengah masyarakat tersebut sejak sebelum ditetapkannya Perkampungan Budaya Betawi di wilayah mereka. Sejak tahun 1998 sudah ada kelompok Gambang Kromong Setu Lestari yang kemudian vakum. Tahun 2001, yaitu tahun dimana Perkampungan Budaya Betawi diresmikan oleh Pemda DKI. Melalui kehadiran Perkampungan Budaya Betawi, pemerintah turut mengelola kesenian tradisi Betawi di wilayah Setu Babakan melalui program pembinaan kesenian yang dibiayai oleh Pemda DKI Jakarta mulai tahun 2001. Program pembinaan kesenian tersebut menjadi cambuk dan batu lompatan bagi masyarakat sekitar Perkampungan Budaya Betawi, sehingga melalui swadaya masyarakat, mereka telah mendirikan sebuah wadahkesenianpada tahun 2002 berupa Sanggar Seni Betawi Setu Babakan, yang didalamnya terdapat musik Gambang Kromong yang terus dikelola dengan baik dan hingga kini terus berkembang di tengah masyarakat.

5.1.2. Proses enkulturasi musik Gambang Kromong di Perkampungan Budaya Betawi Setu Babakan terjadi melalui proses informal (keluarga dan lingkungan masyarakat) dan nonformal (sanggar). Dalam hal proses enkulturasi informal, 
keluarga seniman Gambang Kromong mewariskan kesenian tersebut melalui proses pelaziman, dimana anak dibiasakan mengenal, akrab, dan dengan sendirinya akanmenyukai, dan bermain musik Gambang Kromong tanpa adanya paksaan. Proses enkulturasi melalui lingkungan masyarakat terjadi karena adanya interaksi sosial yang mempengaruhi individu lain untuk turut mempelajari kesenian Gambang Kromong tersebut. Sedangkan proses enkulturasi melalui sanggar dilaksanakan secara teratur dan terprogram dalam latihan rutin di Sanggar Seni Betawi Setu Babakan, yaitu pada hari Minggu pagi dan Jumat malam.Tahapan proses pewarisan Gambang Kromong di Sanggar Seni Betawi Setu Babakan meliputi tahap perkenalan, melihat, meniru, dan proses pembinaan.

\subsection{Saran}

Berdasarkan kesimpulan yang diperolehdalam penelitian ini, penulis memberikan saran bagi masyarakat Betawi, untuk terus mencintai dan melestarikan kesenian Gambang Kromong dan kesenian Betawi lainnya yang kian tergerus oleh perkembangan zaman. Khususnya bagi para generasi muda agar bangga, menyukai, dan tidak malu untuk mempelajari kesenian tradisi bangsa Indonesia yang harus tetap dijaga kelestariannya, karena kebudayaan yang dikelola dengan baik akan menghasilkan sebuah makna dan menjadi identitas bagi masyarakat bersangkutan. Bagi pemerintah DKI Jakarta, agar tanpa rasa jemu, dapat terus mendukung masyarakatnya dalam hal yang berkaitan proses pembudayaan kesenian tradisi, salah satunya melalui peningkatan kegiatankegiatan yang di dalamnya melibatkan penampilan dari berbagai kesenian tradisi Betawi.Pemerintah DKI Jakarta juga dapat memasukan muatan lokal yang 
mengandung pengenalan unsur-unsur kebudayaan Betawi, dengan demikian para generasi penerus juga dapat mengenal kebudayaannya melalui pendidikan formal di sekolah. 


\section{REFERENCES}

Abdulgani, Ruslan. 1963. Penggunaan Ilmu Sejarah. Bandung: Prapanca

Ali, Mohamad. 1985. Penelitian Kependidikan, Prosedur dan Strategi. Bandung: Angkasa

Ambarwangi, S., \& Suharto, S. (2014). REOG AS MEANS OF STUDENTS' APPRECIATION AND CREATION IN ARTS AND CULTURE BASED ON THE LOCAL WISDOM. Harmonia: Journal Of Arts Research And Education, 14(1), $37-45$. doi:http://dx.doi.org/10.15294/harmonia.v14i1.2789

Arikunto, Suharsimi. 2002. Metodologi Penelitian. Jakarta: PT. Rineka Cipta

Atoshoki, Antonius. 2011. "Enculturation Pengaruh Lingkungan Sosial Terhadap Pembentukan Perilaku Budaya Individu”. Jurnal Humaniora. April 2011. Vol 2.Nomor 1. Hlm. 139-150. Jakarta: Bina Nusantara University

Budhisantoso, S. "Kesenian dan Kebudayaan".Wiled Jurnal Seni STSI Surakarta.Agustus 1994.Jilid 5.Hlm 3-5. Surakarta: STSI Press Surakarta

Chasanah, S.U. 2014.Penerimaan Masyarakat Betawi Muslim Terhadap Kesenian Musik Gambang Kromong dan Tari Ronggeng Blantek di Perkampungan Budaya Betawi Setu Babakan.Skripsi. Jakarta: Universitas Islam Negeri Syarif Hidayatullah Jakarta

Dinas Kebudayaan dan Permuseuman Pemerintah Provinsi Daerah DKI Jakarta. 2002. Ragam Budaya Betawi. Jakarta: Pemerintah Provinsi Daerah DKI Jakarta Dinas Kebudayaan dan Permuseuman

Dinas Kebudayaan Provinsi DKI Jakarta. 2000. Seni Budaya Betawi: Pralokakarya Penggalian dan Pengembangannya. Jakarta: Dinas Kebudayaan Provinsi DKI Jakarta

Suharto, S., \& Aesijah, S. (2014). THE LESUNG MUSIC IN THE VILLAGE OF LEDOK BLORA REGENCY. Harmonia: Journal Of Arts Research And Education, $14(1)$

65-71. doi:http://dx.doi.org/10.15294/harmonia.v14i1.2851

Putra, B. (2013). PENGEMBANGAN MODEL KONSERVASI KESENIAN LOKAL SEBAGAI KEMASAN SENI WISATA DI KABUPATEN SEMARANG. Harmonia: Journal Of Arts Research And Education, 12(2). doi:http://dx.doi.org/10.15294/harmonia.v12i2.2525

Tarwiyah, T. (2011). PELESTARIAN BUDAYA BETAWI PERMAINAN ANAK CICI PUTRI DAN ULABANG/ WAK WAK GUNG : KAJIAN KANDUNGAN KECERDASAN JAMAK. Harmonia: Journal Of Arts 
Research

And

Education,

$10(1)$.

doi:http://dx.doi.org/10.15294/harmonia.v10i1.51

Tarwiyah, T. (2011). ANALISIS NILAI-NILAI PENDIDIKAN DALAM LAGULAGU DAERAH BETAWI (An Analysis of Educational Values in Songs of the BetawiArea). Harmonia: Journal Of Arts Research And Education, 5(1). doi:http://dx.doi.org/10.15294/harmonia.v5i1.831

Irianto, A. (2016). The Development of Jathilan Performance as an Adaptive Strategy Used by Javanese Farmers. Harmonia: Journal Of Arts Research And Education, 16(1), 38-48. doi:http://dx.doi.org/10.15294/harmonia.v16i1.5213

Hapsari, L. (2014). FUNGSI TOPENG IRENG DI KURAHAN KABUPATEN MAGELANG. Harmonia: Journal Of Arts Research And Education, 13(2). doi:http://dx.doi.org/10.15294/harmonia.v13i2.2780

Budiarti, M. (2011). MENGUBAHÂ CITRA LENGGER MENJADIÂ MEDIA EKSPRESIÂ ESTETIS (To Change the Image of Lengger Into Esthetic $\hat{A}$ Medium of Expression). Harmonia: Journal Of Arts Research And Education, 4(2). doi:http://dx.doi.org/10.15294/harmonia.v4i2.708

Darmasti. "TARI SESAJI PANGENTAS BILAHI SUDRA TINGAL." Harmonia: Journal of Arts Research and Education [Online], 12.2 (2012): n. pag. Web. 24 Sep. 2017

Close

Ejawati, Ninik. 1998. Bentuk Penyajian dan Fungsi Kesenian Tradisional Odrot di Desa Sumberejo Kecamatan Balong Kabupaten Ponorogo.Skripsi. Semarang: Universitas Negeri Semarang

Fathoni, Abdurrahmat. 2006. Antropologi Sosial Budaya. Jakarta: PT Rineka Cipta

Hasanah, R. 2014.Strategi Adaptasi Kelompok Musik Gambang Kromong Dalam Menghadapi Perubahan Sosial (Studi Kasus Kelompok Musik Gambang Kromong Mustika Forkabi).Skripsi. Jakarta: Universitas Islam Negeri Syarif Hidayatullah Jakarta

Ihromi, TO.1990. Pokok-pokok Antropologi Budaya. Jakarta: Yayasan Obor Indonesia

Joyomartono, Mulyono. 1991. Perubahan Kebudayaan Masyarakat Dalam Pembangunan. Semarang: IKIP Semarang Press

Koentjaraningrat. 1986. Pengantar Ilmu Antropologi. Jakarta: PT. Rineka Cipta 
1990.Pengantar Ilmu Antropologi. Jakarta: PT. Rineka Cipta

Kuntjara, Esther. 2006. Penelitian Kebudayaan Sebuah Panduan Praktis. Yogyakarta: Graha Ilmu

Kwa, David. 2005. "Lebih Dalam Tentang Gambang Kromong dan Wayang Cokek". Jurnal Kesenian Cisadane. Juni 2005.Nomor 5. Tangerang: Dewan Kesenian Tangerang

Lestari, Wahyu. 1998. Proses Sosialisasi, Enkulturasi dan Internalisasi Dalam Pengajaran Seni Tari Pada Sekolah Lanjutan Tingkat Pertama Negeri di Kabupaten Sleman Daerah Istimewa Yogyakarta. Tesis. Yogyakarta: PPs IKIP Yogyakarta

Liliweri, Alo.1997. Sosiologi Organisasi. Bandung: PT Citra Aditya Bakti

Mardani, dkk.2014. Setu Babakan dari Penelitian ke Penelitian. Jakarta: Dinas Pariwisata dan Kebudayaan Provinsi DKI Jakarta Bekerjasama dengan Lembaga Pengelola Perkampungan Budaya Betawi Setu Babakan.

Moleong, Lexy J. 1998. Metodologi Penelitian Kualitatif. Bandung: PT. Remaja Rosdakarya

_, 2000.Metodologi Penelitian Kualitatif. Bandung: PT. Remaja Rosdakarya

Muhadjir, Noeng. 1989. Metodologi Penelitian Kualitatif. Yogyakarta: Bayu Indra Grafika

Muhammad Ali. 1985. Penelitian Pendidikan Prosedur dan Strategi. Bandung: Angkasa

Mulanto, Joko. 2015. Tari Kretek: Pewarisan Bentuk, Nilai, dan Maknanya. Skripsi. Semarang: Universitas Negeri Semarang

Pemerintah Provinsi Daerah Khusus Ibukota Jakarta Dinas Kebudayaan dan Permuseuman.2002. Ragam Budaya Betawi Provinsi DKI Jakarta. Jakarta: Pemprov DKI Jakarta Dinas Kebudayaan dan Permuseuman

Rohidi, Tjeptjep Rohendi. 2000. Kesenian dalam Pendekatan Kebudayaan. Bandung: STISI 1990.Pengantar Ilmu Antropologi. Jakarta: PT. Rineka Cipta 1992. Analisis Data Kualitatif. Jakarta: UI Press

Ruchiat R, Wibisono S, Syamsudin R. 2003. Ikhtisar Kesenian Betawi. Jakarta: Dinas Kebudayaan dan Permuseuman Propinsi DKI Jakarta.

Rustam, E. 1999.Pengantar Ilmu Sejarah, Teori Filsafat Sejarah, Sejarah Filsafat, dan IPTEK. Jakarta: Rineka Cipta 
Sedyawati, Edi. 1981. Pertumbuhan Seni Pertunjukan. Jakarta: Sinar Harapan. 2006.Budaya Indonesia : Kajian Arkeologi, Seni, dan Sejarah. Jakarta: Raja Grafindo Persada

—, 2014.Kebudayaan di Nusantara Dari Keris, Tor-tor, Sampai IndustriBudaya.Depok. Komunitas Bambu

Sugiyono. 2008. Metode Penelitian Kuantitatif Kualitatif dan R\&D. Bandung Alfabeta

2011.Metode Penelitian Kuantitatif, kualitatif dan R\&D. Bandung: Alfabeta

Sumaryanto, Totok. 2014. Metodologi Penelitian Kualitatif Untuk Pendidikan Seni. Semarang: Jurusan Pendidikan Sendratasik, Fakultas Bahasa dan Seni, Universitas Negeri Semarang

Suwarsono, 1994.Perubahan Sosial dan Pembangunan, Teori Modernisasi, Dependensi, dan Sistem Dunia.Jakarta: LP3ES

Tindaon, R. 2012. “Kesenian Tradisional dan Revitalisasi”.Jurnal Ekspresi Seni. November 2012. Vol 14.Nomor 2.Hlm. Padang: ISI Padang Panjang

Triyanto. 2015. Enkulturasi Perkeramikan Pada Komunitas Perajin Desa Mayong Lor Jepara: Strategi Adaptasi dan Pemberlanjutan Potensi Kreatif Kebudayaan Lokal.Disertasi. Semarang: Universitas Negeri Semarang

Yahya, A. S, Nurzain. 2009. Profil Seni Budaya Betawi. Jakarta: Dinas Pariwisata dan Kebudayaan Provinsi DKI Jakarta 


\section{LAMPIRAN}

Lampiran 1

\section{PEDOMAN OBSERVASI}

\section{Tujuan Observasi}

Observasi pada penelitian ini dimaksudkan untuk mengetahui bagaimana kondisi terkini orkes musik Gambang Kromong di Perkampungan Budaya Betawi Setu Babakan Jakarta Selatan.

\section{Hal-hal yang diobservasi}

Hal-hal yang diobservasi dalam penelitian ini antaralain:

a. Gambaran umum lokasi penelitian.

b. Struktur organisasi pengelola Perkampungan Budaya Betawi Setu Babakan Jakarta Selatan.

c. Struktur organisasi kelompok musik Gambang Kromong di perkampungan budaya Setu Babakan Jakarta Selatan.

d. Kegiatan rutin yang dilaksanakan kelompok musik Gambang Kromong di perkampungan budaya Setu Babakan Jakarta Selatan.

e. Apresiasi masyarakat pendukung di lingkungan perkampungan budaya Betawi Setu Babakan terhadap orkes musik Gambang Kromong.

\section{Metode Observasi}

Pelaksanaan observasi dalam penelitian ini dilakukan melalui cara terjun langsung ke lokasi penelitian untuk mengadakan pengamatan terhadap subjek yang diteliti. Dalam observasi, digunakan pedoman observasi dan alat bantu berupa buku catatan dan kamera digital. Melalui observasi ini diharapkan mampu memperoleh gambaran yang konkret mengenai orkes musik Gambang Kromong di perkampungan budaya Betawi Setu Babakan Jakarta Selatan. 
Lampiran 2

\section{PEDOMAN WAWANCARA}

\section{Tujuan Wawancara}

Wawancara dalam penelitian ini dilakukan dengan tujuan mengetahui bagaimana sejarah keberadaan orkes musik Gambang Kromong di perkampungan budaya Setu Babakan dan bagaimana proses enkulturasi musik Gambang Kromong di Perkampungan Budaya Betawi Setu Babakan berlangsung.

\section{Pembatasan}

Dalam melakukan wawancara, peneliti membatasi materi wawancara dalam lingkup:

a. Sejarah terbentuknya orkes Gambang Kromong di Perkampungan Budaya Betawi Setu Babakan.

b. Faktor-faktor yang menghambat proses enkulturasi orkes musik Gambang Kromong di Perkampungan Budaya Betawi Setu Babakan.

c. Faktor-faktor yang mendukung proses enkulturasi orkes musik Gambang Kromong di Perkampungan Budaya Betawi Setu Babakan.

d. Apresiasi masyarakat di lingkungan Perkampungan Budaya Betawi Setu Babakan terhadap orkes musik Gambang Kromong.

\section{Informan}

6.1. Pengelola Perkampungan Budaya Betawi Setu Babakan Jakarta Selatan meliputi:

Beberapa hal yang akan disampaikan sebagai pertanyaan wawancara

a. Kapan Setu Babakan ditetapkan sebagai Perkampungan Budaya Betawi oleh pemerintah?

b. Bagaimana sejarah berdirinya Perkampungan Budaya Betawi Setu Babakan?

c. Bagaimana asal-usul musik Gambang Kromong dapat berada di wilayah Perkampungan Budaya Betawi Setu Babakan?

d. Bagaimana kondisi Setu Babakan saat ini dalam hal mendukung kelestarian orkes Gambang Kromong khas Betawi? (faktor pendukung dan penghambat)

\subsection{Ketua Sanggar Seni Betawi Setu Babakan} meliputi:

Beberapa hal yang akan disampaikan sebagai pertanyaan wawancara

a. Sejak kapan orkes Gambang Kromong berada di Perkampungan Budaya Betawi Setu Babakan?

b. Bagaimana asal-usul orkes Gambang Kromong berada di Perkampungan Budaya Betawi Setu Babakan ini?

c. Saat ini, anda adalah generasi keberapa dari keturunan orkes Gambang Kromong di Setu Babakan ini?

d. Bagaimana sistem kepengurusan orkes Gambang Kromong ini?

e. Berapa jumlah pemain tetap kelompok musik Gambang Kromong di Setu Babakan ini?

f. Apakah para personil merupakan masyarakat asli suku Betawi? 
g. Prestasi apa saja yang sudah pernah diraih orkes Gambang Kromong ini dalam kiprahnya di masyarakat?

h. Sebesar apa intensitas tampil dalam pentas yang biasa dijalankan oleh orkes ini?

i. Lagu-lagu apa saja yang biasa dibawakan saat pentas oleh orkes Gambang Kromong Setu Babakan?

j. Dukungan apa yang biasa diterima orkes Gambang Kromong ini saat melakukan pentas-pentas, dan darimana dukungan tersebut berasal?

k. Bagimana respon masyarakat sekitar terhadap keberadaan musik Gambang Kromong ini?

1. Menurut anda, bagaimana kondisi Gambang Kromong dalam keberadaannya ditengah masyarakat saat ini?

\subsection{Pemain Musik Gambang Kromong Setu Babakan} meliputi:

Beberapa hal yang akan disampaikan sebagai pertanyaan wawancara

a. Apakah anda bermain Gambang Kromong sejak kecil?

b. Bagaimana anda mengenal musik Gambang Kromong hingga tergabung dalam kelompok musik Gambang Kromong di Setu Babakan ini? Dan Sudah berapa lama bergabung dalam orkes Gambang Kromong di Setu Babakan?

c. Apakah anda adalah masyarakat asli suku Betawi?

d. Apa kendala yang anda temui selama mengikuti Gambang Kromong ini? 
Lampiran 3

\section{PEDOMAN STUDI DOKUMEN DAN DOKUMENTASI}

\section{Tujuan Studi Dokumen dan Dokumentasi}

Studi dokumen dilakukan dengan tujuan memperoleh data-data tambahan yang mendukung penelitian ini.Data-data tersebut berupa dokumen, baik dalam bentuk laporan, statistik, surat-surat resmi, maupun cacatan harian dan semacamnya baik yang diterbitkan, maupun tidak diterbitkan.Dokumentasi dimaksudkan untuk mengambil foto-foto terkait masalah penelitian ini.Dokumentasi dalam penelitian ini menghasilkan foto kondisi lingkungan Perkampungan Budaya Betawi, foto kegiatan-kegiatan rutin terkini yang dilakukan kelompok Gambang Kromong Setu Babakan, dan sebagainya.

\section{Pembatasan}

Dalam hal ini, studi dokumen dilakukan dengan mengumpulkan data seperti:

a. Dokumen foto Gambang Kromong di Setu Babakan,

b. Berita-berita terkait Gambang Kromong di Setu Babakan,

c. Data-data lain berkaitan dengan Gambang Kromong Setu Babakan Jakarta Selatan. 
Lampiran 4

\title{
TRANSKRIP WAWANCARA
}

\section{Transkrip Wawancara dengan Bang Indra Sutisna Selaku Anggota Lembaga Pengelola Perkampungan Budaya Betawi}

\author{
Hari/Tanggal : Jumat, 25 Maret 2016 \\ Waktu $\quad: 09.00 \mathrm{WIB}$ \\ Lokasi : Zona Embrio Perkampungan Budaya Betawi
}

1. Bagaimana sejarah berdirinya Perkampungan Budaya Betawi? Dan tanggal berapa diresmikannya oleh Pemerintah Provinsi DKI Jakarta?

Jawab: Ketika Jakarta dengan segala macem budayanya yang ada disini, tapi kita pahami ini bukan budaya Betawi, dari masyarakat init kota Jakarta kaum Betawi, ini membuat tokoh-tokoh Betawi, budayawan, pemerhati, merasa ada keterpanggilan karena dia merasa miris dengan budaya masyarakatnya yang terus menurun dan hampir hilang, fakta itu harus kita akui. Kalaupun Condet dengan SK Gubernur tahun 1974 oleh pak Ali Sadikin saat itu, itukan tidak serta merta mereka cipta wilayah itu. Dari tahun 1974 regulasi barangkali gak begitu kuat, sehingga reward and punishment tidak berjalan baik.Berpikir lagi, Condet sudah ada, sekitar tahun 90an kita cari tempat lagi deh, yang lebih representative, lebih memenuhi syarat buat tempat pelestariann budaya.Artinya, inikan ada kesepakatan kolektif dari masyarakat.Akhirnya kita coba, bahasanya sesederhana itu.Kalau di Jakarta Utara gimana? Kan ada Marunda tuh, kita cek, Cuma ada masjid Al-a'lam dan rumah bang Pitung. Tapi begitu kita lihat kesana gak ada komunitas, gak terlalu banyak, sehingga kan sulit nanti kalau kita bikin perkampungan tapi ga ada masyarakatnya, tempatnya juga pinggir laut, kalau rob atau kenapa-kenapa. Akhirnya kita geser ke daerah tengah, kita lihat kemayoran, kemayoran dari peruntukan dan fungsinya itu sudah mendekati niaga, kulturnya juga tidak begitu kental, modern, dan lebih rame, inikan agak sulit, kita pengennya yang agak-agak bernostalgia gitu.Kita bergeser lagi ke daerah Barat. Disana ada daerah Kembangan, tapi disana gak ada apa-apa, cuma ada hutan kota, itu rekacipta total dari pemerintah. Sampai akhirnya tahun 1994/1995 kita masih mencari, bergeser ke Jakarta Selatan, di sana ada setu, di Jakarta Selatan paling pinggir, karena $2 \mathrm{~km}$ lagi udah batas kota Depok. Akhirnya, kita laporin ke Pemda bahwa dari antara beberapa tempat, ini yang paling memungkinkan.Kita lakukan pembicaraan, bagimana kalau kita bikin action, Pemda mendukung. Tanggal 13 September 1997, dibuat acara "Sehari di Setu Babakan", itu kan berati udah Pemda, dengan leading sectorSuku Dinas Pariwisata Jakarta 
Selatan. Nah, artinya ada sebuah dukungan cukup kuat dari Pemda dengan kebijakan bottom up ini.Akhirnya dilakukan pengkajian, bener gak sih bahwa dari antara yang lain, ini yang terbaik. Antusiasnya tinggi masyarakatnya, ada lomba menghias atau lomba getek, kendaraan air tradisional, loma masak sayur asem, dan sebagainya. Antusias yang cukup tinggi dan kuat ini menjadi bahan atau modal yang luar biasa, selain ada asset Pemda yang cukup besar. Seharusnya dari tahun 1997 itu kita ada eksekusi di tahun 1998, tapi kita tau sendiri di tahun 98 itu ada apa aja, ada 98 kelabu, dan sebagainya kita chaos. Karena itu, kan sulit diambil regulasi, gak ada action, gak ada kegiatan apaapa, sampe pada akhirnya tahun 1999 ada keputusan, ayo kita kuatin bahwa ini harus terus berjalan, digodok terus, diadakan lokakarya, kajian, dan sebagainya, oleh pemerintah juga kita diajak bicarain. Sampai akhirnya, kalau kita mau ngebangun, kita mau mulai disini kan harus ada regulasi, akhirnya muncul regulasi, tanggal 18 Agustus 2000 ditetapkan SKnya, SK Gubernur No 92 tahun 2000. Artinya kalau udah dari Agustus, masuk ke September oke sudah ada regulasi dan bisa dimulai.15 September 2000 dilakukan peletakan batu pertama. Kita akan merancang berapa bangunan? 4 pada waktu itu, pintu gerbang Bang Pitung, panggung teater terbuka, wisma, sama contoh rumah adat. Ke-empat bangunan itu dibangun, berjalan, kita anggap selesai untuk tahap pembuatan awal, tinggal tahap perampungan nanti.Tanggal 20 Januari 2001, berdekatan dengan lebaran, kita buat acara peresmian Perkampungan Budaya Betawi tahap awal.Jadi sejak saat itu orang-orang sudah boleh mulai datang melihat yang sedikit ini.Biar lebih rame gimana?Ya sekali waktu Sudin atau Dinas bikin action acara sekali waktu disini, temen-temen yang mau tugas dateng kesini gimana?Ya boleh dateng.Kita berpikir juga kemudian bahwa kita perlu tempat informasi, dulu tempat informasi cuma sebuah kamar kecil banget ukurannya, di contoh rumah adat, itu buat nerima-nerima tamu.Bagaimana kalau kita buat lagi tempat?Ya sudah, akhirnya kita bangun lagi ini embrio, akhir tahun 2001.Artinya bahwa pembangunan itu gak secara masif, jadi ini bertahap, bahkan terkesna sporadis karena dulu tidak ada perencanaan yang sangat detail.Disini memang ada rekacipta, namun ada tahapan-tahapan.Saya lanjut, ketika Perkampungan Budaya Betawi sudah mulai ada, masyarakat dateng dan segala macemnya, kita berpikir ini regulasi harus lebih kuat. Kalau cuma SK aja nanti jangan-jangan nasibnya kayak Condet nih, ada terpikir kaya begitu. Gimana kalau ada yang lebih kuat satu tingkat di atasnya berupa Perda? Kita godok lagi.Kita kejar.Hingga akhirnya, tanggal 10 Maret 2005, ketok palu dah tuh, Peraturan Daerah Nomor 3 Tahun 2005.Kan udah ada SK?Kenapa ada Perda lagi? Iya ada SK, tapi kalau waktu itu SK ada, ini tidak berjalan baik, kita bisa saja pindah lagi, karena take line SK "penataan Perkampungan Budaya Betawi di Setu Babakan kelurahan Srengseng Sawah". Penataan. Kita ingin satu tingkat lebih kuat, karena ada berpikirnya kita bisa aja pindah, boleh aja, tapi setelah kita lihat perjalanannya 5 tahun atau 4 tahun ini cukup baik, cukup signifikan, tinggal barangkali tata kelolanya aja yang diperbaiki. Udah tinggal perbaiki aja regulasinya, ngapain mikirin ke yang lain-lain, kita fokus disini. Maka, bunyi di Perda itu "Penetapan Perkampungan Budaya Betawi di Setu Babakan kelurahan 
Srengseng Sawah". Cuma yang beda adalah, kalau tadi di SK luasnya 165ha, begitu berubah jadi Perda luasnya jadi 289ha, ada wilayah lain yang dimasukan ke dalam wilayah Perkampungan Budaya Betawi. Nah, begitulah regulasi, cerita tentang Perkampungan Budaya Betawi, lantas apa dan bagaimananya jelas ada konsep tata kelola yang belum selesai, bakal kita lengkapin, terus tadi sudah kita liat benang merahnya, dari awal masyarkat, tokoh-tokoh, organisasi kebetawian, bisa kita sebut Lembaga Kebudayaan Betawi, cendekiawan, budayawan Betawi, itu memang bersama-sama ingin mewujudkan tempat ini. Akhirnya, dari SK itu udah muncul namanya "Perkampungan Budaya Betawi".Konsepnya Perkampungan Budaya Betawi kita berpikir bahwa itu kampung yang memang direka cipta.Kalau kita nyebutnya kampung Betawi itu barangkali penduduknya harus mayoritas sangat orang Betawi semua. Tapi ketika ada kata Perkampungan Budaya Betawi, dia ada arti sederhananya itu, kampung yang direka cipta bernuansa kebetawian, baik fisik maupun nonfisik, konsep sederhananya kayak begitu. Kira-kira kronologis singkat dari Perkampungan Budaya Betawi yang di dalam Perkampungan Budaya Betawi itu ada Setu Babakan yang umurnya lebih dari 100 tahun, Setu Manggabolong, Setu ISTN, cuman karena folklore yang mengalir, orang lebih mengenalnya dengan Setu Babakan. Perkampungan Budaya Betawi kan bahasa promonya kurang, masyarakat gak begitu cepet lah hal-hal yang begitu, dia pengen yang sederhana aja, Setu Babakan.

2. Saat ini kondisi mata pencaharian masyarakat sekitar Setu Babakan seperti apa?

Jawab: Pencaharian sudah banyak bergeser juga non, waktu lalu misalnya dia berkebun, bercocok tanam, tapi ketika bergeser mungkin dari tahun 1980an yang lebih keliatannya ya ada program pemerataan, urbanisasi masuk, listrik ok, transportasi masuk, urbanisasi gak bisa dicegah, ada kampus-kampus baru disini, mulai deh bergeser. Kita gak bisa hanya ngandelin ini, kebutuhan hidup semakin tinggi. Ketika ini ada Perkampungan Budaya Betawi ini kan tadi udah berjalan, jadi ada yang memang bergeser ke niaga, biarpun basic itu memang sudah banyak berjualan karena adanya Perkampungan Budaya Betawi, tapi ada juga yang sudah masuk kantor-kantor pemerintah, kantorkantor swasta, di jasa misalnya, buruh tetap ada tapi gak terlalu banyak saat ini, kemudian profesional sudah mulai ada. Kalau kita nyebut konsultan itu kan udah profesional, dokter juga profesional, ada dokter yang sudah S2 di sini, tapi yang telibat dalam pengelolaan Perkampungan Budaya Betawi sebagai pegawai, kita mendahulukan masyarakat disini, jadi ada nilai positif secara ekonomi dengan adanya Perkampungan Budaya Betawi di sini. Kemudian ada juga yang bikin kontrakan, dan segala macemnya, yang di Polri juga ada walaupun gak banyak.

3. Sedikit masuk ke Gambang Kromong bang, asal muasal sanggar seni Betawi disini bagaimana? 
Jawab: Ya. Ketika Perkampungan Budaya Betawi ada, dengan judul, dengan namanya Perkampungan Budaya Betawi, itukan harus ada identitas budaya. Identitas budaya yang bisa kita dapet apasih?Banyak hal, dari mulai lahir sampe meninggal, prosesi adat oke, kita masuk di tata graha oke, tata busana, kuliner, seni, budaya, itu bagian. Seni budaya ada apa aja di dalemnya? Ya banyak macemnya, kalau kita mau liat tari, kita mau liat musik, kita mau liat teater atau drama entah lenong atau apa segala macem, kita liat pencak silat, folklore, dialek, bahasa segala macem. Nah salah satu waktu itu yang berpeluang bisa dikembangkan, dan bisa menginteraksi masyarakat, kemudian juga bisa menjual, itu adalah seni. Kalau hanya tata graha aja itukan statis, kalau seni kan dinamis. Nah kemudian dihidupkan lagi dan mengenalkan kepada masyarakat. Selain dikasih yang sifatnya took down, misalnya pemerintah: ada dari sanggar lain, yuk nampil di Perkampungan Budaya Betawi, untuk ngeramein. Tapi berpikir laen, masa si sanggar laen, orang kampung sini kalau gak ade sanggarnya ya gimane? Begitu.Oke, coba deh bikin sanggar disini, awalnya begitu.Awalnya Pemda kasih begitu, dan masyarakat nangkep, memang ada disini, coba aja. Ternyata begitu di angkat, masyarakat sekitar ada yang muncul, walaupun yang tua-tua, misalnya, ada nyak siapa itu dia tukang jual gado-gado, dia umurnya sekarang udah 70 tahun lebih, tapi ketika dia dagang, kemudian ada musik, dicoba latihan awal, dengan tenaga instrukturnya dari Pemda, nyanyinya bagus. Kita Tanya, "nyak, kok bisa nyanyi gini?", kata dia, "lah, kan dulu emak nyanyi keliling-keliling tong, kalau ada hiburan-hiburan ngikut emak". O, berate darah seninya ada. Tanya lagi, "pak Diding, bapak main suling?", kata dia "iya, dulu ikut grup....". O, berati ada juga darah seninya. Terus anak-anak mudanya gimana?Kalau dari kami sangat autodidak.Oke, kalau begitu, sumbang seperangkat alat musik, silahkan gunakan, pakai latihan disini. Nah, ini udah lebih hidup, udah lebih bagus, yuk bagaimana kalau anak-anaknya diajak, ditarik berapa orang, dengan tenaga instrukturnya dari sini, kemudian tenaga autodidak yang ada disini diberdayakan, nanti pada saatnya, kita lepas biar dia bermandiri. Dan keuntungan kalau sanggar ini kita bentuk adalah, mereka bisa peran langsung disini. Kalau sanggar yang laen kan dia nunggu dipanggil dimana dimana, tapi disini, mudah-mudahan ada peluang yang bagus, orang berkunjung, kita butuh, gaperlu manggil yang laen-laen. Karena kan kecenderungannya kita mengedepankan apasih nilai yang bisa mereka dapat, walaupun keuntungan yang bukan semata-mata idealisme gitu ya, o ada pengakuan, o dia dikenal orang, atau bahkan ada nilai ekonomi. Maka, ketika ada keuntungan itu, akan ada pendukungan dari awal itu. Ya akhirnya, terus berjalan, oke anda harus bikin sanggar ini, pengurusnya begini-begini segala macem pendirinya, kemudian dibina oleh Dinas Kebudayaan dan Permuseuman waktu itu, karena belum merger ya, merger itu waktu itu tahun 2009 kalau gak salah dengan pariwisata. Nah, kemudian masuklah yang akhirnya dikondisikan berjalan.Dan betul, ketika ada kebutuhan penari, yaudah ini dah ada anak-anak udah pada mulai nari kecil-kecil, ibu-ibu mau latihan gak? Ya ayo latihan. "Bu, tuh ada acara pertemuan ibu-ibu Gubernur Nasional di Brawijaya, Kebayoran Baru. Latihan ya?", yaudah pada latihan, 
berangkat ibu-ibu maen biarpun cuma 1 atau 2 musik. Artinya, ada pencerahan itu.Dari situ semakin dikuatkan, dan tenyata benar yang kita prediksi, ketika ada orang kunjungan, kenapa yang dicari yang lain-lain?Ini aja udah diberdayain.Dan anak-anak itu punya rasa kebanggaan tersendiri, waktu dia latihan aja udah ditonton orang.Tapi kita juga gak memanjakan setiap latihan dia tampil terus dikasih uang, dikasih uang, gak begitu.Kita tumbuhkan, rasa peduli, untuk dia cinta kepada budayanya.Nah dari awal situ akhirnya jadi lebih kuat dan bahkan kita bisa merekomendasi sanggar ini pembinaannya cukup baik.Jadi dia bisa tampil disini, bisa juga kita rekomendasikan kalau ada kegiatan ke daerah-daerah, atau provinsi laen, bahkan kalau memang ada kesempatan untuk keluar negeri. Faktanya, si pelatih, bang Andi itu beberapa kali ke luar negeri, entah lewat kampus, entah lewat Pemda, entah lewat perusahaan atau apa. Itukan sebuah peluang yang baik ya biar mereka juga engga kuper, engga apasi ya, kesannya tradisi tuh cuma musik yang ketinggalan, engga sekedar itu, mereka punya inovasi tanpa menghilangkan makna awal atau makna intinya.Kira-kira kurang lebih seperti itu.

4. Bagaimana faktor-faktor pendukung dan penghambat di Perkampungan Budaya Betawi ini dalam hal menyangkut pelestarian kesenian Gambang Kromong?

Jawab: Kalau pendukungnya kita udah jelas, mereka kita minta silahkan latihan disini, mereka latihan, secara free, kita siapin juga tempatnya. Ini kita sedang usulkan harus ada tempat lagi yang lebih representatif misalnya semacam belandongan, ya kaya saung angklung mang Ujo gitu ya.Ini sebenarnya udah cukup, tapi kita pikir kalau ada lagi lebih baik.Kemudian tadi berkaitan dengan pendukung juga, karena banyak kunjungan budaya disini, maka dia menjadi hidup, ketimbang sanggar tempat laen.Kalau sanggar laen kesini, mereka harus berongkos.Ya faktor pendukung disini berjalan cukup banyak.Kalau Gambang Kromong ini mau tampil ke luar dari tempat ini juga boleh, silahkan, ada sekolah yang perlu bikin acara, ya anak-anak kesana. Penghambatnya kemudian apa? Ada masalah cara berpikir, pendanaan bisa, fasilitas bisa, sarana prasarana bisa, SDM, atau tenaga pelatih. Nah, yang saya maksud mindset, cara berpikir mereka itu bisa aja seorang ibu nih melatih anaknya atau menempatkan anaknya disini hanya untuk sekedar berapresiasi, tidak dalam konsep yang jangka panjang untuk mengembangkan budaya. "Saya pengen anak-anak saya biar kenal sama temen-temennya, biar berani", hanya sekedar sampai itu, dan itu sebenernya gak salah. Nanti ketika anak udah gede dikit, udah SMP, mulai ada pertanyaan lingkungan "kok latihannya yang tradisi-tradisi?", begitu SMA misalnya dia kenal dan dapet temen cowok nanya lagi, "kok eneng latihannya masih begituan aja sih? Kan itu udah jadul", begitu.Akhirnya dia ikut yang moder, nge-band, begitu misalnya, misalnya yak.Tapi fakta itu kita dapetin, waktu menjadi sangat berperan disini, dan itu gabisa kita hindarin, kita bermain dengan waktu, bermain dengan mindset. Budaya itu kan tipis banget, ketika mereka konsepnya kuat budaya maka terus bertahan, tapi juga sangat mudah untuk bergeser, karena 
dia itukan dinamis. Kalau misalnya bangunan hari ini begini, oke, yasudah bangunan mah kan diem aja, paling masalah pemeliharaan, tapi kalau masyarakat? Gak bisa.Kalau orang?Gak bisa. Hari ini dia sangat cinta, walaupun barangkali dipaksa sama orang tuanya yang dia mau, besok belom tentu. Kadang-kadang dia cinta tanpa ada paksaan aja dengan budaya, bisa sangat bergeser.Pengaruh yang sangat kuat di luar ini bisa menjadi pemicu. Pengaruh budaya global yang luar biasa, bisa menjadi pemicu, "o ini udah gak modern, kita harus yang seperti ini, seperti ini....".Itu semua sangat luar biasa. Artinya, kita ingin ini dijadiin filter, Perkampungan Budaya Betawi untuk anak-anak kita, untuk generasi-generasi kita agar kultur, atau nilai-nilai budaya itu bisa terserap oleh mereka. Tapi lagi-lagi karena budaya ini sangat tipis, gak ada polisi budaya, perubahan-perubahan itu keniscahyaanya adalah kita gak bisa hindari, dia akan muncul kapanpun, dan di diri orang itu sangat rentan dengan itu. Karena bisa aja ketika orangtuanya berpikir, "iya ya, ngapain juga, mendingan kerja neng, kuliah udah mahal-mahal”, ideal itu, rasional kalau orang tua berpikir seperti itu.Sehingga, hal-hal yang seperti ini boleh kita bilang menjadi tantangan, atau hambatan ekstrem begitu. Karena ketika kebutuhan mereka untuk hidup belum tercukupi, pikirnya belom penuh, hatinya belom penuh, kantongnya dan perutnya belom penuh, idealisme kan belom bisa muncul kuat. Bahkan ketika itu semua udah penuh juga belom tentu, karena dia bisa menggeser nilai-nilai tadi, dia hanya berpikir pada profit misalnya seperti itu. Kecuali kalau ada benang merah yang sangat kuat, dari keluarga, warisan budaya dari sana walaupun lompat ini bisa tetep turun di berikutnya, bisa sangat mungkin begitu. Jadi, ini saya pikir lumayan banyak lah tantangan-tantangan buat adek-adek kita, buat anak-anak kita, buat pemerhati budaya, buat budaya itu sendiri, buat Pemda.Tapi ada peran dikedua-duanya untuk itu, kalau Pemda dan masyarakat kuat, ya budaya itu bisa mengalir baik.

5. Bagaimana rencana kedepan terkait kesenian-kesenian yang ada di Perkampungan Budaya Betawi ini?

Jawab: Dalam konsep pelestarian dan pengembangan budaya, kemudian kita ingin ini sebagai tempat wisata budaya, ada peran-peran disitu. Jadi ada yang sifatnya mentah, ada yang mateng. "nah, ntuh ada anak-anak lagi pada latihan", itu mentah tuh, tapi itu bisa dikonsumsi biarpun mentah, gak apa-apa. Orang dateng seneng liat anak-anak lagi pada latihan di hari minggu, di hari rabu sore, malem sabtu, itu rutin, silahkan.Tapikan gak bisa yang mentah aja, yang matengnya gimana?Yang mateng itu seharusnya disetiap hari minggu, seharusnya. Tapi karena anggaran Pemda memang seperti itu belum turun di 1 atau 2 atau 3 bulan awal, nanti barangkali di bulan April sudah bisa. Nah, peran Pemda disitu.Satu, dia bisa menghidupkan sanggar-sanggar, anda kalau panggilan lagi sepi, anda bisa tampil disini, tapi aturannya ini, ini, ini.Bukan kami mau mempersulit, biar anda juga benar secara administrasi. Nah itu perna Pemda, dia harus menggunakan dana, dia harus mengalokasikan dana dengan nilai cukup besar agar sanggar yang ada di 5 wilayah ini, sanggar apapun bisa tampil disini sebagai bagian dari peran Pemda untuk pelestarian 
dan pengembangan budaya. Itu kana da di Undang-undang no 29 tahun 2007 bab 5 pasal 26 ayat 6 tuh kalau gasalah ya, Pemerintah provinsi DKI Jakarta melestarikan dan mengembangkan budaya Betawi, serta menjaga budaya masyarakat lain yang ada di wilayah Jakarta. Itulah peran Pemda, tinggal masyarakatnya mau gak?Kalau masyarakat mau, itu semua berjalan.Nah ini konsep kita, nilai-nilai budaya melalui kesenian itu tadi bagian tak terpisahkan dalam konsep pelestarian dan pengembangan budaya Betawi, dan itu harus ada.

\title{
Transkrip Wawancara dengan Bang Sahroni Selaku Ketua Sanggar Seni Betawi Setu Babakan
}

\author{
Hari/Tanggal : Rabu, 23 Maret 2016 \\ Waktu $\quad: 13.00 \mathrm{WIB}$ \\ Lokasi : Z Zona A Perkampungan Budaya Betawi
}

1. Bagaimana sejarah berdirinya Sanggar Seni Betawi Setu Babakan?

Jawab: Jadi gini non, sebelum ada Perkampungan Budaya Betawi, disini udah ada grup-grup kesenian kayak Lenong, Gambang Kromong, lupa saya nama grupnya karena udah lama ya. Seiring dengan berjalannya waktu, modernisasi, akhirnya vakum. Nah sekitar tahun 1998, di kampung Setu Babakan ini ada kelompok tani, namanya "Setu Lestari", kita dapet bantuan alat musik Gambang Kromong. Akhirnya kita belajar dengan alat musik Gambang Kromong yang ada, tapi akhirnya vakum juga, alat musik masih ada, karena maklum dah yang belajar bapak-bapak gitu.Tahun 2001, diresmikan Perkampungan Budaya Betawi yang terletak di Setu Babakan.Ada program dari Pemda DKI melalui Dinas Kebudayaan, namanya pembinaan kesenian.Yang dibina ada Musik Gambang Kromong, tari, dan teater, pelatihnya didatengin dari Dinas.Tujuannya merekrut masyarakat terutama remaja-remaja sekitar Setu Babakan untuk berlatih dan memperlajari kesenian Betawi. Terus 2002, secara otomatis kita berpikir, kebetulan saya juga bekerja disitu, saya juga pengurus, kita berpikir bahwa yang namanya program dari pemerintah itukan tergantung dana. Kalau dananya satu tahun ya satu tahun, kalau dananya buat dua tahun ya dua tahun, setelah itukan akan hilang begitu saja. Nah minat atau animo masyarakat yang sudah besar untuk belajar kesenian akhirnya akan terputus. Di sekitar sini saat itu sudah tidak ada wadah, tidak ada tempat untuk mereka latihan, tidak ada sanggar.Akhirnya kita bentuk, kita bikin aja udah, kita bikin sanggar.Kesepakatan, namanya apanih? Adanya Setu Babakan, yaudah kita bikin namanya "Sanggar Seni Betawi Setu Babakan". Di dalam sanggar ini melatih tari, musik yaitu 
Gambang Kromong, ada teater yaitu Lenong.Terus berjalan, Alhamdulillah, antusias masyarakat sekitar dan di luar Perkampungan Betawi dari Pasar Minggu, Depok, dan sekitarnya itu cukup rame.Kalau tidak salah untuk sekarang ini, secara administrasi anggotanya sudah lebih dari 600 peserta.Kalau silat beksi itu mulai masuk tahun 2007, berati sekarang udah kurang lebih sekitar 8 tahun tuh beksi.

2. Bang Sahroni adalah generasi kepengurusan sanggar yang keberapa?

Jawab: Kalau kepengurusan sanggar, saya yang ke-2. Yang pertama itu bapak Romi Rojali.Pada awalnya saya ditunjuk sebagai ketua itu gak mau, saya pengennya ngedukung dari belakang aja, tapi akhirnya saya dipilih untuk jadi ketua.

3. Sistem kepengurusan Sanggar Seni Betawi Setu Babakan seperti apa?

Jawab: Ya kita kepengurusan atau administrasinya ada struktur organisasinya ada ketua, sekretaris, bendahara, staff itu ada pelatih, pelatih musik bang Andi, pelatih tari bang Andi, pelatih silat itu bang Toyib, dan ada asisten-asisten pelatihnya.

4. Jumlah pemain tetap Gambang Kromong di Sanggar Seni Betawi Setu Babakan ada berapa orang?

Jawab: Kita Gambang Kromong itu selalu beregenerasi. Dari tahun 2002 sampe sekarang ini aja udah ada 3 generasi, ini sekarang kita lagi ngedidik lagi yang kecil-kecil, ntar mereka dewasa jadi lagi generasi ke-4. Jadi, jumlah pemainnya tidak tetap karena ada regenerasi itu.

5. Apakah para pemain Gambang Kromong di Sanggar Seni Betawi Setu Babakan adalah orang-orang asli Betawi?

Jawab: Oh, engga. Campur-campur.Kita gak khusus, walaupun seninya seni Betawi, tapi untuk personilnya gak harus orang Betawi, siapa mau main, main aja, terbuka kok.

6. Pencapaian apa saja yang sudah diraih oleh Gambang Kromong di Sanggar Seni Betawi Setu Babakan ini?

Jawab: Tahun 2015 kemaren kita juara ke-2 lomba tari kreasi yang diiringi Gambang Kromong, itu tingkat Dinas. Tahun 2003, 2004, 2005 sebagai duta seni pelajar se-Jawa Bali.2006 kita mewakili DKI Jakarta dalam acara musik tradisi nusantara di TMII.Masih banyak juga yang lainnya.

7. Bagaimana intensitas tampil Gambang Kromong di Sanggar Seni Betawi Setu Babakan di tengah masyarakat ini?

Jawab: Kalau Gambang Kromong kita Alhamdulillah, untuk acara pemerintahan dan acara di luar, pasti paling tidak itu satu bulan satu kali bakal ada tampil. 
8. Dalam acara apa saja Gambang Kromong di Sanggar Seni Betawi Setu Babakan ini biasa tampil?

Jawab: Kalau Gambang Kromong itu yang rutin disini kalau ada kunjungankunjungan, kunjungan dari pihak sekolah, kunjungan dari pemerintahan. Kalau lagi ada kunjungan misalnya dari sekolah, itu pasti ada pementasan musik Gambang Kromong dan tari.Terus kunjungan dari pemerintahan, kemaren Sabtu itu kita baru abis tampil kunjungan dari MPR acara sosialisasi budaya. Belom lagi di tempat-tempat kayak hotel, acara hajatan, pesta-pesta nikahan.

9. Lagu-lagu apa saja yang biasa dibawakan Gambang Kromong di Sanggar Seni Betawi Setu Babakan ini saat tampil?

Jawab: Lagu yang dibawain kita biasanya lagu-lagu klasik, lagu modern seperti lagu-lagu bang Benyamin. Kalau di Gambang Kromong Betawi itu kan biasanya lagu pokok itu Jali-jali, Cente Manis. Kalau pas maen lagu-lagu modern itu musiknya ditambah dengan bass gitar, gitar melodi, dan keyboard, tapi kalau yang kalasik ya biasa alat gambang, kromong, tehyan, kecrek, gong, dan beberapa aja.

10. Dukungan apa saja yang didapat Gambang Kromong di Sanggar Seni Betawi Setu Babakan ini? Dan darimana asal bantuan tersebut?

Jawab: Kalau bantuan kayak sponsor itu, tahun 2013 kemaren kita dapet bantuan dari Kementrian Pendidikan dan Kebudayaan. Kita ngajuin proposal, kita dapet nominalnya kurang lebih Rp146.500.000,-. Kita ngajuinnya alat, yang turun berupa uang, jadi kita belanjain sendiri. Kalau buat yang lain-lain, sebenernya siapa sih yang gak mau dapet bantuan, tapikan kita punya tanggung jawab moral juga, kemaren saya ditawarin lagi dari LKB kalau mau ngajuin bantuan dari Kemendikbud, tapi saya bilang, "mohon maaf bang, saya udah dapet tahun 2013 kemaren, ya mungkin buat temen-temen yang laen aja bantuannya"

11. Bagaimana respon masyarakat Perkampungan Budaya Betawi maupun sekitarnya terhadap kesenian Gambang Kromong saat ini?

Jawab: Respon masyarakat disini cukup bagus ya, antusias. Kalau kemaren kamu liat latihan anak-anak itu kan animonya cukup besar ya. Kalau masyarakat sekitar, sebenernya awal kita ngebuat sanggar itukan buat melestarikan dan mengembangkan budaya Betawi, karena disini kan menjadi Perkampungan Budaya Betawi, suatu saat yang namanya Perkampungan Budaya Betawi yang tampil itu ya kesenian Betawi, kalau disini kita ada wadah, ada sanggar, silahkan mereka belajar segala macem, entah tari, entah silat, entah musik Gambang Kromong, entah teater, suatu saat kita dibutuhkan kita udah siap. Ibarat kata, kita jadi pemain di kampung sendiri, bukan penonton. Kalau ada pementasan atau apa disini, jangan yang tampil darimana-mana, masyarakat sini yang tampil. Tapi untuk masyarakat sekitar sini, Setu Babakan, baru-baru aja sih mereka antusias, tapi belakang ini mungkin kendor atau gimana, mungkin yang remaja udah pada sibuk kerja 
segala macem, mungkin anggepannya berkesenian itu bukan suatu hal yang menjanjikan menurut dia, bekerja itu lebih cepet dapet uang dibanding mereka belajar kesenian. Tapi kan yang penting niat kita udah mengajak, kalau dia pada gak mau yaudah bukan urusan kita.

12. Menurut bang Sahroni, bagaimana kondisi Gambang Kromong secara umum saat ini di tengah besarnya arus modernisasi yang menggerus kesenian tradisi? Jawab: Sekarang kondisinya Alhamdulillah membaik. Setelah ada Perkampungan Budaya Betawi, secara otomatis, kesenian-kesenian Betawi yang ada di Jakarta dan sekitarnya minimal 1 tahun sekali akan tampil. Yang awalnya tidak ada, sekarang ada, yang awalnya gak punya sanggar, sekarang membentuk sanggar.Satu contoh, wilayah Bunga Cimpedak, sekarang dia udah buka sanggar namanya "Bunga Cimpedak".Ada di daerah Ciganjur juga dia buka sanggar juga. Karena apa? Dengan adanya Perkampungan Budaya Betawi mereka berpikir suatu saat akan tampil disini. Ada beberapa sanggar yang pengen tampil disini. Dulu waktu saya kecil memang Lenong, Topeng Betawi, itu banyak ditemui di tempat-tempat orang pesta, tapi setelah tahun 80an masuk video, mulai berkurang, masuk lagi layar tancep, makin berkurang, masuk lagi bioskop 21, makin abis udah. Di Setu Babakan tadinya ada 2 grup Gambang Kromong, terus vakum, tapi karena ada Perkampungan Budaya Betawi sekarang mereka bangkit lagi. Sekarang Gambang Kromong yang ada di Jakarta dan sekitar sudah mulai berkembang lagi dan mulai merintis lagi dari awal, banyak grup-grup baru, banyak generasi-generasi baru, yang dari kakeknya turun ke anak, anak ngelatih ke cucu itu sekarang udah banyak lagi. Banyak sanggar-sanggar baru, dan banyak kreativitasnya, entah itu dari musiknya jadi lebih modern, entah itu gerak tarinya atau segala macem, mereka bangkit lagi. 
Lampiran 5

\title{
CATATAN LAPANGAN
}

\section{LATIHAN RUTIN GAMBANG KROMONG SANGGAR SENI BETAWI SETU BABAKAN GENERASI KE-4}

\author{
Waktu : Minggu, 13 Maret 2016 pukul 08.00 \\ Lokasi : Panggung teater terbuka Perkampungan Budaya Betawi \\ Kegiatan : Observasi pengamatan dalam kegiatan latihan rutin Gambang \\ Kromong di Sanggar Seni Betawi Setu Babakan
}

\section{Deskripsi:}

Anak-anak peserta sanggar antusias datang sebelum latihan yang terjadwal dimulai pukul 08.30. Antar peserta didik berbincang akrab, begitupula dengan para orang tuanya yang saling bercakap satu sama lain sembari menunggu anaknya.

Bang Andi (pelatih) datang pukul 08.15, menyapa para peserta didik dan orangtua peserta didik sanggar, kemudian masuk ke ruang peralatan dan sound system, mengeluarkan instrumen-instrumen Gambang Kromong, dan menatanya di atas panggung dibantu peserta didiknya.

Setelah selesai loading alat, bang andi mengecek setiap instrumen Gambang Kromong tersebut dan mengkondisikan anak-anak untuk mulai latihan.

Dalam kondisi bang Andi yang sibuk mengkondisikan perlatan dan anak-anak, seorang ibu orang tua peserta didik sanggar menghampiri pemain Gambang, dan membantunya menyusun bilahan Gambang yang teracak.

Bang Andi mengecek keadaan sekali lagi, kemudian memberi kode bahwa latihan segera mulai. Latihan dimulai pukul 08.40, dimulai dengan memainkan lagu "Jali-jali". Tampak anak-anak memiliki buku repertoar lagu yang sesekali masih dilihat saat memainkan lagu.

Vokalis salah menyanyikan nada, bang Andi memberhentikan lagu, memberikan contoh kepada vokalis, dan kemudian mengulang lagu tersebut dari awal.

Pemain Gambang dan pemain Kromong juga diberikan contoh ulang agar ingat apa yang diajarkan sebelumnya. 
Latihan berlangsung santai namun serius. Lagu-lagu yang dilatih antaralain: Jali-jali, Sirih Kuning, Ondel-ondel, Sayur Asem, Eh Ujan Gerimis Aje, Indonesia Pusaka. Lagu-lagu tersebut diaransemen diantara lain pada bagian intro, interlude, dan coda.

Latihan selesai pukul 09.30, anak-anak membantu merapikan alat dan pulang, sedangkan bang Andi melanjutkan melatih tari.

\section{Refleksi:}

Pada Sanggar Seni Betawi Setu Babakan, baik itu pelatih, staff, orang tua murid, maupun peserta didik sanggar, saling berinteraksi positif, saling peduli dalam hal mendukung anak-anaknya berlatih kesenian tradisi. Hal tersebut menjadikan sanggar ini sebuah organisasi yang memiliki satu tujuan para anggotanya, yang jelas yaitu melestarikan kesenian Betawi, dan menjadikannya organisasi kesenian yang berkembang dengan baik di tengah masyarakat. Kondisi "kompak" yang ditemui antar bagian dalam Sanggar Seni Betawi Setu Babakan, sesuai dengan pernyataan Liliweri (1997:160) yang menerangkan organisasi adalah sebuah wadah, wahana, dan media perkumpulan sejumlah orang yang telah menetapkan keinginan dan kehendaknya untuk bekerja sama mencapai tujuan.

Proses penyampaian hal-hal terkait bermain musik Gambang Kromong disini, terlihat melalui tahapan diantaranya: proses melihat/mengamati, proses meniru, dan proses berlatih.

Inovasi musik Gambang Kromong tampak pada hal aransemen yang dilakukan dalam lagu-lagu yang dibawakan. Inovasi ini dilakukan dalam rangka adaptasi (adaptation). Seperti yang dinyatakan Parsons (dalam Suwarsono, 1994:11) merumuskan istilah "fungsi pokok" (fungsional imperative) untuk menggambarkan empat macam tugas yang harus dilakukan agar masyarakat tidak "mati," yang dikenal dengan sebutan AGIL (adaptation, goal attainment, integration, and latency).Adaptation sendiri adalah suatu tindakan yang ditentukan pada sub sistem sosial agar tercapai suatu tujuan, dengan demikian, adaptasi fokus pada keharusan sistem sosial untuk menghadapi lingkungan dunia seni, yaitu penyesuaian terhadap kondisi perubahan diluar 
Lampiran 6

\section{SANCGAR SENI BETAWI SETU BABAKNN}

Jl. Setu Babakan No. 35 Kel. Serengseng Sawah Kec. Jagakarsa Jakarta Selatan Telp : 021-9524 878, 081387487766

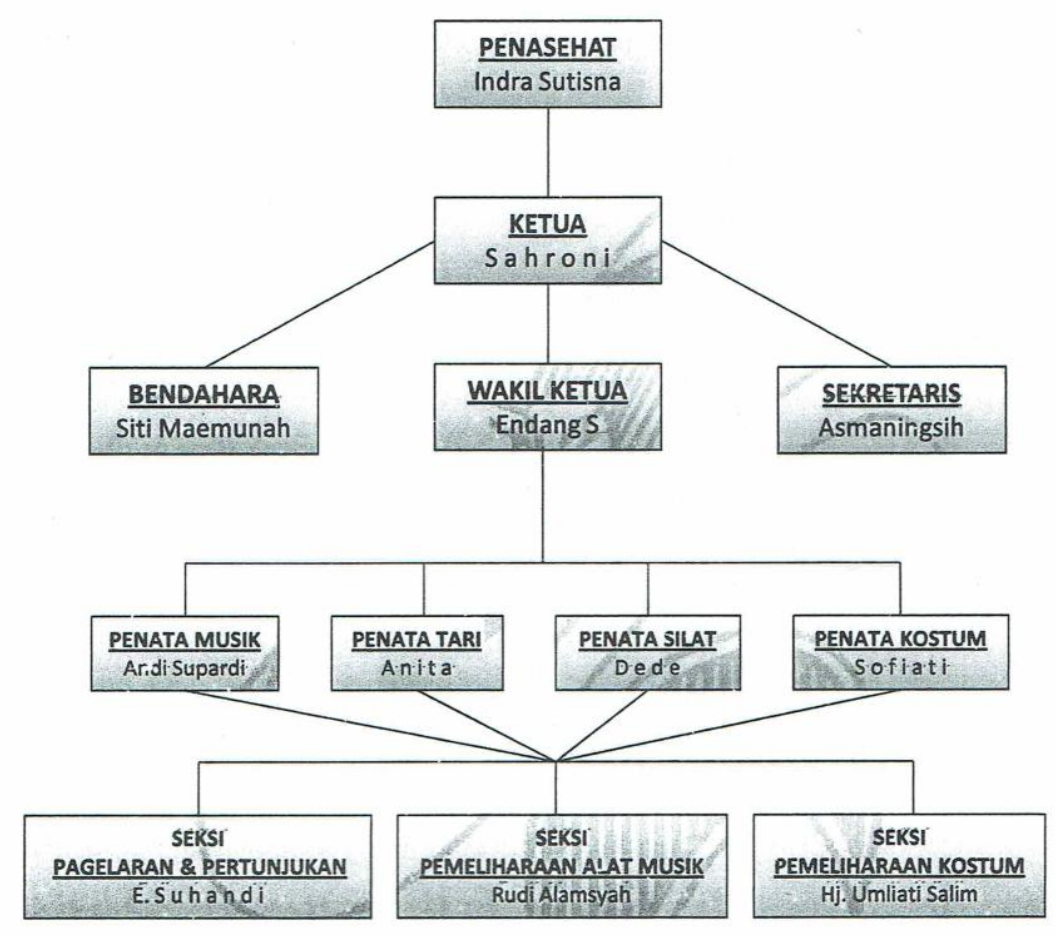




\section{Lampiran 7}

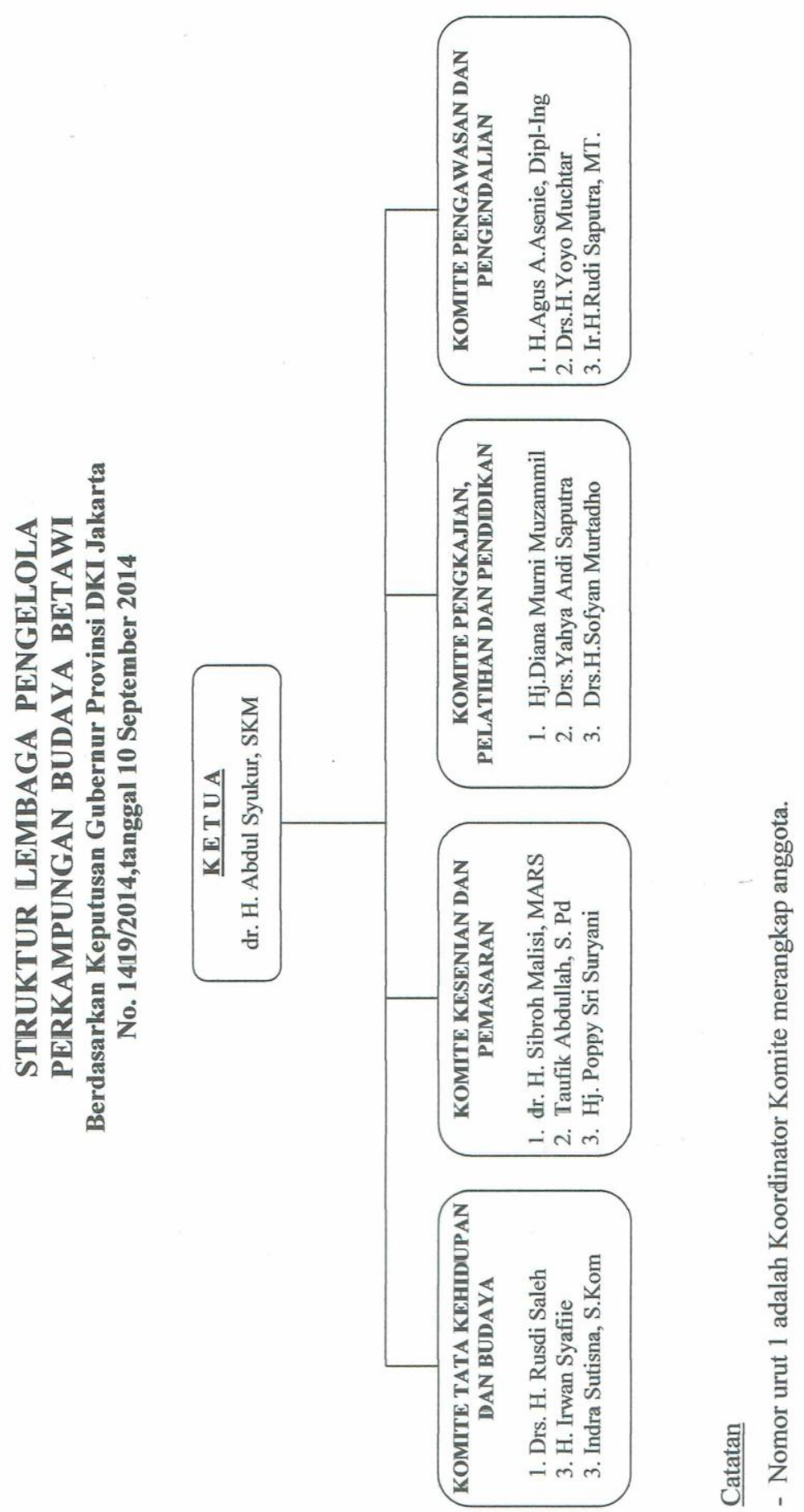


Lampiran 8

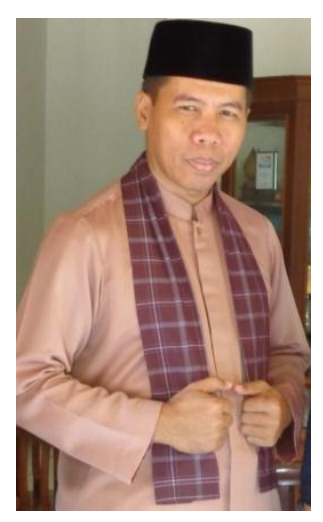

Nama $\quad$ : Indra Sutisna

Usia $\quad: 47$ tahun

Tempat Lahir: Jakarta

Tanggal Lahir: 15 Mei 1969

Alamat :Jl. Sarjana No. 17 B RT 001/09, Srengseng Sawah, Jagakarsa, Jaksel

Kedudukan : Anggota Pengelola Perkampungan Budaya Betawi

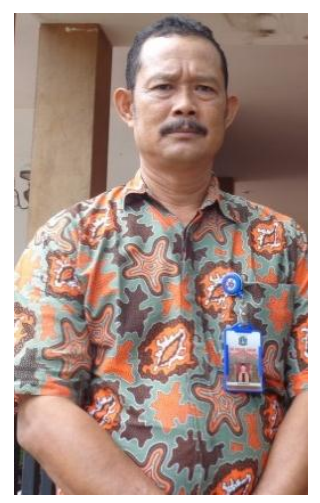

Nama $\quad$ : Sahroni

Usia : 49 tahun

Tempat Lahir: Jakarta

Tanggal Lahir: 28 Juli 1966

Alamat : Perkampungan Budaya Betawi, Jl Setu Babakan 42, RT 09 RW 08, Srengseng

Sawah, Jagakarsa, Jakarta Selatan

Kedudukan : Ketua Sanggar Seni Betawi Setu Babakan

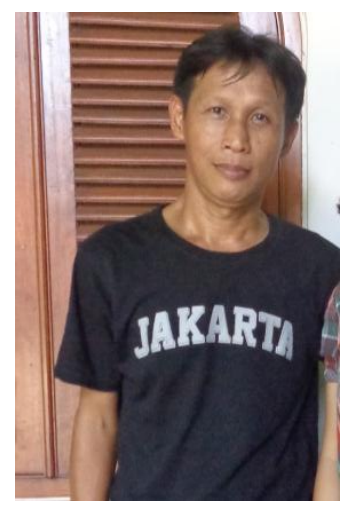

Nama : Andi Supardi

Usia $\quad: 55$ tahun

Tempat Lahir: Bogor

Tanggal Lahir: 19 September 1960

Alamat :J1 Gadok Raya, Gg Kenanga RT 06/07, Cisalak Pasar, Cimanggis, Depok

Kedudukan : Pelatih Musik dan Tari di Sanggar Seni Betawi Setu Babakan 


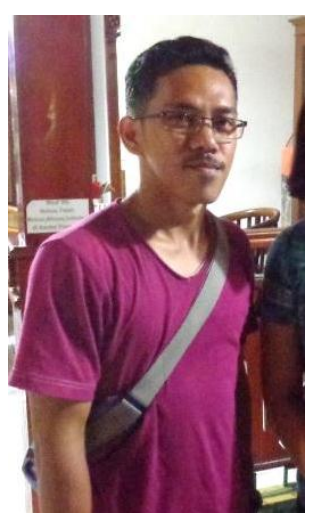

Nama : Erik Herlanda

Usia : 31 tahun

Tempat Lahir: Jakarta

Tanggal Lahir: 18 September 1985

Alamat : Jl. Setu Babakan RT 09 RW 08, Srengseng Sawah, Jagakarsa, Jakarta Selatan

Kedudukan : Pemain Tehyan Gambang Kromong 


\section{Lampiran 9}

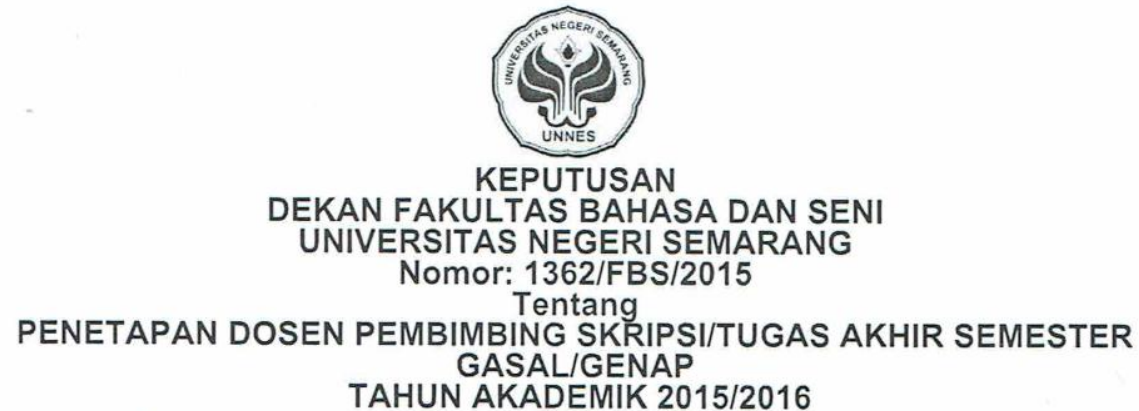

Menimbang : Bahwa untuk memperlancar mahasiswa Jurusan/Prodi Seni Drama, Tari, dan Musik/Pend. Sendratasik Fakultas Bahasa dan Seni membuat Skripsi/Tugas Akhir, maka perlu menetapkan Dosen-dosen Jurusan/Prodi Seni Drama, Tari, dan Musik/Pend. Sendratasik Fakultas Bahasa dan Seni UNNES untuk menjadi pembimbing.

Mengingat : 1. Undang-undang No.20 Tahun 2003 tentang Sistem Pendidikan Nasional (Tambahan Lembaran Negara RI No.4301, penjelasan atas Lembaran Negara RI Tahun 2003, Nomor 78)

2. Peraturan Rektor No. 21 Tahun 2011 tentang Sistem Informasi Skripsi UNNES

3. SK. Rektor UNNES No. 164/O/2004 tentang Pedoman penyusunan Skripsi/Tugas Akhir Mahasiswa Strata Satu (S1) UNNES;

4. SK Rektor UNNES No.162/O/2004 tentang penyelenggaraan Pendidikan UNNES;

Menimbang : Usulan Ketua Jurusan/Prodi Seni Drama, Tari, dan Musik/Pend. Sendratasik Tanggal 3 September 2015

Menetapkan :

\section{MEMUTUSKAN}

PERTAMA : $\quad$ Menunjuk dan menugaskan kepada:
1. Nama NIP : Prof. Dr. Totok Sumaryanto Florentinus, M.Pd.
Pangkat/Golongan : IVID
Jabatan Akademik : Guru Besar
Sebagai Pembimbing I
2. Nama :Dr. Sunarto, S.Sn., M.Hum
NIP : : 196912151999031001
Pangkat/Golongan : IVIA
Jabatan Akademik : Lektor Kepala
Sebagai Pembimbing II
Untuk membimbing mahasiswa penyusun skripsi/Tugas Akhir :

KEDUA : Keputusan ini mulai berlaku sejak tanggal ditetapkan.

Tembusan

1. Pembantu Dekan Bidang Akademik

2. Ketua Jurusan

3. Petinggal

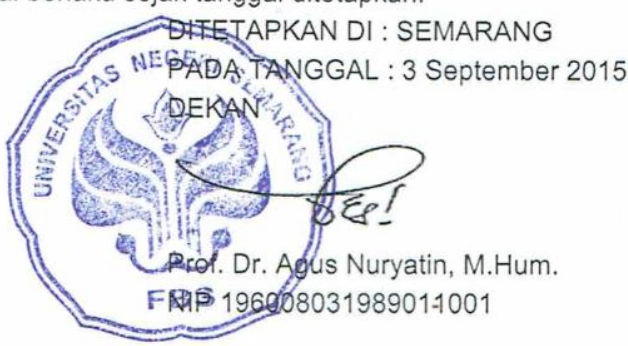

\section{|Di|l|IIIIIII||}


Lampiran 10

KEMENTERIAN RISET, TEKNOLOGI, DAN PENDIDIKAN TINGGI
UNIVERSITAS NEGERI SEMARANG
FAKULTAS BAHASA DAN SENI
$\begin{array}{r}\text { Gedung B, Kampus Sekaran, Gunungati, Semarang } 50229 \\ \text { Telepon +62248508010, Faksimile +62248508010 } \\ \text { Laman: http://fbs.unnes.ac.id, Email: fbs@unnes.ac.id }\end{array}$

Nomor : 952/UN37.1.2/LT/2016

Lamp. : -

Hal. : Permohonan Izin Penelitian

Yth. Pengelola Perkampungan Budaya Betawi Setu Babakan

di tempat

Dengan hormat kami beritahukan bahwa dalam rangka penyusunan skripsi mahasiswa kami,

nama : Marissa Renimas Harlandea

nim :2501412024

jurusan : : Pendidikan Seni Drama Tari dan Musik

program studi : Pendidikan Seni Musik

jenjang : : 1

tahun akademik $\quad: 2015 / 2016$

judul : KESENIAN GAMBANG KROMONG DI PERKAMPUNGAN BUDAYA BETAWI SETU BABAKAN JAKARTA SELATAN.

akan mengadakan penelitian di Pengelola Perkampungan Budaya Betawi Setu Babakan, waktu pelaksanaan Maret 2016 s.d. selesai. Untuk itu kami mohon Saudara berkenan memberikan izin kepada mahasiswa di atas untuk keperluan tersebut.

Atas perhatian dan kerja sama Saudara, kami sampaikan terima kasih.

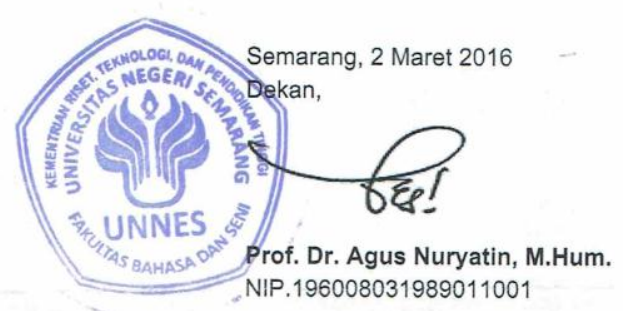

Tembusan:

1. Pembantu Dekan Bidang Akademik

2. Ketua Jurusan

3. Pertinggal 


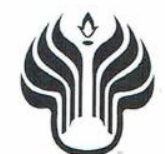

UNNES

KEMENTERIAN RISET, TEKNOLOGI, DAN PENDIDIKAN TINGGI

UNIVERSITAS NEGERI SEMARANG

FAKULTAS BAHASA DAN SENI

Gedung B, Kampus Sekaran, Gunungpati, Semarang 50229

Telepon +62248508010 , Faksimile +62248508010 Laman: http://fbs.unnes.ac.id, Email: fbs@unnes.ac.id

Nomor $:$ 952/UN37.1.2/LT/2016

Lamp. : -

Hal. : Permohonan Izin Penelitian

Yth. Sanggar Seni Betawi Setu Babakan Pimpinan Syahroni

di tempat

Dengan hormat kami beritahukan bahwa dalam rangka penyusunan skripsi mahasiswa kami,

nama : Marissa Renimas Harlandea

nim : 2501412024

jurusan $\quad$ : Pendidikan Seni Drama Tari dan Musik

program studi : Pendidikan Seni Musik

jenjang : S1

tahun akademik : $: 2015 / 2016$

judul : KESENIAN GAMBANG KROMONG DI PERKAMPUNGAN BUDAYA BETAWI SETU BABAKAN JAKARTA SELATAN

akan mengadakan penelitian di Sanggar Seni Betawi Setu Babakan Pimpinan Syahroni, waktu pelaksanaan

Maret 2016 s.d. selesai. Untuk itu kami mohon Saudara berkenan memberikan izin kepada mahasiswa di atas untuk keperluan tersebut.

Atas perhatian dan kerja sama Saudara, kami sampaikan terima kasih.

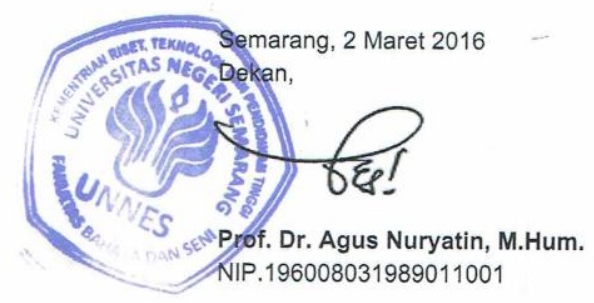

Tembusan:

1. Pembantu Dekan Bidang Akademik

2. Ketua Jurusan

3. Pertinggal 
Lampiran 11

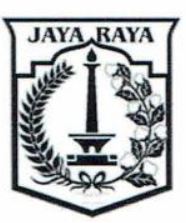

PEMERINTAH PROVINSI DAERAH KHUSUS IBUKOTA JAKARTA

DINAS PARIWISATA DAN KEBUDAYAAN

UNIT PENGELOLA KAWASAN

PERKAMPUNGAN BUDAYA BETAWI

Jalan RM. Kahfi II Telepon 021-78893373- 021 78893258, Faxsimile 021-78893258

J AKARTA

Kode Pos 12640

$\begin{array}{ll}\text { Nomor } & : \text { llu I }-072.26 \\ \text { Sifat } & : \text { Penting } \\ \text { Lampiran } & : \text { Permohonan Izin } \\ \text { Hal } & \begin{array}{l}\text { Penelitian } \\ \end{array}\end{array}$

15 Maret 2016

Kepada

Yth. Dekan Fakultas Bahasa dan Seni

Universitas Negeri Semarang

Gedung B, Kampus Sekaran, Gunungpati

di

Semarang

Sehubungan dengan surat Dekan Fakultas Bahasa dan Seni Universitas Negeri Semarang Nomor 952/UN37.1.2?LT/2016 tanggal 02 Maret 2016 perihal permohonan izin penelitian, pada prinsipnya saya tidak keberatan mengenai kegiatan dimaksud dilakukan oleh mahasiswa Fakultas Bahasa dan Seni Universitas Negeri Semarang atas nama : Marissa Renimas Harlandea, NPM : 2501412024, sepanjang berpedoman pada peraturan perundang-undangan.

Selanjutnya salinan hasil kegiatan tersebut agar diberikan juga ke Unit Pengelola Kawasan Perkampungan Budaya Betawi untuk bahan masukan bagi UKPD.

Demikian disampaikan, atas perhatiannya diucapkan terima kasih.

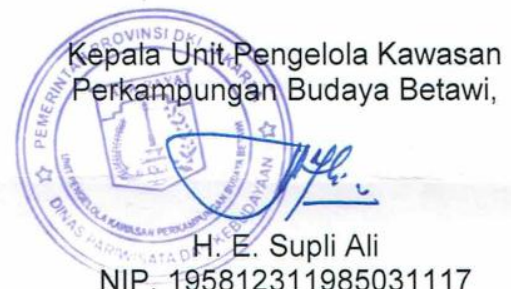

Tembusan :

1. Asisten Perekonomian Sekda Provinsi DKI Jakarta

2. Kepala Dinas Pariwisata dan Kebudayaan Prov. DKI Jakarta

3. Kepala Biro Perekonomian Setda Provinsi DKI Jakarta

4. Ketua Lembaga Pengelola PBB 